\title{
20. PLIOCENE TO PLEISTOCENE VARIATIONS IN CALCIUM CARBONATE, ORGANIC CARBON, AND OPAL ON THE OWEN RIDGE, NORTHERN ARABIAN SEA ${ }^{1}$
}

\author{
David W. Murray ${ }^{2}$ and Warren L. Prell ${ }^{2}$
}

\begin{abstract}
Site 722 provides high resolution records of percent $\mathrm{CaCO}_{3}$, magnetic susceptibility, $\delta^{18} \mathrm{O}$, organic carbon, and coarse fraction for the past 3.4 m.y. from the crest of the Owen Ridge, northwestern Arabian Sea. Within this time interval, most of the carbonate percent variations can be attributed to terrigenous dilution and do not reflect changes in the carbonate system. From the late Pliocene to Present, the average rate of calcium carbonate accumulation increases from 1 to $3 \mathrm{~g} / \mathrm{cm}^{2} / \mathrm{k}$.y. and the average accumulation of organic carbon decreases from 75 to $30 \mathrm{mg} / \mathrm{cm}^{2} / \mathrm{k}$. y. The carbonate component is more dissolved in the older interval. The long-term variations in carbonate accumulation may reflect a greater input of organic matter in the late Pliocene, which decomposes to produce $\mathrm{CO}_{2}$ and dissolve carbonate. Magnetic susceptibility and $\%$ noncarbonate $\left(100-\mathrm{CaCO}_{3} \%\right)$ reflect changes in the amount of the lithogenic component in the sediments. The period of variation of lithogenic material is the same period as the original forcing of the regional summer monsoon, however, the timing matches global aridity patterns and global ice volume (sea level) changes. This preliminary analysis suggests that the high frequency variation of lithogenic material persists for at least the last 3.4 m.y.

Within the last million years, calcium carbonate accumulation has a large amplitude signal that covaries with major changes in ice volume. Both calcium carbonate and noncarbonate (mostly terrigenous) accumulation are greatest during glacial stages. Interglacial intervals are characterized by low mass accumulation rates, increased foraminifer fragmentation, and increased opal concentration. The accumulation of organic carbon matches the high frequency changes in sedimentation rates. We attribute this high correlation to enhanced preservation of organic carbon by increased sedimentation rate. Of the three major biological components studied, only opal exhibits the variations expected for a biological productivity system forced by monsoonal upwelling driven by changes in northern hemisphere summer radiation.
\end{abstract}

\section{INTRODUCTION}

The northwestern Arabian Sea is one of the world's most productive oceanic areas. The large standing stock of plankton in this region is sustained by seasonal upwelling driven by the strong summer winds associated with the Indian Ocean summer monsoon. Recent studies of foraminifers, pollen, and windborne detritus (Prell, 1984 a, b; Prell and Van Campo, 1986; and Sirocko and Sarnthein, 1989; Clemens and Prell, 1990) indicate that the deep-sea sediments in the northwestern Arabian Sea contain both a terrestrial and oceanic record of the monsoon.

Pelagic sediments on the Owen Ridge lie beneath the area affected by monsoon-driven upwelling and should record longterm variations in the strength of the monsoon. Preliminary Leg 117 shipboard results noted a strong cyclicity in Owen Ridge sediment properties such as color, magnetic susceptibility, wetbulk density, and calcium carbonate content (Prell, Niitsuma, et al., 1989). Analysis of these data over the upper $100 \mathrm{~m}$ reveal a dominant cyclicity of about $1 \mathrm{~m}$ or about $23 \mathrm{k} . y$., the period associated with earth's precessional radiation changes. Previous studies on the large scale features of the monsoon using atmospheric circulation models (Kutzbach and Gütter, 1986; Prell and Kutzbach, 1987) indicate that variations in northern hemisphere summer insolation caused by the cyclic precession of the equinoxes are largely responsible for changes in the strength of the summer monsoon. Encouraged by these results, we examine

\footnotetext{
${ }^{1}$ Prell, W. L., Niitsuma, N., et al., 1991. Proc. ODP, Sci. Results, 117: College Station, TX (Ocean Drilling Program).

2 Department of Geological Sciences, Brown University, Providence, RI 02912,
}

the major sediment components from the Owen Ridge which are responsible for the cyclic changes in sediment properties to determine whether they record variations in the intensity of the monsoon as indicted by atmospheric circulation simulations.

During the last 3.4 m.y., Owen Ridge sediments reflect a two-component mixture of biogenic calcite and terrigenous materials. Organic matter and biogenic opal together comprise less than $5 \%$ of the sediment. Because of this, variations in the input of either calcium carbonate or terrigenous material will directly alter the percent of the other component. The terrigenous material on the Owen Ridge is largely eolian dust from nearby land areas (Sirocko and Sarnthein, 1989; Clemens and Prell, 1990; Clemens and Prell, this volume). Terrigenous input to the deep sea should be controlled by changes in wind direction and strength, and source area aridity. On the other hand, calcium carbonate is mostly derived from the shells of coccolithophores and foraminifers and its input to this supralysoclinal site should be controlled by the balance between surface water production driven by monsoon upwelling and carbonate dissolution resulting from organic matter degradation. In this study we quantify high frequency [up to $1 /(12$ k.y.)] variations in the concentration and accumulation of calcium carbonate and organic carbon during the past 3.4 m.y. and variations in opal during the past $388 \mathrm{k}$.y. to determine whether these biological components reflect variations in the intensity of the regional monsoonal upwelling. The 0-3.4 Ma time interval was chosen to include major shifts in global climate (Raymo et al, 1989; Ruddiman et al., 1989). Because terrigenous concentration variations can be inferred from the inverse of the carbonate changes, we also discuss relative changes in the terrigenous component. Clemens and Prell (this volume) provide a more detailed study of the timing of terrigenous flux and grain size variations of the terrigenous silt sized component over the past million years. 


\section{DATA AND METHODS}

Hole 722B $\left(16^{\circ} 37.3^{\prime} \mathrm{N}, 59^{\circ} 47.8^{\prime} \mathrm{E}\right.$; $2027 \mathrm{~m}$ water depth) was chosen for the construction of a composite record of sediment deposition on the Owen Ridge for the past 3.4 m.y. (Fig. 1). Compared to the other five holes drilled in the late Neogene pelagic sequence on the Ridge, Hole 722B contains the most complete record of deposition. High quality shipboard volume magnetic susceptibility (k) data measured at $5-\mathrm{cm}$ intervals provide an excellent data base for detailed hole-to-hole and site-to-site correlations (Prell, Niitsuma, et al., 1989). We use these data to construct the composite depth section for Hole 722B.

For this study, Hole $722 \mathrm{~B}$ was sampled at $20-\mathrm{cm}$ intervals in Cores $1 \mathrm{H}$ through $12 \mathrm{X}$ [0.01-105.51 meters below seafloor (mbsf)]. All samples were analyzed for calcium carbonate, organic carbon, and coarse fraction contents, as well as the isotopic composition of Globigerinoides sacculifera $(300-355 \mu \mathrm{m})$. The samples were freeze-dried and then split. Two-thirds of the dried sample was separated for faunal and isotope analysis. The remaining one-third was ground for the chemical analyses.

Calcium carbonate content was measured on a gasometric apparatus similar to that described by Jones and Kaiteris (1983).
The Brown University system uses a differential pressure gauge in place of a vacuum gauge and carbonate reactions are measured at atmospheric pressure. Replicate analyses of both samples and standards routinely give an analytical precision of better than $0.5 \%$ by weight.

Organic carbon measurements were made on a Carlo Erba NAl500 carbon analyzer after removal of calcium carbonate. We followed the technique described by Verardo et al. (1990) for removal of the inorganic carbon fraction. Dried samples were placed in aluminum sample holders and treated with sulfurous acid ( $8 \%$ reagent grade) until the reaction was complete. The residue was then measured for carbon and nitrogen. All analyses were duplicated and the differences were generally less than $5 \%$ by weight. The average values are reported in the Appendix.

Opaline silica measurements were made on 10-cm-spaced samples from nearby $15.96 \mathrm{~m}$ piston core RC27-61 $\left(16^{\circ} 39.5^{\prime} \mathrm{N}\right.$, $59^{\circ} 31.4^{\prime} \mathrm{E}$; $1893 \mathrm{~m}$ water depth) (Fig. 1). This core spans the same time interval as the top $20 \mathrm{~m}$ of Hole $722 \mathrm{~B}$. A hot $2 \mathrm{M}$ $\mathrm{Na}_{2} \mathrm{CO}_{3}$ leach was used to extract opal from the sediment samples. We used the opal extraction technique of Mortlock and Froelich (1989) except that buffered $0.5 \mathrm{M}$ acetic acid, rather than hydrochloric acid, was used to initially remove the carbon-

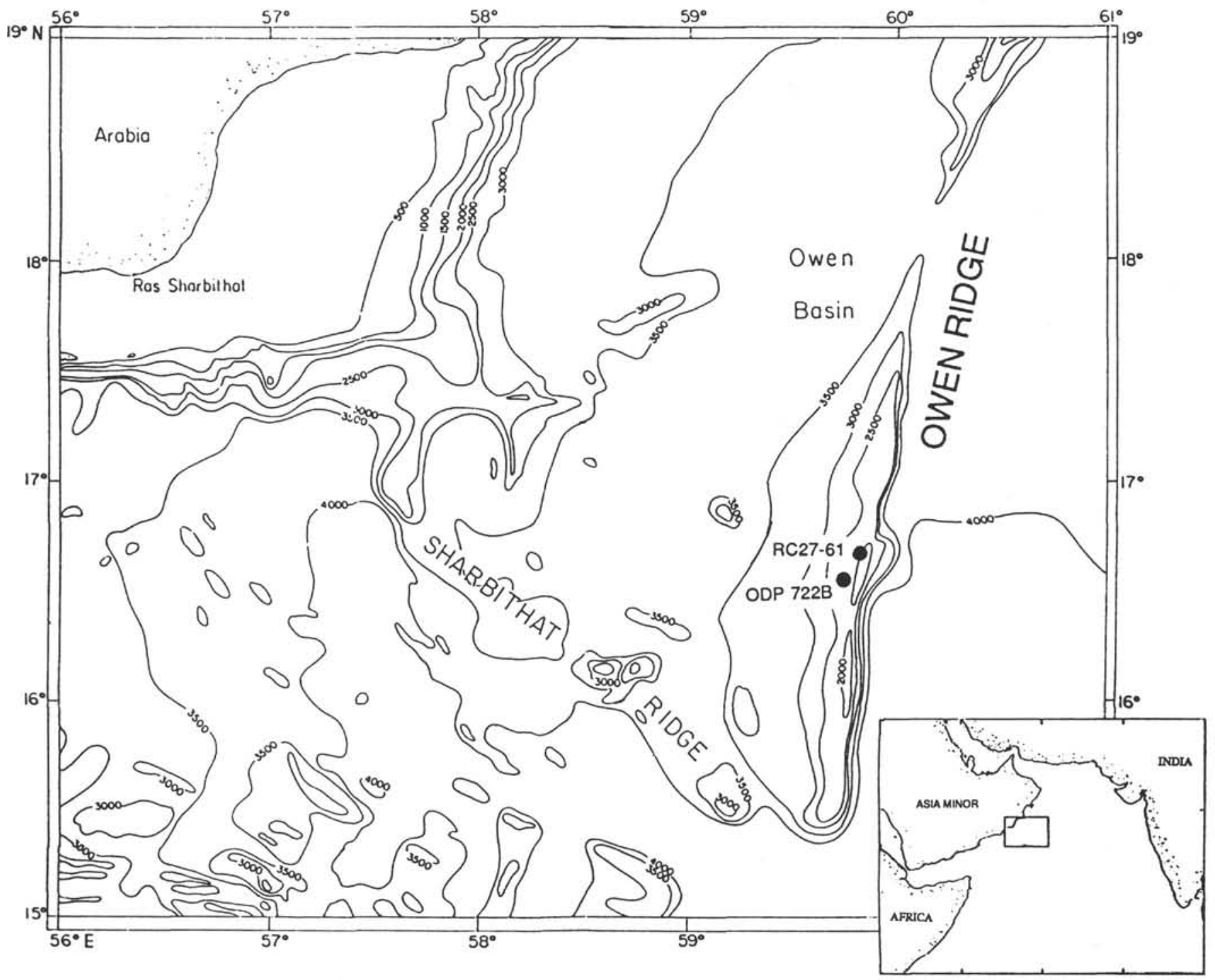

Figure 1. Bathymetric map of Leg 117 operations area and location of ODP Hole 7229 and piston core RC27-61. Contours in meters. 
ate fraction. Measurements were made on a Beckman DU spectrophotometer and the precision based on replicates was within $\pm 2 \%$.

Dry bulk density data needed to determine mass accumulation rates were derived from the shipboard GRAPE wet bulk density measurements. Hole $722 \mathrm{~A}$ shipboard GRAPE data (1.8-cm-spaced measurements) was first smoothed with a cubic spline and then sampled at depths corresponding to the discrete shipboard bulk density measurements for the top $100 \mathrm{~m}$. A linear regression based on GRAPE wet bulk density (GWBD) and discrete shipboard dry bulk density (DBD) data [DBD = $1.2664+1.3481$ (GWBD); $r=0.84$ ] was used to estimate dry bulk density values for Hole 722B samples. GRAPE values were obtained for individual samples used in this study (Appendix) by linearly interpolating between adjacent 1.8 -cm-spaced measurements. GRAPE data gaps due to coring and unmeasured short core sections were filled with data from the offset holes used to construct the composite depth model.

\section{COMPOSITE DEPTH}

The core recovery for Hole 722B was excellent within the advanced hydraulic piston cored interval from 0 to 91.9 mbsf ( $>100 \%$, Prell, Niitsuma, et al., 1989). However, with detailed hole-to-hole correlations based on magnetic susceptibility measurements, gaps as large as $1.90 \mathrm{~m}$ were recognized across core breaks. To ensure that the records were complete before analysis of the time series, we constructed a composite depth model for Hole $722 \mathrm{~B}$ by splicing in short sections from offset Holes $722 \mathrm{~A}$ and 721B. Magnetic susceptibility data sampled at 5-cm spac- ing, together with visual marker layers (Prell, Niitsuma, et al., 1989), were used to correlate the holes and recognize data gaps. Sediments in Holes 721B and 722A provided the necessary material to fill in all missing sections in Hole 722B. Two examples of the between-hole correlations and gaps at core breaks are shown in Figure 2. Based on ODP sub-bottom depths, a $40-\mathrm{cm}$ overlap in depth occurs between Cores $6 \mathrm{H}$ and $7 \mathrm{H}$ in Hole 722 B (Fig. 2A). Compared to the sediment sections cored in Holes $722 \mathrm{~A}$ and $721 \mathrm{~B}, 1.90 \mathrm{~m}$ is missing from Hole $722 \mathrm{~B}$. The interval from $51.50 \mathrm{mbsf}$ and $53.65 \mathrm{mbsf}$ in Hole 721B was spliced into the gap between Cores $6 \mathrm{H}$ and $7 \mathrm{H}$ to obtain the composite section. Similarly, $0.55 \mathrm{~m}$ from Hole $721 \mathrm{~B}$ was added to the base of Core $7 \mathrm{H}$ in Hole $722 \mathrm{~B}$ to account for the missing sediment at the break between Cores $7 \mathrm{H}$ and $8 \mathrm{H}$ (Fig. 2B).

The composite depth model for Hole 722B was constructed by assigning the sediment-water interface a depth of 0 mbsf and successively adding each spliced sediment section down through the sediment column (Table 1). This follows the approach of Ruddiman et al. (1989) in their construction of a composite depth model for DSDP Sites 607 and 609. However, this technique violates the original ODP shipboard depths by continuously adding to the reported sub-bottom core depth. A potential problem is apparent in Figure 2B where the resulting sub-bottom depth in the composite depth model is substantially greater than the true depth below seafloor. The increase in magnetic susceptibility near $66 \mathrm{mbsf}$ in Hole $722 \mathrm{~B}$ is within $0.5 \mathrm{~m}$ of depth below seafloor for this event in the other two holes. However, in the composite depth model, the new depth of this event is almost $3.5 \mathrm{~m}$ greater. A total of $5.80 \mathrm{~m}$ was added to the top

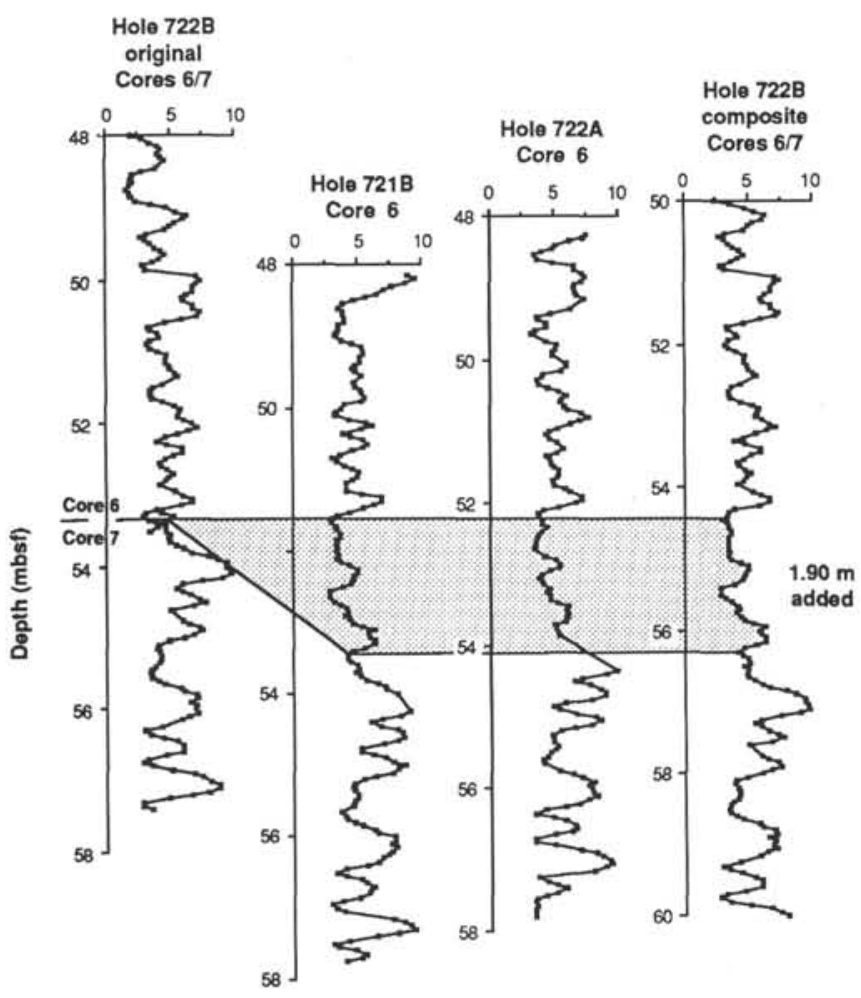

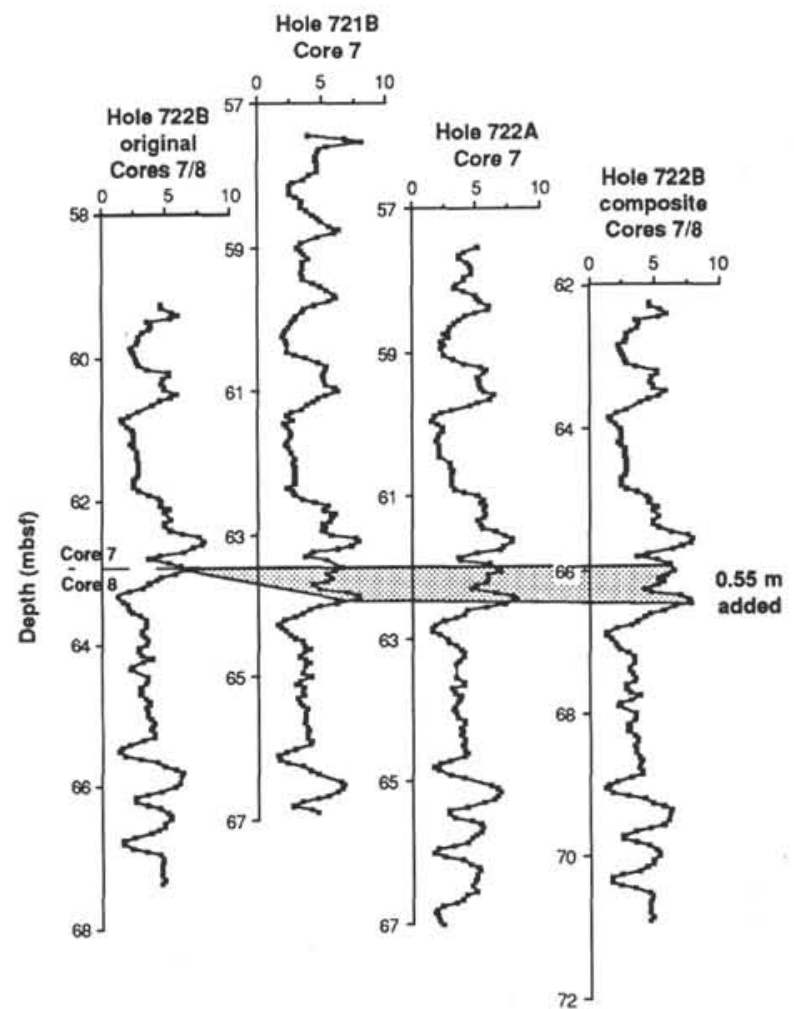

B

Figure 2. Hole-to-hole correlation and composite volume magnetic susceptibility $\left(10^{-6} \mathrm{cgs}\right)$ record for the gaps between (A) Cores 6 and 7 and (B) Cores 7 and 8 in Hole 722B. The shaded portion in each diagram indicates the sedimentary section missing from Hole $722 \mathrm{~B}$ that is added to the composite depth model. 
Table 1. Composite depth model for Hole 722B.

\begin{tabular}{|c|c|c|c|c|c|}
\hline \multirow[b]{2}{*}{ From sample } & \multirow[b]{2}{*}{ To sample } & \multicolumn{2}{|c|}{$\begin{array}{c}\text { Original } \\
\text { depth } \\
\text { (mbsf) }\end{array}$} & \multicolumn{2}{|c|}{$\begin{array}{c}\text { Composite } \\
\text { depth } \\
\text { (mbsf) }\end{array}$} \\
\hline & & From & To & From & To \\
\hline $722 \mathrm{~B}-1 \mathrm{H}-1,1 \mathrm{~cm}$ & $1 \mathrm{H}-4,19 \mathrm{~cm}$ & 0.01 & 5.19 & 0.01 & 5.19 \\
\hline $722 \mathrm{~A}-1 \mathrm{H}-3,80 \mathrm{~cm}$ & $1 \mathrm{H}-3,130 \mathrm{~cm}$ & 3.80 & 4.30 & 5.20 & 5.70 \\
\hline $722 \mathrm{~B}-2 \mathrm{H}-1,21 \mathrm{~cm}$ & $2 \mathrm{H}-7,9 \mathrm{~cm}$ & 5.71 & 14.59 & 5.71 & 14.59 \\
\hline $722 \mathrm{~A}-2 \mathrm{H}-3,90 \mathrm{~cm}$ & $2 \mathrm{H}-4,34 \mathrm{~cm}$ & 13.70 & 14.64 & 14.60 & 15.54 \\
\hline $722 \mathrm{~B}-3 \mathrm{H}-1,45 \mathrm{~cm}$ & $3 \mathrm{H}-7,54 \mathrm{~cm}$ & 15.45 & 24.64 & 15.55 & 24.74 \\
\hline $721 \mathrm{~B}-3 \mathrm{H}-4,25 \mathrm{~cm}$ & $3 \mathrm{H}-4,130 \mathrm{~cm}$ & 23.85 & 24.90 & 24.75 & 25.80 \\
\hline $722 \mathrm{~B}-4 \mathrm{H}-1,86 \mathrm{~cm}$ & $5 \mathrm{H}-7,59 \mathrm{~cm}$ & 25.56 & 43.89 & 25.81 & 44.14 \\
\hline $721 \mathrm{~B}-5 \mathrm{H}-3,30 \mathrm{~cm}$ & $5 \mathrm{H}-3,120 \mathrm{~cm}$ & 41.80 & 42.70 & 44.15 & 45.05 \\
\hline $722 \mathrm{~B}-6 \mathrm{H}-1,6 \mathrm{~cm}$ & $6 \mathrm{H}-7,34 \mathrm{~cm}$ & 43.96 & 53.24 & 45.06 & 54.34 \\
\hline $721 \mathrm{~B}-6 \mathrm{H}-3,40 \mathrm{~cm}$ & $6 \mathrm{H}-4,105 \mathrm{~cm}$ & 51.50 & 53.65 & 54.35 & 56.45 \\
\hline $722 \mathrm{~B}-7 \mathrm{H}-1,26 \mathrm{~cm}$ & $7 \mathrm{H}-3,150 \mathrm{~cm}$ & 53.46 & 57.65 & 56.46 & 60.70 \\
\hline${ }^{a} 721 B-H-1,75 \mathrm{~cm}$ & $7 \mathrm{H}-2,60 \mathrm{~cm}$ & 58.15 & 59.50 & 60.85 & 62.20 \\
\hline 722B-7H-5, $1 \mathrm{~cm}$ & $7 \mathrm{H}-7,70 \mathrm{~cm}$ & 59.25 & 62.90 & 62.21 & 65.90 \\
\hline $721 \mathrm{~B}-7 \mathrm{H}-4,146 \mathrm{~cm}$ & $7 \mathrm{H}-5,54 \mathrm{~cm}$ & 63.36 & 63.94 & 65.91 & 66.49 \\
\hline 722B-8H-1, $5 \mathrm{~cm}$ & $8 \mathrm{H}-7,64 \mathrm{~cm}$ & 62.95 & 72.54 & 66.50 & 76.09 \\
\hline $721 \mathrm{~B}-8 \mathrm{H}-4,130 \mathrm{~cm}$ & $8 \mathrm{H}-5,55 \mathrm{~cm}$ & 72.70 & 73.45 & 76.10 & 76.85 \\
\hline $722 \mathrm{~B}-9 \mathrm{H}-1,11 \mathrm{~cm}$ & $9 \mathrm{H}-7,79 \mathrm{~cm}$ & 72.61 & 82.29 & 76.86 & 86.54 \\
\hline $721 \mathrm{~B}-9 \mathrm{H}-5,80 \mathrm{~cm}$ & $9 \mathrm{H}-6,45 \mathrm{~cm}$ & 83.20 & 84.35 & 86.55 & 87.70 \\
\hline $722 \mathrm{~B}-10 \mathrm{H}-1,11 \mathrm{~cm}$ & $10 \mathrm{H}-7,69 \mathrm{~cm}$ & 82.81 & 92.39 & 87.71 & 97.29 \\
\hline $721 \mathrm{~B}-10 \mathrm{X} 6,20 \mathrm{~cm}$ & $10 \mathrm{X}-6,110 \mathrm{~cm}$ & 94.20 & 94.60 & 97.30 & 97.70 \\
\hline $722 \mathrm{~A}-10 \mathrm{X}-3,90 \mathrm{~cm}$ & $10 X-4,90 \mathrm{~cm}$ & 90.40 & 91.90 & 97.75 & 99.25 \\
\hline $722 \mathrm{~B}-11 \mathrm{X}-2,31 \mathrm{~cm}$ & $11 X-4,119 \mathrm{~cm}$ & 93.71 & 97.59 & 99.26 & 103.14 \\
\hline $721 \mathrm{~B}-11 \mathrm{X}-4,70 \mathrm{~cm}$ & $11 X-6,20 \mathrm{~cm}$ & 100.80 & 103.30 & 103.15 & 105.65 \\
\hline $722 \mathrm{~A}-11 \mathrm{X}-3,40 \mathrm{~cm}$ & $11 X-4,145 \mathrm{~cm}$ & 99.60 & 102.15 & 105.70 & 108.25 \\
\hline $722 \mathrm{~B}-12 \mathrm{X}-1,96 \mathrm{~cm}$ & $12 \mathrm{X}-3,105 \mathrm{~cm}$ & 102.46 & 105.55 & 108.26 & 111.35 \\
\hline
\end{tabular}

${ }^{a}$ No magnetic susceptibility data available for Section $722 \mathrm{~B}-7 \mathrm{H}-4$.

of Core $12 \mathrm{X}$ because of material spliced in at core breaks in the preceding intervals. Alternatively, we could have preserved the original depths of each core and linearly squeezed the composite section to fit within the reported ODP core length. This is much more difficult to document and causes a nonuniform adjustment of sub-bottom depth for individual sediment samples. Our composite depth reconstruction for Hole 722B Cores $1 \mathrm{H}$ through $12 \mathrm{X}$ is documented in Figure 3 and Table 1. The sediment thickness added at each core break are listed in Table 2, and composite depths for individual samples are listed in the Appendix.

The magnetic susceptibility values assigned to the individual samples used in this study were obtained by linearly interpolating between the 5-cm-spaced measurements of the composite record. As shown in Figure 3, the 20-cm-spaced interpolated record preserves most of the structure of the original signal. Therefore, our 20 -cm samples should record the major changes in sediment properties over the interval studied. The interpolated magnetic susceptibility and the noncarbonate portion of the sediment are highly correlated (Fig. 4). We use this relationship to fill in $\mathrm{CaCO}_{3} \%$ data gaps at core breaks in the composite record of Site 722. A regression between carbonate and magnetic susceptibility with 10 samples above and 10 below each data gap was used to obtain the carbonate values needed for the composite record. This provides a continuous record of the relative changes between calcium carbonate and noncarbonate (terrigenous material) on the Owen Ridge for the past 3.4 m.y. A major shift in the mean variation of magnetic susceptibility is observed near $6.60 \mathrm{mbsf}$; values from 0 to $6.60 \mathrm{mbsf}$ average $9.97 \times 10^{-6} \mathrm{cgs}$ while values from 6.60 to $105.5 \mathrm{mbsf}$ average $3.69 \times 10^{-6} \mathrm{cgs}$. This shift, which reflects a relative increase in concentration or size of the magnetic minerals in the Hole $722 \mathrm{~B}$ sediments since $150 \mathrm{k} . \mathrm{y}$., is not observed in the calcium carbonate concentration data. To avoid the influence of this shift in calculating values for the composite record, we used a regression based on six samples above and below the gap between Cores 1 and 2 to obtain the $\mathrm{CaCO}_{3} \%$ value at $5.54 \mathrm{~m}$. Composite records of magnetic susceptibility, noncarbonate, and dry bulk density are shown in Figure 5 and listed in the Appendix. As noted earlier, the density values were obtained from interpolated GRAPE data using sections from offset holes to fill data gaps.

\section{AGE MODEL}

Shipboard magnetic-reversal stratigraphy was used to provide a preliminary age model for the past $3.4 \mathrm{~m}$.y. of Hole 722B (Table 3). With the exception of the upper limit of Discoaster pentaradiatus $(2.40 \mathrm{Ma})$, the nannofossil datums used to determine accumulation rates for the Leg 117 Initial Reports (Prell, Niitsuma, et al., 1989) lie along the linear rates between magnetic events (Fig. 6A). This coarse resolution age model provides mean sedimentation rates covering approximately $1 \mathrm{~m} . \mathrm{y}$. intervals. In Hole 722B, these rates range from $23 \mathrm{~m} / \mathrm{m}$.y. for 2.5-3.4 Ma to $41 \mathrm{~m} / \mathrm{m}$.y. for 0-1 Ma.

Oxygen isotope stratigraphy has been used routinely to correlate cores from different oceanic environments and place them in a common chronostratigraphic framework (Imbrie et al., 1984). Compared to oxygen isotopic records from other oceanic areas with relatively constant sedimentation rates (Imbrie et al., 1984), glacial intervals in Hole 722 B are expanded and interglacials are compressed. This indicates that the assumption of a constant sedimentation rate between successive magnetic datums is not valid for Owen Ridge sediments and a higher resolution age model is necessary to accurately record temporal changes in the input of major sedimentary components. Oxygen isotope stratigraphy was used to construct a high resolution age model for Hole 722B from 0 to $1 \mathrm{Ma}$ (Clemens and Prell, this volume). This model relies on ages assigned to oxygen isotope events in the SPECMAP stack (Imbrie et al., 1984) for the last 780 k.y. and the tuned stratigraphy of Ruddiman et al. (1989) between 780 and 1000 k.y. We assume a linear sedimentation rate between 50 identified isotope events to derive ages for individual samples. The age-depth plot in Figure 6B show the differences between the two age models for the $0-1 \mathrm{Ma}$ time interval. Differences of more than 60,000 yr are evident below 20 mbsf. The major disparities between the age models and with respect to the chronology of the SPECMAP stack as shown in Figure 7. Note that for the assumption of constant sedimentation to be valid glacial stages would have to span a longer time interval compared to interglacial stages. The adjustments made by the correlation to the SPECMAP stack requires sedimentation rate to be greater in the glacial stages compared to interglacials. Sedimentation rates (S) for the individual samples (i) were derived from the difference in age $(\mathrm{T})$ and depth (D) of adjacent samples: $\mathrm{S}_{\mathrm{i}}=\left(\mathrm{D}_{\mathrm{i}+1}-\mathrm{D}_{\mathrm{i}-1}\right) /\left(\mathrm{T}_{\mathrm{i}+1}-\mathrm{T}_{\mathrm{i}-1}\right)$.

\section{RESULTS}

Calcium carbonate is the dominant sediment component at Site 722, accounting for $66 \mathrm{wt} \%$ of the sediments during the past $3.4 \mathrm{~m}$.y. In general, interglacial periods are carbonate-rich and glacial stages are carbonate-poor. The $\mathrm{CaCO}_{3} \%$ and interpolated magnetic susceptibility data exhibit the same scale of variation but are inverse (Fig. 4). This implies that magnetic susceptibility accurately records variations in the noncarbonate component (mostly terrigenous material). We express the calcium carbonate variations in terms of mass accumulation (MAR) to remove the affect of terrigenous dilution; where $\operatorname{MAR}\left(\mathrm{g} / \mathrm{cm}^{2} / \mathrm{k}\right.$.y.) $=$ concentration $(\mathrm{g} / \mathrm{g}) \times$ sedimentation rate $(\mathrm{cm} / \mathrm{k} . \mathrm{y}$.$) \times dry$ bulk density $\left(\mathrm{g} / \mathrm{cm}^{3}\right)$. High resolution sedimentation rates in Hole $722 \mathrm{~B}$ are required to quantify high frequency changes in accumulation rate (Fig. 7). Otherwise, a constant sedimentation rate applied to million-year intervals in Hole $722 \mathrm{~B}$ only captures the changes in accumulation rate at periods longer than $1 \mathrm{~m} . \mathrm{y}$. Calcium carbonate accumulation, as quantified with the high resolution oxygen isotope age model, varies from about 1 to 6 $\mathrm{g} / \mathrm{cm}^{2} / \mathrm{k}$.y. over the past $1 \mathrm{~m}$.y. These changes are out of phase 


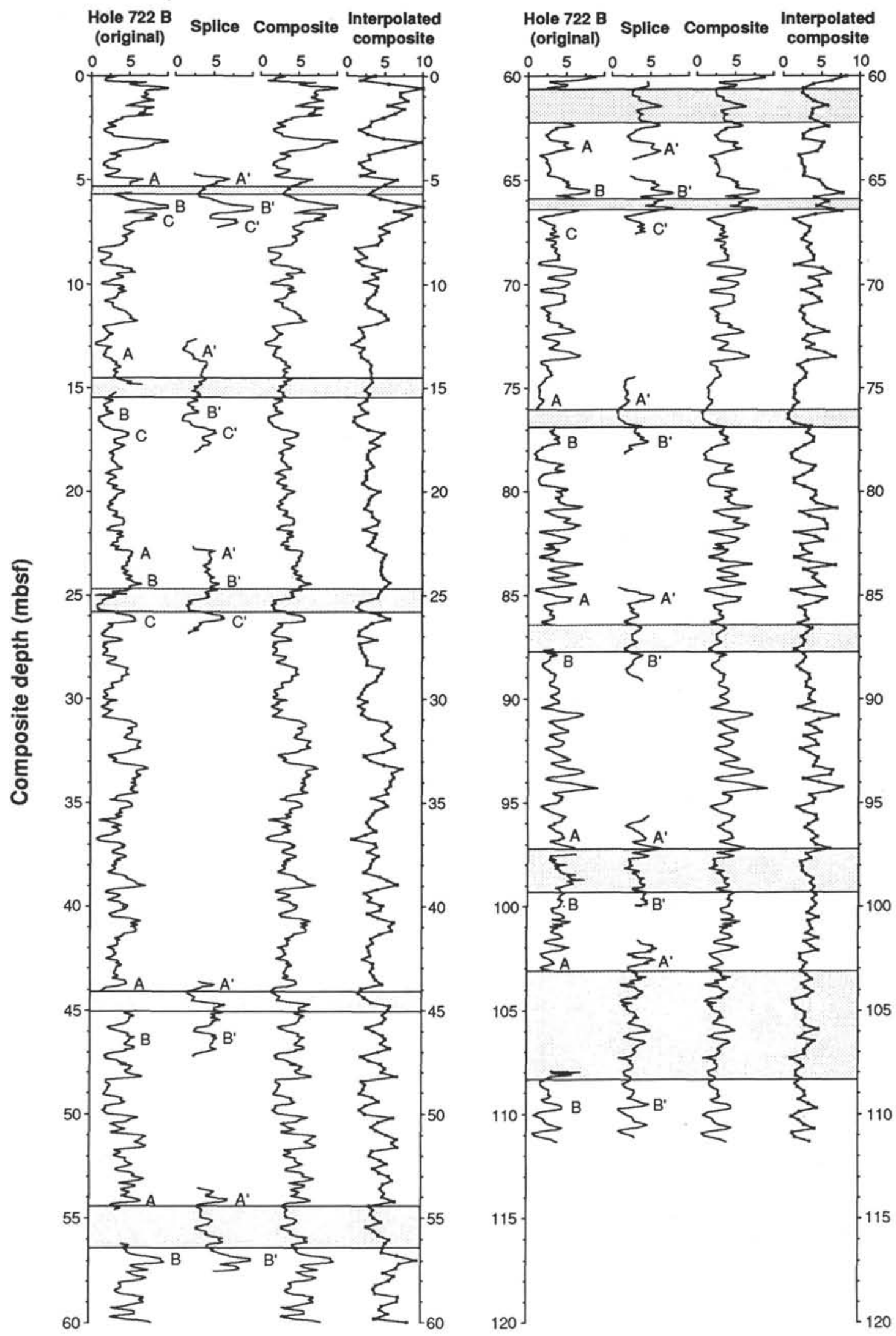

Figure 3. Hole 722B original and composite volume magnetic susceptibility $\left(10^{-6} \mathrm{cgs}\right)$ records for Cores $1 \mathrm{H}-12 \mathrm{X}$. Spliced sections used to fill data gaps and suspect intervals (shaded) were obtained from offset Holes 722A and 721B. Magnetic susceptibility data interpolated at depths corresponding to samples analyzed in this study $(\sim 20-\mathrm{cm}$ intervals) is shown. 
Table 2. Adjusted core-top depths for Hole $722 B$.

\begin{tabular}{lrrrr}
\hline & $\begin{array}{r}\text { ODP } \\
\text { depth } \\
\text { (mbsf) }\end{array}$ & $\begin{array}{c}\text { Composite } \\
\text { depth } \\
\text { (mbsf) }\end{array}$ & $\begin{array}{c}\text { Added } \\
\text { depth } \\
\text { (m) }\end{array}$ & $\begin{array}{c}\text { Shipboard } \\
\text { corrected } \\
\text { depth } \\
\text { (mbsf) }\end{array}$ \\
\hline $1 \mathrm{H}$ & 0.00 & 0.00 & - & 0.00 \\
$2 \mathrm{H}$ & 5.51 & 5.51 & 0.00 & 5.80 \\
$3 \mathrm{H}$ & 15.10 & 15.10 & 0.00 & 15.40 \\
$4 \mathrm{H}$ & 24.70 & 24.95 & 0.25 & 25.50 \\
$5 \mathrm{H}$ & 34.30 & 34.55 & 0.00 & 35.30 \\
$6 \mathrm{H}$ & 43.90 & 45.00 & 0.85 & 45.00 \\
$7 \mathrm{H}$ & 53.20 & 56.20 & 1.90 & 55.60 \\
$8 \mathrm{H}$ & 62.90 & 66.45 & 0.55 & 65.50 \\
$9 \mathrm{H}$ & 72.50 & 76.75 & 0.70 & 75.50 \\
$10 \mathrm{H}$ & 82.70 & 87.60 & 0.65 & 84.30 \\
$11 \mathrm{X}$ & 91.90 & 97.45 & 0.65 & 94.10 \\
$12 \mathrm{X}$ & 101.50 & 107.30 & 0.25 & 103.60 \\
\hline
\end{tabular}

${ }^{\text {a }}$ From Shipboard Scientific Party (1989, Table 14).

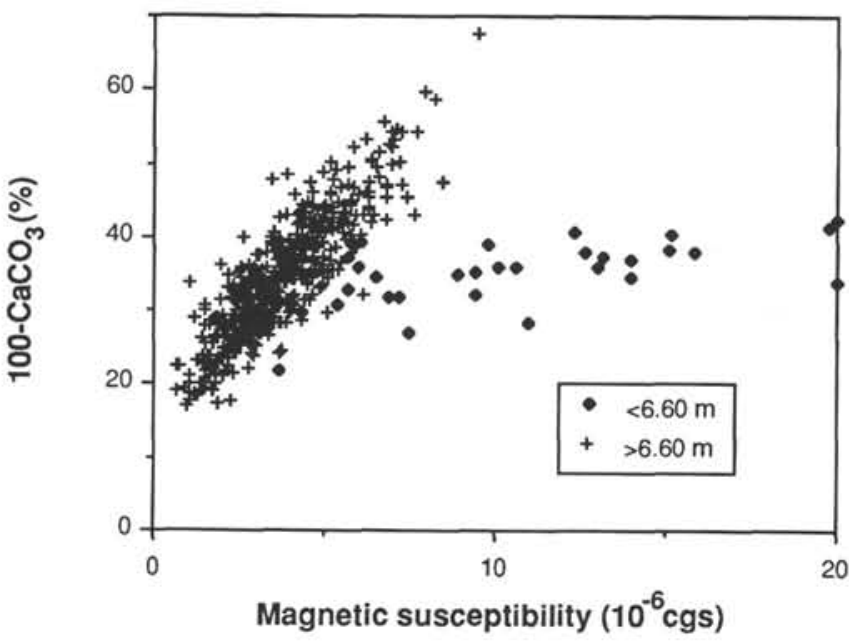

Figure 4. Noncarbonate percent vs. interpolated magnetic susceptibility for Cores $1 \mathrm{H}-12 \mathrm{X}$ in Hole $722 \mathrm{~B}$. The division at $6.60 \mathrm{~m}$ reflects a shift in the mean magnetic susceptibility values that is not observed in the $\mathrm{CaCO}_{3} \%$ data.

with the carbonate percent variations. In fact, the $434,000-y r$ record from nearby piston core RC27-61 shows that high carbonate concentrations associated with interglacial stages correspond to intervals with substantially larger numbers of planktonic foraminifer fragments and lower carbonate accumulation rates as compared to glacial intervals (Fig. 8). These results indicate that the carbonate-rich interglacial intervals are more dissolved than the glacial-aged intervals characterized by lower $\mathrm{CaCO}_{3} \%$. Since the site is well above the lysocline, this dissolution may be driven by the degradation of organic matter. Much of the percent variation is due simply to terrigenous dilution, so $\mathrm{CaCO}_{3} \%$ is not an accurate monitor of the carbonate system at this site. However, the noncarbonate concentration record, which is highly correlated to magnetic susceptibility, provides a reliable monitor of the timing of the input and accumulation of terrigenous material; i.e., greater terrigenous accumulation during glacial stages (Clemens and Prell, this volume).

Opal and organic carbon are only minor components of the Owen Ridge sediments. During the past $388,000 \mathrm{yr}$, opal varies from about $0.5 \%$ to $2.5 \%$ and distinct maxima occur within interglacial stages (Fig. 8). Radiolarian shells are the dominant siliceous component in these sediments and diatom remains are

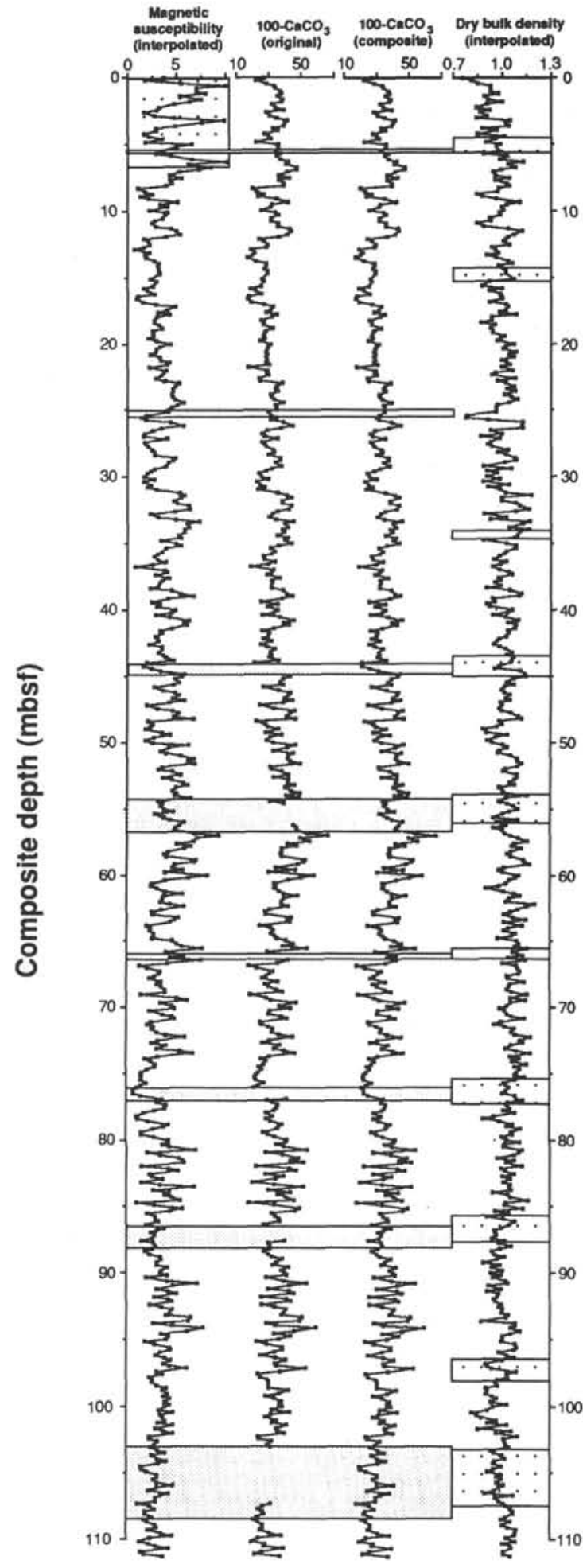

Figure 5. Interpolated magnetic susceptibility $\left(10^{-6} \mathrm{cgs}\right)$, measured and composite noncarbonate percent, and interpolated dry bulk density (g/ $\mathrm{cm}^{3}$ ) vs. composite depth for Hole 722B. Shaded intervals indicate data gaps and suspect values where composite noncarbonate values were obtained from a regression between noncarbonate and interpolated magnetic susceptibility data. Magnetic susceptibility data highlighted with the dotted pattern have been divided by two to account for the shift in magnitude near $6.60 \mathrm{~m}$. Spliced dry bulk density data from offset holes are indicated with a dotted pattern. 
Table 3. Magnetic and nannofossil datums for Hole $722 B$.

\begin{tabular}{lcc}
\hline \multicolumn{1}{c}{ Event $^{\mathrm{a}}$} & $\begin{array}{c}\text { Age } \\
\text { (m.y.) }\end{array}$ & $\begin{array}{c}\text { Composite depth } \\
\text { (mbsf) }\end{array}$ \\
\hline B Emiliania huxleyi & 0.19 & 7.95 \\
T Pseudoemiliania lacunosa & 0.49 & 18.90 \\
T Reticulofenestra sp. A & 0.82 & 34.65 \\
B Jaramillo & 0.98 & 40.35 \\
T Calcidiscus macintyrei & 1.45 & 55.55 \\
T Discoaster brouweri & 1.90 & 69.50 \\
T Discoaster pentaradiatus & 2.40 & 80.05 \\
Matuyama/Gauss & 2.47 & 89.40 \\
Gauss/Gilbert & 3.40 & 110.80 \\
\hline
\end{tabular}

a From Shipboard Scientific Party (1989, Tables 4 and 7).

b The hole-to-hole correlation based on magnetic susceptibility was used to obtain Hole 722B composite depths for the nannofossil datums that were originally identified in Hole 722A.

only present in the intervals of highest opal concentrations. The measured opal concentrations within Stage 5 are lower than other interglacial stages. This interval corresponds to large numbers $\left(1.8 \times 10^{4} / \mathrm{g}\right)$ of radiolarian shells but no diatoms. The low opal values may be due, in part, to incomplete digestion of the more resistant radiolarian opal by the $\mathrm{Na}_{2} \mathrm{CO}_{3}$ leach. The opal\% variations in RC27-61 are of similar amplitude and are coincident with variations of $\mathrm{Si} / \mathrm{Al}$ from Hole 722B (Schimmeld et al., this volume). This similarity indicates that opal accounts most of the $\mathrm{Si}$ in excess of that associated with the detrital alu- minosilicate component. Opal accumulation in core RC27-61 generally exhibits the same temporal pattern as the concentration data (Fig. 8). The average rate of accumulation (19 mg/ $\mathrm{cm}^{2} / \mathrm{k}$.y.) for the past $388 \mathrm{k} . \mathrm{y}$. is close to that measured in low accumulation rate sediments beneath the eastern equatorial $\mathrm{Pa}$ cific zone of high productivity (Fischer et al., 1986). We note, however, that the opal accumulation rates on the Owen Ridge are characteristically low for sites with high surface productivity and sedimentation rates of $3-4 \mathrm{~cm} / \mathrm{k} . \mathrm{y}$.

Organic carbon concentration varies from $0.4 \%$ to $2.0 \%$ over the past $1 \mathrm{~m} . y$. Preliminary shipboard results indicate that much of the recent organic matter accumulating on the Owen Ridge is of marine origin (Prell, Niitsuma, et al., 1989). Organic carbon accumulation varies from 10.0 to $155 \mathrm{mg} / \mathrm{cm}^{2} / \mathrm{k}$.y. with a mean of $46 \mathrm{mg} / \mathrm{cm}^{2} / \mathrm{k}$.y. for the past $1 \mathrm{~m} . \mathrm{y}$. (Fig. 7). This burial rate is significantly higher than that commonly associated with pelagic carbonates and is comparable to mid-water sites on the northwest African and Peru margins (Sarnthein et al., 1989). Glacial intervals are periods of enhanced organic carbon accumulation, greater sedimentation rates, but weaker monsoons. If the amount of organic carbon production is associated with monsoon-driven upwelling then our data suggest that much of the variation in organic carbon accumulation over the last 1 m.y. can be attributed to sedimentation rate enhanced preservation and does not reflect changes in the primary input of organic carbon to the sediments.

The long-term variations in calcium carbonate and organic carbon accumulation, and coarse fraction percent (mostly shells of foraminifers) are shown in Figure 9. We also show the high
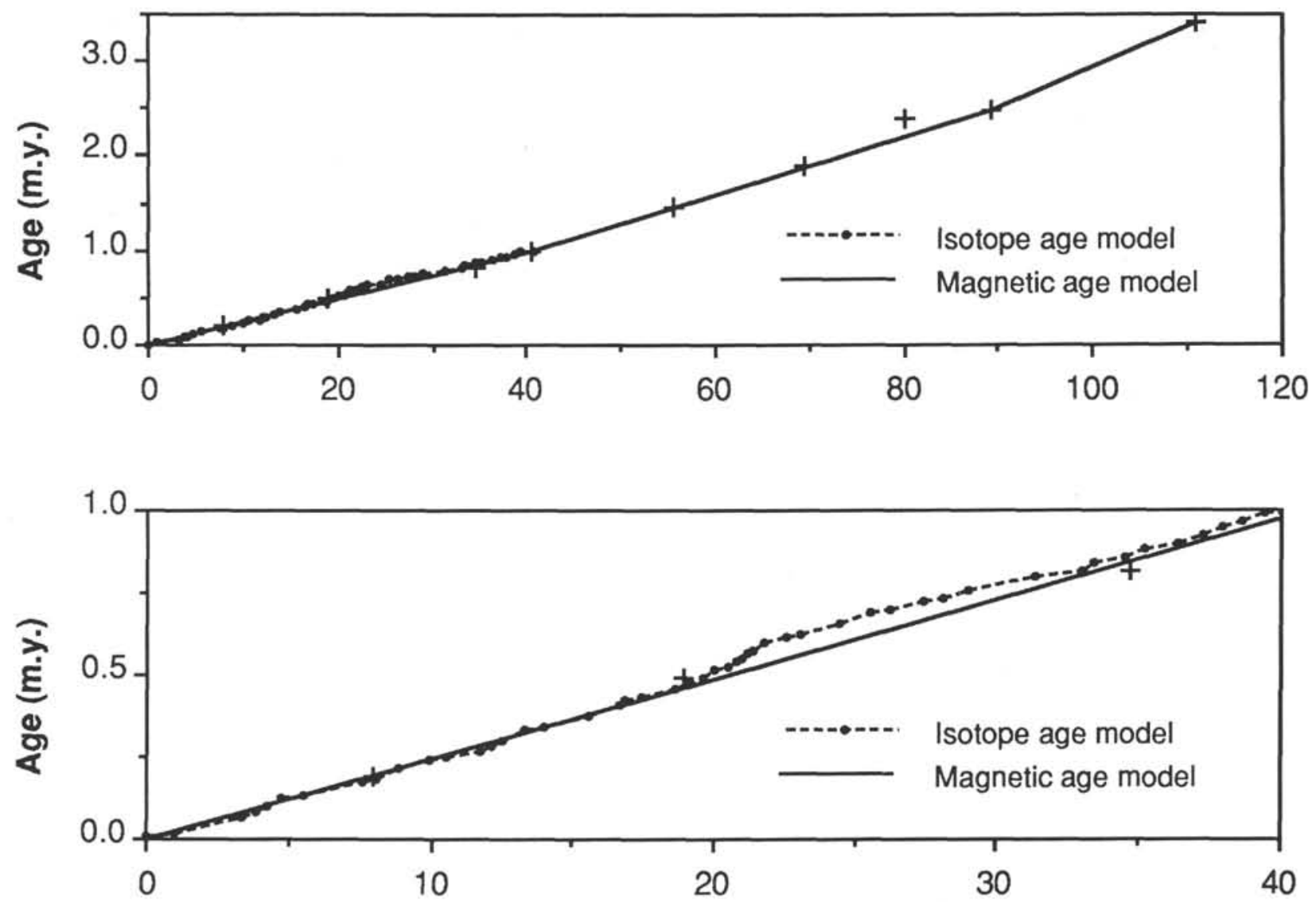

Figure 6. Age vs. depth plots for Hole 722B for 0-120 m (Cores $1 \mathrm{H}-12 \mathrm{X}$ ) (top) and 0-40 m (bottom). Pluses are the nannofossil and magnetic reversal datums listed in Table 3. Solid circles are the 50 events used to construct the oxygen isotope-based chronology. See text for discussion of age models. 


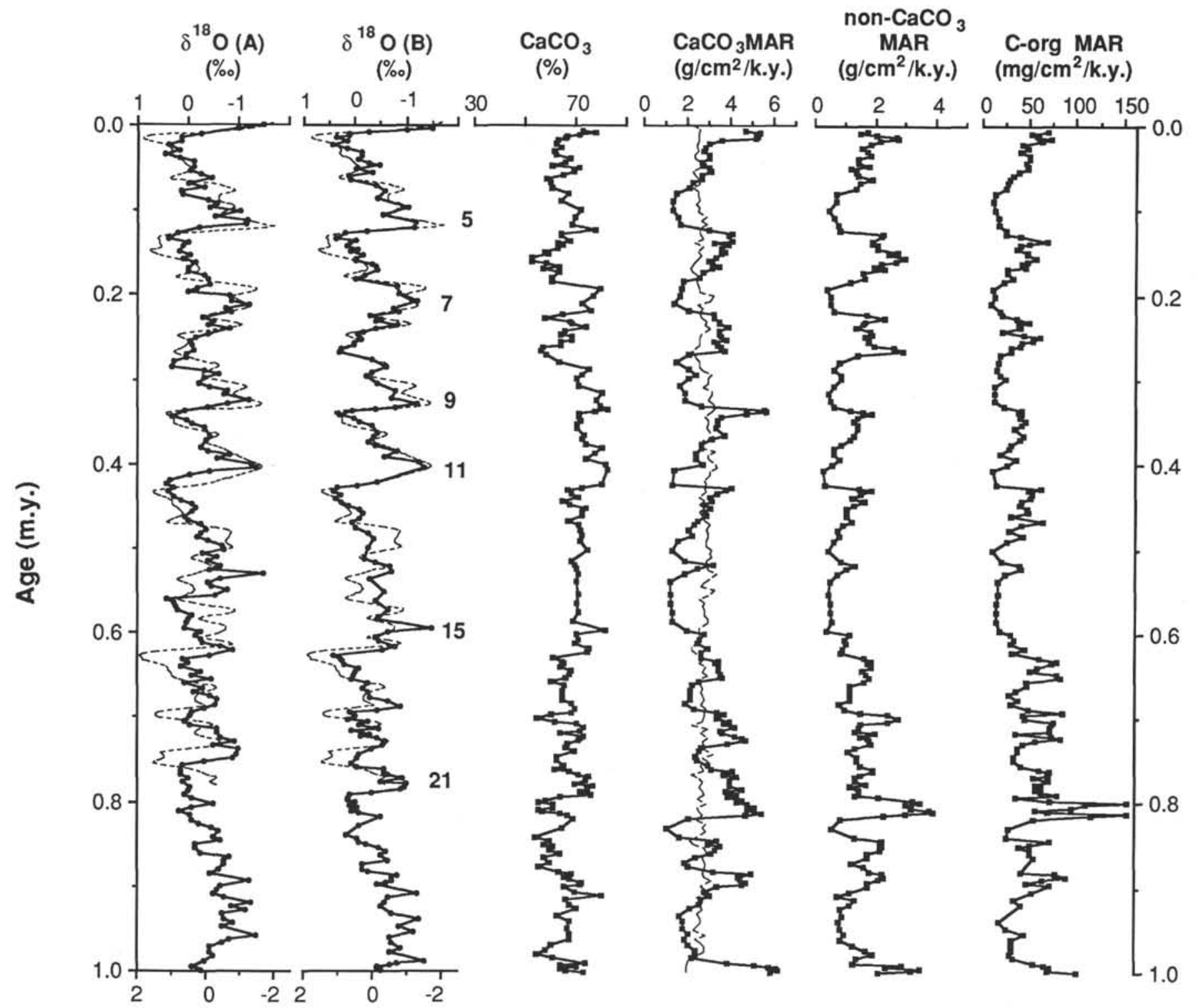

Figure 7. Oxygen isotope composition of G. sacculifer, carbonate percent, carbonate MAR, noncarbonate MAR, and organic carbon MAR time series from Hole 722B. The two oxygen isotope profiles reflect differences between chronologies based on (A) magnetostratigraphy and (B) isotope stratigraphy. For comparison, the thin dashed line on each time series is the SPECMAP stacked isotope record of (Imbrie et al., 1984). Interglacial stages 5-21 are noted. The $\mathrm{CaCO}_{3} \%$ and the mass accumulation rate profiles (solid line) use the isotope-based chronology and the thin dashed line for the $\mathrm{CaCO}_{3}$ MAR time series relies on the magnetic reversal age model.

frequency variations in MAR calculated with sedimentation rates derived from the isotope age model. This emphasizes the fact that only average or long-terms trends in the MAR's can be determined with a low resolution age model at Site 722. The Pliocene section that begins near $3.4 \mathrm{Ma}$ is characterized by low $\mathrm{CaCO}_{3}$ fluxes of about $1 \mathrm{~g} / \mathrm{cm}^{2} / \mathrm{k}$.y. This rate increases by a factor of three from the late Pliocene to Present.

Organic carbon accumulation exhibits more variable changes over the last 3.4 m.y. (Fig. 9). Between 2.8 and 3.4 Ma, the average rates were low and close to present values of $20-30 \mathrm{mg} / \mathrm{cm}^{2} /$ k.y. The accumulation rates then increase after $2.8 \mathrm{Ma}$ to a maximum of $125 \mathrm{mg} / \mathrm{cm}^{2} / \mathrm{k}$.y. near $2.4 \mathrm{Ma}$. This increase in organic carbon accumulation precedes the rise in calcium carbonate accumulation near $2.4 \mathrm{Ma}$. The average organic carbon MAR decreases from the late Pliocene to Pleistocene with present values near $30 \mathrm{mg} / \mathrm{cm}^{2} / \mathrm{k}$.y. for the top of the Owen Ridge. Since the high carbon accumulation rates near $2.4 \mathrm{Ma}$ are associated with an interval of lower mean sedimentation rate compared to the Present, the high rates in the late Pliocene cannot be attributed to sedimentation rate enhanced preservation. This implies that oceanographic conditions were more favorable for organic carbon production in the late Pliocene compared to the present, due either to the local influence of monsoonal upwelling or regional oceanographic changes which provide more nutrients to the surface waters. These changes are also noted in the nearby sites on Oman Margin (Prell, Niitsuma, et al., 1989). The margin sites are characterized by laminated sediments with increases in opal and organic carbon over the interval from 1.5 to $3.4 \mathrm{Ma}$. The presence of laminae at the margin sites implies that the oxygen minimum zone was intensified during the late Pliocene.

Coarse fraction $(>150 \mu \mathrm{m})$ weight percent exhibits a trend similar to the carbonate mass accumulation rate and inverse to the organic carbon profile. The coarse fraction is mostly com- 


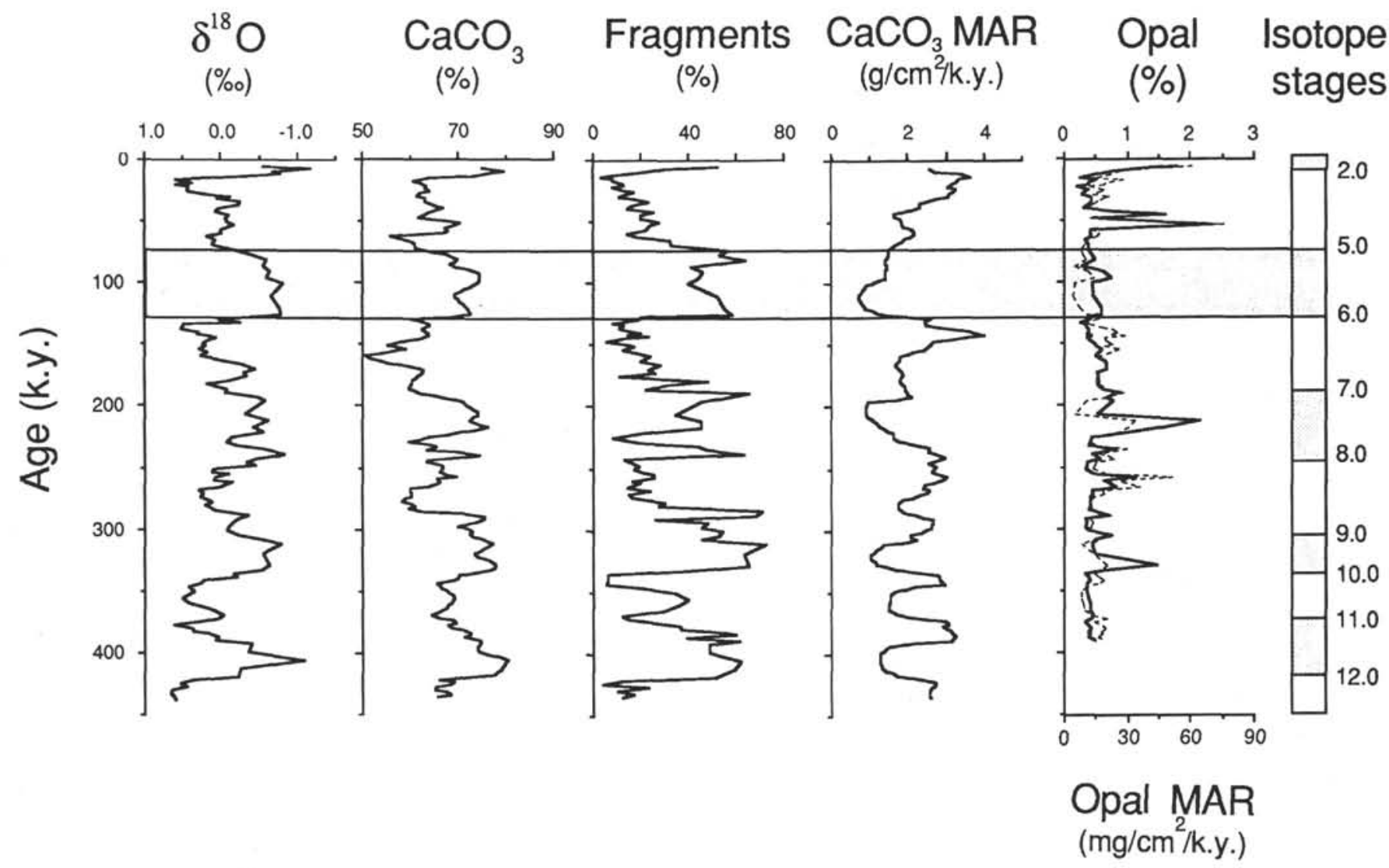

Figure 8. Time series of $\delta^{18} \mathrm{O}, \mathrm{CaCO}_{3} \%$, foraminifer fragments, calcium carbonate mass accumulation rate, opal percent, and opal accumulation for the upper $12.96 \mathrm{~m}$ of piston core RC27-61. Oxygen isotope stages are shown for reference and interglacial stage 5 is highlighted.

posed of calcite, and the low values prior to $1.5 \mathrm{Ma}$ suggest that the older samples are more dissolved than younger material. This pattern is consistent with more organic carbon production in the late Pliocene compared to the present. Upon decomposition, the organic carbon will produce $\mathrm{CO}_{2}$ which enhances carbonate dissolution. A more detailed analysis of the amplitude and timing of these events awaits a high resolution age model for the interval older than $1 \mathrm{Ma}$.

\section{DISCUSSION}

The 3.4 m.y. time series of bulk changes in sediment composition on the Owen Ridge (Figs. 5 and 9) reveal a high frequency scale of variation close to 23 k.y. (i.e., the period associated with changes in the earth's precession cycle). We focus our discussion on the significance of the dominant periods of change and the relative timing among the sedimentary components considered in this study. Standard time series analysis (Jenkins and Watts, 1968) is used to quantify these relationships. As noted previously, noncarbonate $\left(100-\mathrm{CaCO}_{3} \%\right)$ and magnetic susceptibility reflect the terrigenous percent changes and match temporal variations in terrigenous accumulation during the past 1 m.y. (see Clemens and Prell, this volume). Therefore, $\mathrm{CaCO}_{3} \%$ can be used to determine the dominant period of variation of the lithogenic component. Because of the large variation in sedimentation rate between glacial and interglacial stages, spectra for the interval from 0 to $1 \mathrm{Ma}$ differ depending on whether we use a coarse or high resolution age model (Fig. 10). Using the oxygen isotope-based chronology, $\mathrm{CaCO}_{3} \%$ variance is concentrated in the 100,41 , and 23 k.y. bands that are common in deep-sea paleoclimatic records and associated with astronomical-forced changes in climate (Fig. 10A). The accumulation record also has concentrations of variance in the orbital bands, but the low frequency bands dominate. This may be due, in part, to our inability to resolve high frequency variations in sedimentation rate in the Hole 722B record (Clemens and Prell, this volume). Similar periods are present in the records of calcium carbonate concentration (Fig. 10B) and accumulation (Fig. 10D) with the low resolution magnetic reversal based chronology (Fig. 10B), but substantial differences exist in the distribution of variance. To avoid these errors resulting from inaccuracies in the low resolution age model, we focus our discussion on the record from the last $1 \mathrm{~m}$.y. where a high resolution chronostratigraphy is available.

Within the last $1 \mathrm{~m} . \mathrm{y}$., most of the time series considered in this study contain one or all three of the frequency bands associated with astronomical-forced changes in climate. We use cross spectral analysis to better understand the relationships among the major sediment components and to compare their temporal changes to global and regional climatic variations. All time series are compared to an orbital curve referred to as ETP (Imbrie et al., 1984), and the results of the phase spectrum in the orbital bands are summarized in Table 4. The ETP curve is derived by normalizing and then summing time series of eccentricity (100 k.y.), obliquity (41 k.y.), and (negative) precession ( $23 \mathrm{k}$.y.). The resulting curve contains the relative amplitude and phase of all frequencies associated with the orbital variations.

Previous time series analysis of Owen Ridge sediments by Prell (1984a) noted that the record of Globigerina bulloides, which is used as an upwelling index in the Arabian Sea, is coherent with 23 k.y. precessional changes. This result and subsequent work by Prell and Kutzbach (1987) confirm that variations in solar radiation are the primary forcing for the regional monsoon circulation during the late Quaternary. However, a significant lag of 5-9 k.y. exists between the proposed forcing 


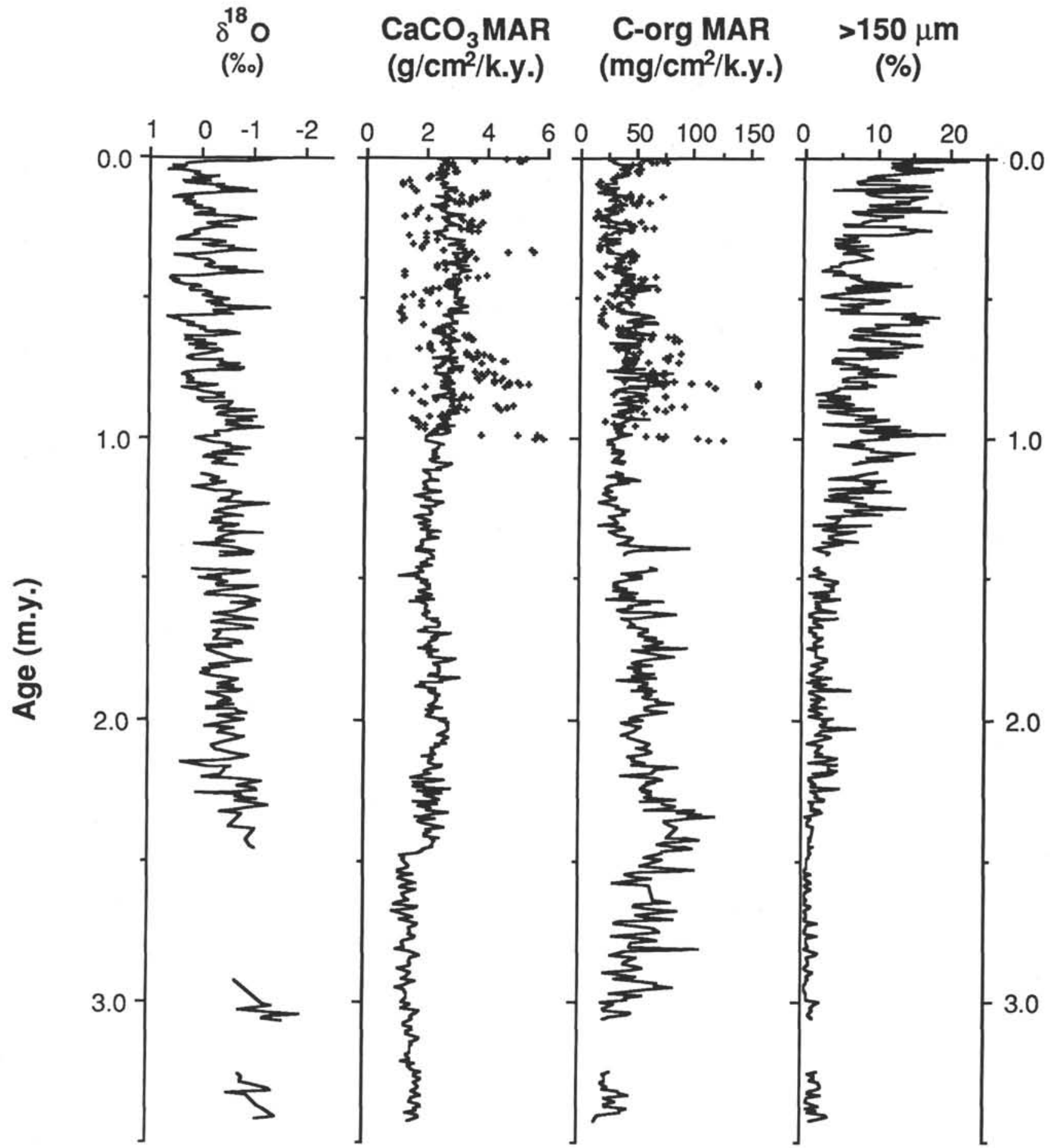

Figure 9. Time series of planktonic $\delta^{18} \mathrm{O}(\%)$, calcium carbonate and organic carbon mass accumulation rates, and coarse fraction ( $\left.>150 \mu \mathrm{m}\right)$ from Hole 722B composite data. The ages for the isotope data are derived from the low resolution magnetic reversal chronology. Data represented by the solid lines in the MAR profiles use chronologies based on magnetic stratigraphy and the pluses represent values calculated using the oxygen isotope based age model.

(maximum precessional radiation referenced to June 21) and indices of monsoon strength (Prell, 1984a; Prell and Kutzbach, 1987; Clemens and Prell, this volume). This lag suggests that internal feedbacks within the climate system are necessary to explain the observed temporal variations preserved in the deep-sea record. Conceptual models which consider these feedbacks are discussed by Prell (1984a) and Clemens and Prell (1990).
The time series of the oxygen isotopic composition of Globigerinoides sacculifer is coherent and in phase with the SPECMAP stack within each of the orbital bands over the intervals common to both records. This indicates that our age model is reliable and phase differences between other sediment indices and the ETP time series within the orbital bands cannot be attributed to inaccuracies in the age model. The reported phases 

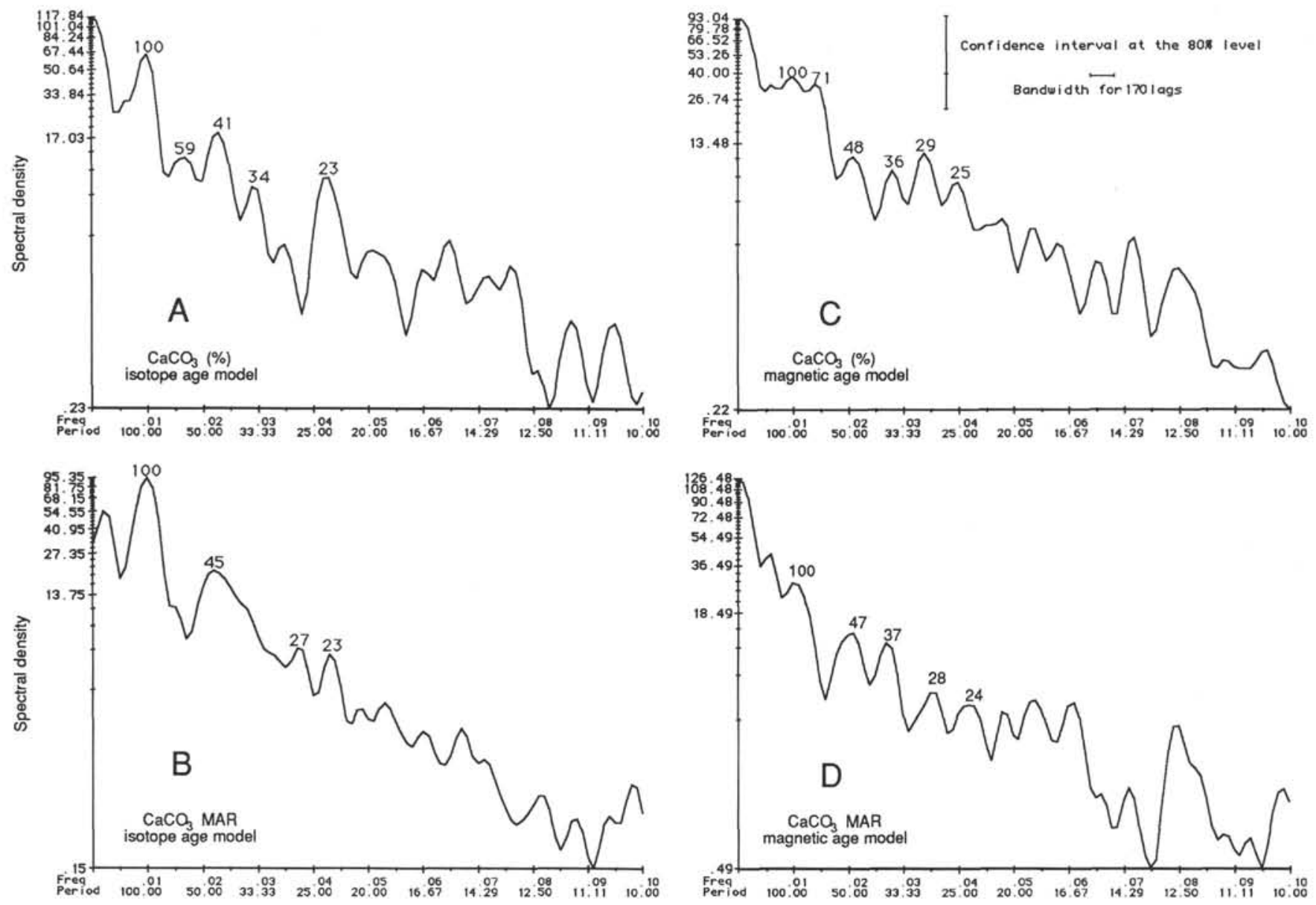

Figure 10. Variance spectra of Hole 722 $\mathrm{B} \mathrm{CaCO} \mathrm{Ca}_{3} \%$ and MAR data from 0 to 1000 k.y. using (A and $\mathbf{C}$ ) the oxygen isotope- and (B and $\mathbf{D}$ ) the magnetic reversal-based chronologies. Spectra are plotted on a linear frequency scale and a log variance density scale. The bandwidth and the confidence interval for the $80 \%$ level are shown.

Table 4. Summary of cross spectral analysis."

\begin{tabular}{|c|c|c|c|c|c|c|}
\hline \multirow[b]{2}{*}{ Time series $^{\mathrm{a}}$} & \multicolumn{2}{|c|}{100 k.y. } & \multicolumn{2}{|c|}{41 k.y. } & \multicolumn{2}{|c|}{23 k.y. } \\
\hline & Phase & Coherency & Phase & Coherency & Phase & Coherency \\
\hline$-\delta^{18} \mathrm{O}(\% 0)(\min i c e)$ & $-7 \pm 15^{\circ}$ & 0.86 & $-79 \pm 8^{\circ}$ & 0.93 & $-84 \pm 11^{\circ}$ & 0.92 \\
\hline $\mathrm{CaCO}_{3}(\%)$ & $+13 \pm 15^{\circ}$ & 0.64 & $-48 \pm 21^{\circ}$ & 0.76 & $-76 \pm 9^{\circ}$ & 0.95 \\
\hline Mag. susceptibility & $-180 \pm 28^{\circ}$ & 0.66 & $+144 \pm 26^{\circ}$ & 0.69 & $+72 \pm 18^{\circ}$ & 0.81 \\
\hline $\mathrm{CaCO}_{3}$ MAR & $+116 \pm 22^{\circ}$ & 0.74 & - & - & - & - \\
\hline non- $\mathrm{CaCO}_{3}$ MAR & $+135 \pm 25^{\circ}$ & 0.70 & $+144 \pm 27^{\circ}$ & 0.66 & - & - \\
\hline C-org (\%) & $+173 \pm 26^{\circ}$ & 0.69 & - & - & $+138 \pm 27^{\circ}$ & 0.66 \\
\hline C-org MÁR & $+133 \pm 22^{\circ}$ & 0.74 & - & - & $+94 \pm 23^{\circ}$ & 0.74 \\
\hline Opal (\%) & - & - & $-12 \pm 17^{\circ}$ & 0.85 & $-132 \pm 9^{\circ}$ & 0.94 \\
\hline Opal MAR & $+156 \pm 30^{\circ}$ & 0.65 & $+31 \pm 15^{\circ}$ & 0.87 & $-128 \pm 10^{\circ}$ & 0.94 \\
\hline
\end{tabular}

\footnotetext{
a Summary of phase spectra between Hole 722B time series and ETP for Milankovitch frequency bands. Positive values indicate that the record leads ETP, and negative values indicate a lag. For all cross spectra but RC27-61 opal\% and MAR: record length = 6-1000 k.y.; sample interval = 2 k.y.; \# of lags = 170; bandwidth $=0.004$; and the test statistic for nonzero coherency at the $80 \%$ confidence level $=0.65$. For opal $\%$ and MAR: record length $=6-388 \mathrm{k} . \mathrm{y} . ;$ sample interval $=2 \mathrm{k} . \mathrm{y} . ;$ of lags $=75$; bandwidth $=0.009$; and the test statistic $=0.69$.
}

of the oxygen isotope record relative to ETP are consistent with the time constant for changes in ice volume (Imbrie et al., 1984). Since Pleistocene ice volume controls global changes in sea level, the phases also reflect the relative timing of maximum sea level.

In general, $\mathrm{CaCO}_{3} \%$ is in phase and highly correlated with ice minimum/sea level maximum, and $180^{\circ}$ out of phase with the lithogenic component as represented by the magnetic sus- ceptibility and noncarbonate accumulation records (Table 4). Although these 0-1 Ma time series of the lithogenic component exhibit a strong concentration of variance at $23 \mathrm{k} . \mathrm{y}$., which accounts for much of the documented compositional changes in the preliminary shipboard results (Prell, Niitsuma, et al., 1989), the timing is not consistent with indices of monsoon wind strength. In fact, lithogenic concentration and accumulation are at a maximum during glacial intervals (minimum ice phase- 
$180^{\circ}$; Table 4) when the monsoon circulation is thought to be weakest (Prell and Kutzbach, 1987). The process(es) responsible for the positive association of maximum terrigenous concentration and accumulation with minimum sea level/maximum glacial conditions is discussed in detail by Clemens and Prell (1990).

Calcium carbonate accumulation is only coherent with ETP within the 100 k.y. band and is greatest during the maximum rate of sea-level rise. This site is above the regional lysocline, which lies at approximately $3400 \mathrm{~m}$ (Cullen and Prell, 1984), so the accumulation may reflect carbonate productivity. However, the phase relationship is not consistent with other indices of monsoon strength (Prell and Kutzbach, 1987; Clemens and Prell, 1990). This implies that if the changes are due to carbonate productivity in this area, they are not linked in a simple manner to monsoon-induced upwelling. The phase of maximum carbonate accumulation does correspond to the least amount of foraminifer fragmentation in the 434,000 yr record from RC2761. In addition, the low frequency changes in carbonate accumulation at Site $\mathbf{7 2 2}$ are in phase with the record of lysocline variations from the equatorial Indian Ocean (Peterson and Prell, 1985) where maximum dissolution corresponds to the maximum rate of sea-level rise. This evidence suggests that during the last $1 \mathrm{~m} . \mathrm{y}$., the low frequency variations in carbonate accumulation are driven by dissolution. The shoaling of the regional lysocline in the northern Arabian Sea could result from the high flux of organic carbon associated with this zone of high productivity. From the difference in the average glacial and interglacial rates of carbonate accumulation ( 4 and $1 \mathrm{~g} / \mathrm{cm}^{2} / \mathrm{k}$.y., respectively) we estimate that, as the lysocline shoals, an additional $3 \mathrm{~g} / \mathrm{cm}^{2} /$ k.y. is dissolved in the interglacial periods compared to glacial intervals. If carbonate productivity follows variations in the monsoon (i.e., increased flux during interglacials), then the primary flux of carbonate would be greater and the amount dissolved between glacial and interglacial intervals would be even larger. This process would provide an effective transfer of carbon from the surface to intermediate waters during interglacial intervals.

Organic carbon accumulation in the Owen Ridge sediments is highly correlated with the terrigenous component variations which drives sedimentation rate changes in this region (Fig. 9). If the organic carbon component reflects variations in primary productivity, then our results imply that local carbon production does not correspond to temporal changes in the strength of the summer monsoon, as inferred from other sediment indices (Prell and Kutzbach, 1987; Clemens and Prell, 1990). Alternatively, the record of organic carbon accumulation is dominated by sedimentation rate enhanced preservation. Our preliminary attempts to remove the effect of sedimentation rate variations using the empirical relationships established by Müller and Suess (1979) and Sarnthein et al. (1988) do not change the timing of the organic carbon cycles; the greater flux of organic carbon is still associated with glacial intervals and not other indices of monsoon strength. Further work is necessary to resolve these discrepancies.

The temporal changes in opal concentration and accumulation during the past 388,000 yr on the crest of the Owen Ridge are similar to and in phase with other indices of monsoon strength such as Globigerina bulloides and terrigenous grain size (Clemens and Prell, 1990). All three monsoon indices exhibit a 5-9 k.y. lag relative to changes in northern hemisphere summer insolation. The sharp increases in opal accumulation reflect intervals of enhanced preservation and are linearly correlated to increased northern hemisphere radiation. However, the amplitude of the opal changes is not simply linked with insolation changes. Our preliminary analysis suggests that the siliceous component of the sediments may be a reliable monitor of variations in the intensity of the monsoon and can be used to evaluate long-term changes in regional imprint of the southwest monsoon in the Arabian Sea.

\section{CONCLUSIONS}

This study of the major biogenic components of PliocenePleistocene sediments from the Owen Ridge reveals that percent noncarbonate (mostly lithogenic), organic carbon, opal, and volume magnetic susceptibility vary with periods similar to those expected for a system driven by monsoon upwelling and forced by changes in northern hemisphere insolation. However, only opal exhibits a relative timing consistent with a monsoonal-forced system. Variations in percent calcium carbonate, the major sediment component, result from terrigenous dilution and do not reflect changes in the carbonate system. The factorof-two increase in the mean rate of calcium carbonate accumulation during the past 3.4 m.y., originally thought to reflect the long-term increase in the strength of the monsoon system, most likely results from greater dissolution of the carbonate component in Pliocene sediments compared to the Present. Within the late Pleistocene, large amplitude $\left(1-6 \mathrm{~g} / \mathrm{cm}^{2} / \mathrm{k}\right.$.y.) variations in calcium carbonate accumulation can be resolved. These cycles are attributed to carbonate dissolution. Since this site is well above the regional lysocline, the cycles are presumed to reflect a shoaling of the local lysocline in an area influenced by high primary productivity in the surface waters. Therefore, these dissolution cycles may provide an indirect monitor of organic carbon flux to the sediments.

\section{ACKNOWLEDGMENTS}

This research was supported by grants from the National Science Foundation (OCE-8511571) and JOI/USSAC(TAMRF20172). Dr. P. Froelich and R. Mortlock (LDGO) kindly provided us with laboratory supplies and machine time for the RC27-61 opal measurements. We gratefully acknowledge S. Balakrishnan (C-org), J. Harrigan ( $\mathrm{CaCO}_{3}$; coarse fraction), T. Saha (coarse fraction); E. Grossman $\left(\mathrm{CaCO}_{3}\right)$; D. Verardo (LDGO-opal); and A. deCharon (opal) for their technical help.

\section{REFERENCES}

Clemens, S. C., and Prell, W. L., 1990. Late Pleistocene variability of Arabian Sea summer-monsoon winds and dust source-area aridity: eolian records from the lithogenic component of deep-sea sediments. Paleoceanography, 5:109-145.

Cullen, J., and Prell, W. L., 1984. Planktonic foraminifera of the northern Indian Ocean: distribution and preservation in surface sediments. Mar. Micropaleontol., 9:1-52.

Fischer, K., Dymond, J., Lyle, M., Soutar, A., and Rau, S., 1986. The benthic cycle of copper: evidence from sediment trap experiments in the eastern tropical North Pacific Ocean. Geochim. Cosmochim. Acta, 50:1535-1543.

Imbrie, J., Hays, J. D., Martinson, D. G., McIntyre, A., Mix, A. C., Morley, J. J., Pisias, N. G., Prell, W. L., and Shackleton, N. J., 1984. The orbital theory of Pleistocene climate: support from a revised chronology of the marine delta $\delta^{18} \mathrm{O}$ record. In Berger, A., Imbrie, J., Hays, J., Kukla, G., and Saltzman, B. (Eds.), Milankovitch and Climate (Pt. 1): Dordrecht (D. Reidel), 269-305.

Jenkins, G. M., and Watts, D. G., 1968. Spectral Analysis and its Applications: Oakland (Holden Day).

Jones, G. A., and Kaiteris, P., 1983. A vacuum-gasometric technique for rapid and precise analysis of calcium carbonate in sediments and soils. J. Sediment. Petrol., 53:655-660.

Kutzbach, J. E., and Guetter, P. J., 1986. The influence of changing orbital parameters and surface boundary conditions on climate simulations for the past 18,000 years. J. Atmos. Sci., 43:1726-1759.

Mortlock, R. A., and Froelich, P. N., 1989. A simple method for the rapid determination of biogenic opal in pelagic marine sediments. Deep-Sea Res. Part A, 36:1415-1426.

Müller, P. J., and Suess, E., 1979. Productivity, sedimentation rate, and sedimentary organic matter in the oceans. I. Organic carbon preservation. Deep-Sea Res. Part A, 26:1347-1362. 
Peterson, L. C., and Prell, W. L., 1985. Carbonate preservation and rates of climatic change: an $800 \mathrm{kyr}$ record from the Indian Ocean. In Sundquist, E. T., and Broecker, W. S. (Eds.), The Carbon Cycle and Atmospheric $\mathrm{CO}_{2}:$ Natural Variations Archean to Present: Am. Geophys. Union Monogr., 32:251-270.

Prell, W. L., 1984a. Monsoonal climate of the Arabian Sea during the late Quaternary: a response to changing solar radiation. In Berger, A. L., Imbrie, J., Hays, J., Kukla, G., and Saltzman, B. (Eds.). Milankovitch and Climate (Pt. 1): Dordrecht (D. Reidel), 349-366.

1984b. Variation of monsoonal upwelling: a response to changing solar radiation. In Hansen, J. E., and Takahashi, T. (Eds.), Climatic Processes and Climate Sensitivity. Am. Geophys. Union, Maurice Ewing Ser., 29:48-57.

Prell, W. L., and Kutzbach, J. E., 1987. Monsoon variability over the past 150,000 years. J. Geophys. Res., 92:8411-8425.

Prell, W. L., Niitsuma, N., et al., 1989. Proc. ODP, Init. Repts., 117: College Station, TX (Ocean Drilling Program).

Prell, W. L., and Van Campo, E., 1986. Coherent response of Arabian Sea upwelling and pollen transport to late Quaternary monsoonal winds. Nature, 323:526-528.

Raymo, M. E., Ruddiman, W. F., Backman, J., Clement, B. M., and Martinson, D. G., 1989. Late Pliocene variation in Northern Hemisphere ice sheets and North Atlantic Deep Water circulation. Paleoceanography, 4:413-446.
Ruddiman, W. F., Raymo, M. E., Martinson, D. G., Clement, B. M., and Backman, J., 1989. Pleistocene evolution: Northern Hemisphere ice sheets and North Atlantic Ocean. Paleoceanography, 4:353-412.

Sarnthein, M., and Winn, K., Duplessy, J.-C., Fontugne, M. R., 1988. Global variations of surface ocean productivity in low and mid latitudes: influence on $\mathrm{CO}_{2}$ reservoirs of the deep ocean and atmosphere during the last 21,000 years. Paleoceanography, 3:361-399.

Shipboard Scientific Party, 1989. Site 722. In Prell, W. L., Niitsuma, N., et al., Proc. ODP, Init. Repts., 117: College Station, TX (Ocean Drilling Program), 255-318.

Sirocko, F., and Sarnthein, M., 1989. Wind-borne deposits in the northwest Indian Ocean: record of Holocene sediments versus modern satellite data. In Leinen, M., and Sarnthein, M. (Eds.), Paleoclimatology and Paleometeorology: Modern and Past Patterns of Global Atmospheric Transport. NATO ASI Ser., 282:401-433.

Verardo, D., Froelich, P. N., McIntrye, A., 1990. Determination of organic carbon and nitrogen in marine sediments using the Carlo Erba NA-1500 Analyzer, Deep-Sea Res. Part A, 37:157-165.

Date of initial receipt: 28 September 1989

Date of acceptance: 25 July 1990

Ms 117B-141 
APPENDIX

Hole 722B Composite

\begin{tabular}{|c|c|c|c|c|c|c|c|c|c|c|c|c|c|c|}
\hline $\begin{array}{l}\text { Core, } \\
\text { section }\end{array}$ & $\begin{array}{l}\text { Section } \\
\text { depth } \\
(\mathrm{cm})\end{array}$ & $\begin{array}{l}\text { ODP } \\
\text { depth } \\
\text { (m) }\end{array}$ & $\begin{array}{l}\text { Composite } \\
\text { depth } \\
\text { (m) }\end{array}$ & $\begin{array}{l}\text { Ship }^{b} \\
\text { age } \\
\text { (m.y.) }\end{array}$ & $\begin{array}{c}\text { Ship } \\
\text { sed. rate } \\
(\mathrm{cm} / \mathrm{k} . \mathrm{y} .)\end{array}$ & $\begin{array}{l}\text { Isotope }{ }^{c} \\
\text { age } \\
\text { (m.y.) }\end{array}$ & $\begin{array}{l}\text { Isotope } \\
\text { sed. rate } \\
(\mathrm{cm} / \mathrm{k} . \mathrm{y} .)\end{array}$ & $\begin{array}{l}\text { Composited } \\
\text { susceptibility } \\
\left(10^{-6} \mathrm{cgs}\right)\end{array}$ & $\begin{array}{c}\text { Composite } \\
\text { density } \\
\left(\mathrm{g} / \mathrm{cm}^{3}\right)\end{array}$ & $\underset{(\%)}{\mathrm{CaCO}_{3}}$ & $\begin{array}{c}\text { Composite }^{f} \\
\mathrm{CaCO}_{3} \\
(\%)\end{array}$ & $\begin{array}{l}>150 \\
\mu \mathrm{m} \\
(\%)\end{array}$ & $\begin{array}{c}\text { C-org } \\
(\%)\end{array}$ & $\begin{array}{l}\delta^{18} \mathrm{O} \\
(\%(\%)\end{array}$ \\
\hline $1 \mathrm{H}-1$ & 1 & 0.01 & 0.01 & 0.0002 & 4.12 & 0.0060 & 8.47 & 87.00 & 0.756 & 73.17 & 73.17 & 12.1 & 1.067 & -1.470 \\
\hline $1 \mathrm{H}-1$ & 21 & 0.21 & 0.21 & 0.0051 & 4.12 & 0.0084 & 8.47 & 83.64 & 0.812 & 78.05 & 78.05 & 22.4 & 0.748 & -0.970 \\
\hline $1 \mathrm{H}-1$ & 41 & 0.41 & 0.41 & 0.0100 & 4.12 & 0.0107 & 8.47 & $\mathrm{~g}_{10.96}$ & 0.847 & 71.69 & 71.69 & 21.8 & 0.783 & -0.225 \\
\hline $1 \mathrm{H}-1$ & 61 & 0.61 & 0.61 & 0.0148 & 4.12 & 0.0131 & 8.47 & $\mathrm{~g}_{21.52}$ & 0.928 & 66.30 & 66.30 & 11.9 & 0.745 & 0.170 \\
\hline $1 \mathrm{H}-1$ & 81 & 0.81 & 0.81 & 0.0197 & 4.12 & 0.0154 & 8.47 & $\mathrm{~B}_{13.98}$ & 0.931 & 65.46 & 65.46 & 14.7 & 0.912 & 0.170 \\
\hline $1 \mathrm{H}-1$ & 101 & 1.01 & 1.01 & 0.0245 & 4.12 & 0.0178 & 6.19 & $\mathrm{~g}_{13.98}$ & 0.927 & 63.15 & 63.15 & 12.9 & 1.091 & 0.430 \\
\hline $1 \mathrm{H}-1$ & 121 & 1.21 & 1.21 & 0.0294 & 4.12 & 0.0219 & 4.87 & $\mathrm{~B}_{15.84}$ & 0.981 & 61.95 & 61.95 & 12.0 & 0.882 & 0.200 \\
\hline $1 \mathrm{H}-1$ & 141 & 1.41 & 1.41 & 0.0343 & 4.12 & 0.0260 & 4.87 & $\mathrm{~g}_{10.60}$ & 0.895 & 64.15 & 64.15 & 18.9 & 1.110 & 0.490 \\
\hline $1 \mathrm{H}-2$ & 11 & 1.61 & 1.61 & 0.0391 & 4.12 & 0.0301 & 4.87 & $\mathrm{~g}_{15.08}$ & 0.918 & 61.66 & 61.66 & 12.5 & 0.911 & 0.230 \\
\hline $1 \mathrm{H}-2$ & 31 & 1.81 & 1.81 & 0.0440 & 4.12 & 0.0342 & 4.87 & $\mathrm{~g}_{12.58}$ & 0.998 & 62.11 & 62.11 & 15.0 & 1.027 & -0.060 \\
\hline $1 \mathrm{H}-2$ & 51 & 2.01 & 2.01 & 0.0488 & 4.12 & 0.0383 & 4.87 & 89.42 & 0.908 & 68.06 & 68.06 & 17.5 & 1.120 & -0.080 \\
\hline $1 \mathrm{H}-2$ & 71 & 2.21 & 2.21 & 0.0537 & 4.12 & 0.0424 & 4.87 & $8_{6.52}$ & 0.845 & 65.51 & 65.51 & 13.8 & 1.111 & -0.010 \\
\hline $1 \mathrm{H}-2$ & 91 & 2.41 & 2.41 & 0.0585 & 4.12 & 0.0465 & 4.88 & $8_{6.02}$ & 0.919 & 60.84 & 60.84 & 10.2 & 1.054 & -0.220 \\
\hline $1 \mathrm{H}-2$ & 111 & 2.61 & 2.61 & 0.0634 & 4.12 & 0.0506 & 4.87 & $8_{3.38}$ & 0.862 & 71.13 & 71.13 & 9.9 & 1.122 & -0.440 \\
\hline $1 \mathrm{H}-2$ & 131 & 2.81 & 2.81 & 0.0683 & 4.12 & 0.0547 & 4.87 & 85.40 & 0.907 & 69.17 & 69.17 & 8.8 & 0.879 & 0.030 \\
\hline $1 \mathrm{H}-3$ & 1 & 3.01 & 3.01 & 0.0731 & 4.12 & 0.0588 & 4.87 & 89.44 & 0.842 & 64.87 & 64.87 & 12.8 & 0.790 & -0.300 \\
\hline $1 \mathrm{H}-3$ & 21 & 3.21 & 3.21 & 0.0780 & 4.12 & 0.0630 & 4.37 & $8_{19.76}$ & 1.050 & 58.55 & 58.55 & 8.8 & 0.625 & 0.190 \\
\hline $1 \mathrm{H}-3$ & 41 & 3.41 & 3.41 & 0.0828 & 4.12 & 0.0680 & 3.62 & $\mathrm{~g}_{15.12}$ & 1.021 & 59.80 & 59.80 & 7.3 & 0.746 & 0.150 \\
\hline $1 \mathrm{H}-3$ & 61 & 3.61 & 3.61 & 0.0877 & 4.12 & 0.0740 & 3.33 & 89.80 & 1.042 & 61.05 & 61.05 & 7.4 & 0.722 & -0.370 \\
\hline $1 \mathrm{H}-3$ & 81 & 3.81 & 3.81 & 0.0925 & 4.12 & 0.0800 & 2.58 & $8_{5.68}$ & 0.877 & 67.18 & 67.18 & 11.7 & 0.566 & -0.530 \\
\hline $1 \mathrm{H}-3$ & 101 & 4.01 & 4.01 & 0.0974 & 4.10 & 0.0895 & 2.11 & 85.96 & 0.970 & 64.07 & 64.07 & 17.1 & 0.531 & -0.410 \\
\hline $1 \mathrm{H}-3$ & 121 & 4.21 & 4.21 & 0.1023 & 4.12 & 0.0990 & 2.14 & $8_{3.38}$ & 0.850 & 72.30 & 72.30 & & 0.719 & -0.985 \\
\hline $1 \mathrm{H}-3$ & 141 & 4.41 & 4.41 & 0.1071 & 4.12 & 0.1082 & 2.17 & $8_{4.34}$ & 1.012 & 70.32 & 70.32 & 11.2 & 0.758 & -0.510 \\
\hline $1 \mathrm{H}-4$ & 11 & 4.61 & 4.61 & 0.1120 & 4.12 & 0.1174 & 2.60 & 87.16 & $\mathrm{~h}_{0.958}$ & 68.22 & 68.22 & 3.7 & 0.660 & -1.160 \\
\hline $1 \mathrm{H}-4$ & 31 & 4.81 & 4.81 & 0.1168 & 4.12 & 0.1236 & 4.30 & $8_{3.64}$ & $\mathrm{~h}_{0.897}$ & 78.13 & 78.13 & 17.3 & 0.655 & -1.110 \\
\hline $1 \mathrm{H}-4$ & 51 & 5.01 & 5.01 & 0.1217 & 4.12 & 0.1267 & 6.45 & $\mathrm{~g}_{13.00}$ & $\mathrm{~h}_{0.985}$ & 64.13 & 64.13 & 8.3 & 0.396 & -0.195 \\
\hline $1 \mathrm{H}-4$ & 71 & 5.21 & 5.21 & 0.1265 & 4.11 & 0.1298 & 6.39 & ${ }^{8} 10.22$ & ${ }^{\mathrm{h}} 0.965$ & 64.12 & 64.12 & 8.9 & 0.644 & 0.260 \\
\hline $2 \mathrm{H}-1$ & 4 & 5.54 & 5.54 & 0.1346 & 4.10 & 0.1350 & 6.10 & $\mathrm{~g}, \mathrm{~h}_{10.33}$ & $\mathrm{~h}_{0} 0.978$ & 65.52 & 68.14 & 10.8 & 1.139 & 0.430 \\
\hline $2 \mathrm{H}-1$ & 21 & 5.71 & 5.71 & 0.1387 & 4.16 & 0.1380 & 5.78 & ${ }^{8} 6.62$ & 0.887 & 62.90 & 62.90 & 16.6 & 0.951 & 0.050 \\
\hline $2 \mathrm{H}-1$ & 41 & 5.91 & 5.91 & 0.1435 & 4.12 & 0.1414 & 5.80 & 88.86 & 1.032 & 65.26 & 65.26 & 15.3 & 0.670 & 0.160 \\
\hline $2 \mathrm{H}-1$ & 61 & 6.11 & 6.11 & 0.1484 & 4.08 & 0.1449 & 5.71 & $8_{13.14}$ & 0.989 & 62.95 & 62.95 & 14.2 & 0.627 & 0.200 \\
\hline $2 \mathrm{H}-1$ & 81 & 6.31 & 6.31 & 0.1533 & 4.12 & 0.1484 & 5.71 & $\mathrm{~g}_{21.70}$ & 1.132 & 57.80 & 57.80 & 12.5 & 0.747 & -0.010 \\
\hline $2 \mathrm{H}-1$ & 101 & 6.51 & 6.51 & 0.1581 & 4.12 & 0.1519 & 5.80 & $\mathrm{~g}_{12.34}$ & 1.036 & 59.42 & 59.42 & 14.3 & 0.808 & 0.150 \\
\hline $2 \mathrm{H}-1$ & 121 & 6.71 & 6.71 & 0.1630 & 4.12 & 0.1553 & 5.80 & 8.42 & 1.081 & 52.57 & 52.57 & 8.9 & 0.900 & -0.120 \\
\hline $2 \mathrm{H}-1$ & 141 & 6.91 & 6.91 & 0.1678 & 4.12 & 0.1588 & 5.71 & 7.22 & 0.996 & 53.04 & 53.04 & 9.4 & 0.832 & 0.020 \\
\hline $2 \mathrm{H}-2$ & 11 & 7.11 & 7.11 & 0.1727 & 4.12 & 0.1623 & 5.71 & 5.26 & 0.940 & 58.91 & 58.91 & 11.8 & 0.797 & 0.020 \\
\hline $2 \mathrm{H}-2$ & 31 & 7.31 & 7.31 & 0.1775 & 4.12 & 0.1658 & 5.71 & 4.30 & 0.958 & 63.55 & 63.55 & 15.7 & 0.821 & -0.270 \\
\hline $2 \mathrm{H}-2$ & 51 & 7.51 & 7.51 & 0.1824 & 4.08 & 0.1693 & 5.26 & 5.44 & 1.043 & 57.47 & 57.47 & 8.6 & 0.486 & -0.360 \\
\hline $2 \mathrm{H}-2$ & 71 & 7.71 & 7.71 & 0.1873 & 4.12 & 0.1734 & 4.49 & 4.34 & 0.958 & 63.22 & 63.22 & 19.3 & 0.631 & -0.395 \\
\hline $2 \mathrm{H}-2$ & 91 & 7.91 & 7.91 & 0.1921 & 4.12 & 0.1782 & 4.17 & 4.52 & 1.025 & 60.82 & 60.82 & 6.4 & 0.753 & -0.140 \\
\hline $2 \mathrm{H}-2$ & 111 & 8.11 & 8.11 & 0.1970 & 4.12 & 0.1830 & 2.94 & 3.94 & 1.043 & 60.69 & 60.69 & 7.1 & 0.750 & 0.020 \\
\hline $2 \mathrm{H}-2$ & 131 & 8.31 & 8.31 & 0.2018 & 4.12 & 0.1918 & 2.26 & 1.06 & 0.978 & 80.02 & 80.02 & 10.4 & 0.522 & -0.785 \\
\hline $2 \mathrm{H}-3$ & 1 & 8.51 & 8.51 & 0.2067 & 4.12 & 0.2007 & 2.25 & 1.78 & 0.971 & 76.83 & 76.83 & 13.4 & 0.613 & -0.820 \\
\hline $2 \mathrm{H}-3$ & 21 & 8.71 & 8.71 & 0.2115 & 4.12 & 0.2096 & 2.26 & 2.46 & 0.842 & 73.01 & 73.01 & 10.6 & 0.543 & -1.170 \\
\hline $2 \mathrm{H}-3$ & 41 & 8.91 & 8.91 & 0.2164 & 4.08 & 0.2184 & 3.15 & 1.28 & 0.876 & 76.73 & 76.73 & 11.1 & 0.670 & -0.720 \\
\hline $2 \mathrm{H}-3$ & 61 & 9.11 & 9.11 & 0.2213 & 4.12 & 0.2223 & 5.13 & 2.18 & 0.963 & 65.27 & 65.27 & 9.3 & 0.416 & -0.830 \\
\hline $2 \mathrm{H}-3$ & 81 & 9.31 & 9.31 & 0.2261 & 4.12 & 0.2262 & 5.06 & 5.16 & 1.108 & 58.12 & 58.12 & 8.1 & 0.645 & -0.265 \\
\hline $2 \mathrm{H}-3$ & 101 & 9.51 & 9.51 & 0.2310 & 4.12 & 0.2302 & 5.06 & 3.38 & 1.025 & 68.15 & 68.15 & 7.6 & 0.942 & -0.480 \\
\hline $2 \mathrm{H}-3$ & 121 & 9.71 & 9.71 & 0.2358 & 4.12 & 0.2341 & 5.13 & 4.04 & 1.000 & 68.36 & 68.36 & 5.2 & 0.760 & -0.360 \\
\hline $2 \mathrm{H}-3$ & 141 & 9.91 & 9.91 & 0.2407 & 4.12 & 0.2380 & 5.26 & 2.32 & 1.009 & 74.14 & 74.14 & 5.7 & 0.755 & -0.790 \\
\hline $2 \mathrm{H}-4$ & 11 & 10.11 & 10.11 & 0.2455 & 4.12 & 0.2417 & 5.48 & 4.02 & 0.982 & 65.79 & 65.79 & 13.8 & 0.401 & -0.370 \\
\hline $2 \mathrm{H}-4$ & 31 & 10.31 & 10.31 & 0.2504 & 4.08 & 0.2453 & 5.48 & 3.86 & 0.982 & 64.62 & 64.62 & 13.2 & 0.816 & -0.110 \\
\hline $2 \mathrm{H}-4$ & 51 & 10.51 & 10.51 & 0.2553 & 4.12 & 0.2490 & 5.71 & 3.56 & 0.922 & 68.27 & 68.27 & 17.1 & 1.149 & -0.010 \\
\hline $2 \mathrm{H}-4$ & 71 & 10.71 & 10.71 & 0.2601 & 4.12 & 0.2523 & 5.97 & 2.74 & 0.931 & 68.28 & 68.28 & 15.2 & 0.966 & -0.030 \\
\hline $2 \mathrm{H}-4$ & 91 & 10.91 & 10.91 & 0.2650 & 4.12 & 0.2557 & 5.97 & 2.50 & 0.841 & 63.98 & 63.98 & 14.5 & 0.845 & -0.080 \\
\hline $2 \mathrm{H}-4$ & 111 & 11.1 & 11.11 & 0.2698 & 4.12 & 0.2590 & 6.06 & 2.88 & 0.889 & 64.05 & 64.05 & 11.5 & 0.743 & 0.070 \\
\hline $2 \mathrm{H}-4$ & 131 & 11.31 & 11.31 & 0.2747 & 4.12 & 0.2623 & 5.97 & 4.42 & 1.038 & 57.40 & 57.40 & 5.3 & 0.485 & 0.070 \\
\hline $2 \mathrm{H}-5$ & 1 & 11.51 & 11.51 & 0.2795 & 4.12 & 0.2657 & 5.97 & 4.98 & 1.118 & 56.28 & 56.28 & 7.1 & 0.470 & 0.310 \\
\hline $2 \mathrm{H}-5$ & 21 & 11.71 & 11.71 & 0.2844 & 4.08 & 0.2690 & 3.25 & 5.36 & 1.073 & 58.82 & 58.82 & 6.5 & 0.524 & 0.340 \\
\hline $2 \mathrm{H}-5$ & 41 & 11.91 & 11.91 & 0.2893 & 4.12 & 0.2780 & 2.22 & 3.88 & 1.038 & 63.69 & 63.69 & 4.2 & 0.783 & -0.290 \\
\hline $2 \mathrm{H}-5$ & 61 & 12.11 & 12.11 & 0.2941 & 4.12 & 0.2870 & 2.67 & 1.62 & 1.021 & 75.96 & 75.96 & 7.5 & 0.579 & -0.570 \\
\hline $2 \mathrm{H}-5$ & 81 & 12.31 & 12.31 & 0.2990 & 4.12 & 0.2930 & 3.33 & 2.14 & 1.005 & 72.84 & 72.84 & 4.9 & 0.582 & -0.290 \\
\hline $2 \mathrm{H}-5$ & 101 & 12.51 & 12.51 & 0.3038 & 4.12 & 0.2990 & 2.86 & 2.28 & 1.040 & 70.69 & 70.69 & 4.3 & 0.812 & -0.170 \\
\hline $2 \mathrm{H}-5$ & 121 & 12.71 & 12.71 & 0.3087 & 4.08 & 0.3070 & 2.50 & 1.70 & 0.934 & 71.26 & 71.26 & 4.2 & 0.552 & -0.385 \\
\hline $2 \mathrm{H}-5$ & 141 & 12.91 & 12.91 & 0.3136 & 4.12 & 0.3150 & 2.50 & 0.68 & 0.954 & 80.92 & 80.92 & 8.8 & 0.594 & -0.765 \\
\hline $2 \mathrm{H}-6$ & 11 & 13.11 & 13.11 & 0.3184 & 4.12 & 0.3230 & 2.50 & 2.32 & 0.980 & 78.53 & 78.53 & 4.5 & 0.579 & -0.680 \\
\hline $2 \mathrm{H}-6$ & 31 & 13.31 & 13.31 & 0.3233 & 4.12 & 0.3310 & 3.67 & 1.82 & 0.904 & 79.94 & 79.94 & 6.5 & 0.666 & -1.180 \\
\hline $2 \mathrm{H}-6$ & 51 & 13.51 & 13.51 & 0.3281 & 4.12 & 0.3339 & 7.02 & 1.86 & 0.967 & 82.53 & 82.53 & 9.4 & 0.610 & -0.750 \\
\hline $2 \mathrm{H}-6$ & 71 & 13.71 & 13.71 & 0.3330 & 4.12 & 0.3367 & 7.02 & 2.76 & 1.036 & 77.67 & 77.67 & 6.3 & 0.523 & -0.350 \\
\hline $2 \mathrm{H}-6$ & 91 & 13.91 & 13.91 & 0.3378 & 4.12 & 0.3396 & 6.25 & 3.22 & 1.066 & 71.58 & 71.58 & 5.5 & 0.624 & 0.110 \\
\hline $2 \mathrm{H}-6$ & 111 & 14.11 & 14.11 & 0.3427 & 4.08 & 0.3431 & 5.13 & 3.14 & 0.981 & 71.24 & 71.24 & 7.2 & 0.802 & $\mathrm{j}_{0.360}$ \\
\hline $2 \mathrm{H}-6$ & 131 & 14.31 & 14.31 & 0.3476 & 4.12 & 0.3474 & 4.71 & 3.18 & 1.011 & 72.08 & 72.08 & 8.5 & 0.975 & 0.060 \\
\hline $2 \mathrm{H}-7$ & 1 & 14.51 & 14.51 & 0.3524 & 4.12 & 0.3516 & 4.71 & 3.22 & ${ }^{h_{1}} .019$ & 70.78 & 70.78 & 9.0 & 0.863 & -0.050 \\
\hline $2 \mathrm{H}-7$ & 21 & 14.71 & 14.71 & 0.3573 & 4.11 & 0.3559 & 4.69 & $h_{3.32}$ & $\mathrm{~h}_{1.019}$ & 70.47 & 70.47 & 9.1 & 0.719 & -0.270 \\
\hline
\end{tabular}


Appendix (continued).

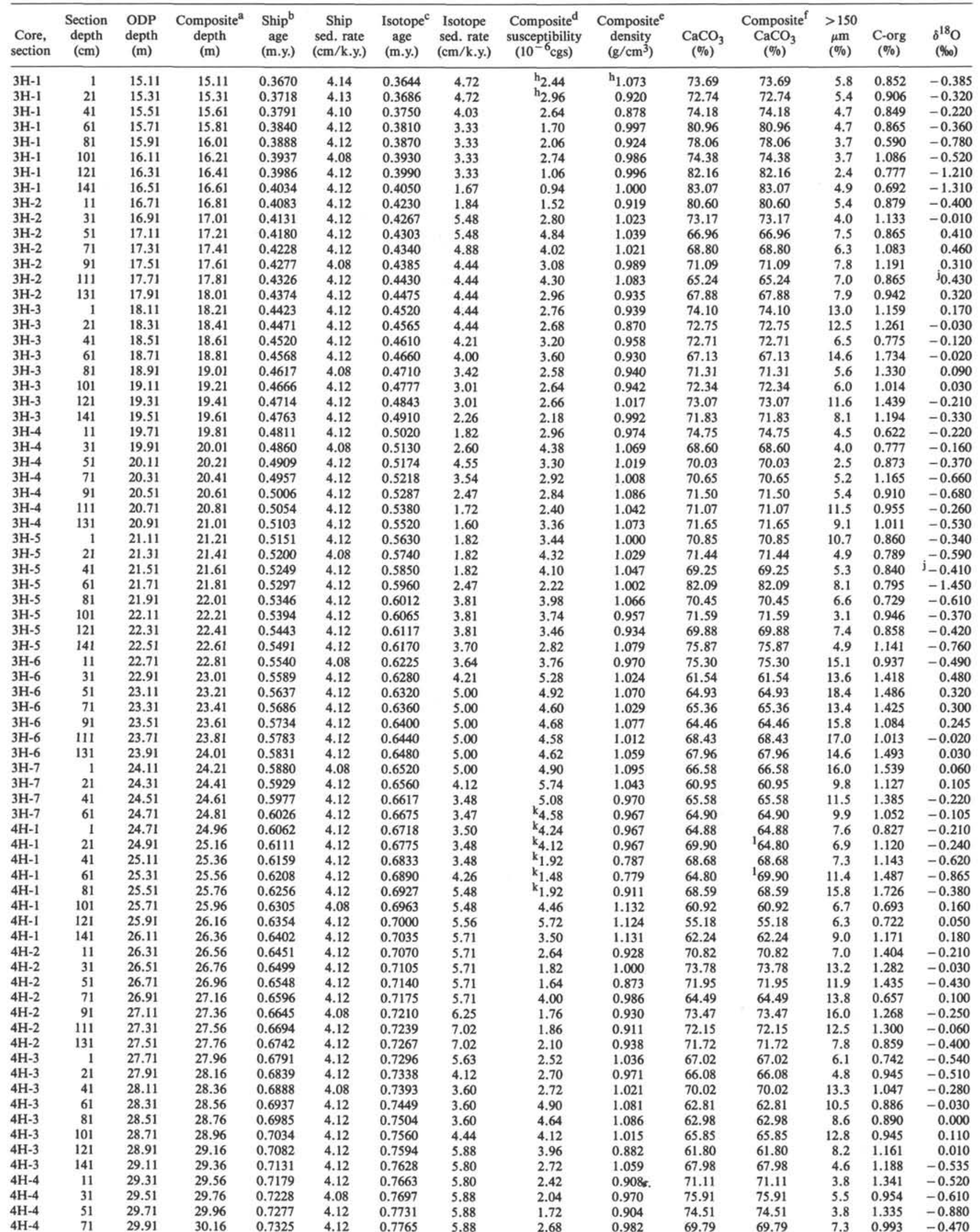


Appendix (continued).

\begin{tabular}{|c|c|c|c|c|c|c|c|c|c|c|c|c|c|c|}
\hline $\begin{array}{l}\text { Core, } \\
\text { section }\end{array}$ & $\begin{array}{l}\text { Section } \\
\text { depth } \\
\text { (cm) }\end{array}$ & $\begin{array}{l}\text { ODP } \\
\text { depth } \\
\text { (m) }\end{array}$ & $\begin{array}{l}\text { Composite }{ }^{\mathrm{a}} \\
\text { depth } \\
\text { (m) }\end{array}$ & $\begin{array}{l}\text { Ship }^{b} \\
\text { age } \\
\text { (m.y.) }\end{array}$ & $\begin{array}{l}\text { Ship } \\
\text { sed. rate } \\
(\mathrm{cm} / \mathrm{k} . \mathrm{y} .)\end{array}$ & $\begin{array}{l}\text { Isotope }^{c} \\
\text { age } \\
\text { (m.y.) }\end{array}$ & $\begin{array}{l}\text { Isotope } \\
\text { sed. rate } \\
(\mathrm{cm} / \mathrm{k} . \mathrm{y} .)\end{array}$ & $\begin{array}{l}\text { Composite }{ }^{\mathrm{d}} \\
\text { susceptibility }^{-6}\left(10^{-6} \mathrm{cgs}\right)\end{array}$ & $\begin{array}{l}\text { Composite } \\
\text { density } \\
\left(\mathrm{g} / \mathrm{cm}^{3}\right)\end{array}$ & $\begin{array}{c}\mathrm{CaCO}_{3} \\
(\%)\end{array}$ & $\begin{array}{c}\text { Composite }^{f} \\
\mathrm{CaCO}_{3} \\
(\%)\end{array}$ & $\begin{array}{l}>150 \\
\mu \mathrm{m} \\
(\%)\end{array}$ & $\begin{array}{l}\text { C-org } \\
(\%)\end{array}$ & $\begin{array}{l}\delta^{18} \mathrm{O} \\
\left(\%_{00}\right)\end{array}$ \\
\hline $4 \mathrm{H}-4$ & 91 & 30.11 & 30.36 & 0.7374 & 4.12 & 0.7799 & 5.88 & 1.64 & 0.885 & 77.40 & 77.40 & 6.9 & 1.208 & -0.970 \\
\hline $4 \mathrm{H}-4$ & 111 & 30.31 & 30.56 & 0.7422 & 4.12 & 0.7833 & 5.88 & 2.40 & 1.043 & 75.32 & 75.32 & 8.8 & 0.920 & -0.940 \\
\hline $4 \mathrm{H}-4$ & 131 & 30.51 & 30.76 & 0.7471 & 4.12 & 0.7867 & 5.80 & 2.06 & 0.916 & 71.80 & 71.80 & 5.1 & 1.176 & -0.870 \\
\hline $4 \mathrm{H}-5$ & 1 & 30.71 & 30.96 & 0.7519 & 4.12 & 0.7902 & 5.80 & 2.92 & 0.989 & 76.21 & 76.21 & 10.0 & 1.403 & -0.300 \\
\hline $4 \mathrm{H}-5$ & 21 & 30.91 & 31.16 & 0.7568 & 4.08 & 0.7936 & 5.88 & 5.36 & 1.023 & 64.47 & 64.47 & 8.3 & 0.614 & 0.130 \\
\hline $4 \mathrm{H}-5$ & 41 & 31.11 & 31.36 & 0.7617 & 4.12 & 0.7970 & 6.67 & 5.84 & 1.178 & 58.51 & 58.51 & 7.4 & 0.923 & 0.190 \\
\hline $4 \mathrm{H}-5$ & 61 & 31.31 & 31.56 & 0.7665 & 4.12 & 0.7996 & 7.84 & 5.50 & 0.997 & 55.44 & 55.44 & 9.3 & 1.984 & 0.180 \\
\hline $4 \mathrm{H}-5$ & 81 & 31.51 & 31.76 & 0.7714 & 4.12 & 0.8021 & 7.84 & 4.78 & 1.002 & 61.55 & 61.55 & 12.6 & 1.403 & 0.040 \\
\hline $4 \mathrm{H}-5$ & 101 & 31.71 & 31.96 & 0.7762 & 4.12 & 0.8047 & 7.69 & 5.16 & 1.086 & 61.75 & 61.75 & 6.3 & 1.139 & 0.130 \\
\hline $4 \mathrm{H}-5$ & 121 & 31.91 & 32.16 & 0.7811 & 4.12 & 0.8073 & 7.84 & 6.28 & 1.105 & 55.96 & 55.96 & 6.3 & 0.661 & 0.010 \\
\hline $4 \mathrm{H}-5$ & 141 & 32.11 & 32.36 & 0.7859 & 4.12 & 0.8098 & 7.84 & 6.42 & 1.164 & 56.87 & 56.87 & 5.4 & 0.775 & 0.030 \\
\hline $4 \mathrm{H}-6$ & 11 & 32.31 & 32.56 & 0.7908 & 4.08 & 0.8124 & 7.84 & 4.88 & 1.087 & 64.61 & 64.61 & 5.3 & 1.819 & 0.120 \\
\hline $4 \mathrm{H}-6$ & 31 & 32.51 & 32.76 & 0.7957 & 4.12 & 0.8149 & 7.84 & 2.42 & 0.896 & 67.37 & 67.37 & 8.6 & 1.664 & -0.020 \\
\hline $4 \mathrm{H}-6$ & 51 & 32.71 & 32.96 & 0.8005 & 4.12 & 0.8175 & 2.90 & 3.16 & 1.025 & 69.47 & 69.47 & 8.0 & 1.836 & -0.450 \\
\hline $4 \mathrm{H}-6$ & 71 & 32.91 & 33.16 & 0.8054 & 4.12 & 0.8287 & 1.79 & 5.04 & 0.927 & 64.90 & 64.90 & 9.7 & 1.692 & -0.030 \\
\hline $4 \mathrm{H}-6$ & 91 & 33.11 & 33.36 & 0.8102 & 4.12 & 0.8399 & 2.63 & 7.38 & 1.168 & 54.53 & 54.53 & 5.7 & 0.891 & 0.210 \\
\hline $4 \mathrm{H}-6$ & 111 & 33.31 & 33.56 & 0.8151 & 4.12 & 0.8439 & 5.00 & 6.04 & 1.132 & 59.79 & 59.79 & 8.8 & 1.264 & 0.000 \\
\hline $4 \mathrm{H}-6$ & 131 & 33.51 & 33.76 & 0.8199 & 4.12 & 0.8479 & 5.00 & 6.34 & 1.042 & 58.03 & 58.03 & 4.8 & 0.980 & -0.050 \\
\hline $4 \mathrm{H}-7$ & 1 & 33.71 & 33.96 & 0.8248 & 4.08 & 0.8519 & 5.00 & 5.80 & 1.166 & 61.34 & 61.34 & 4.7 & 0.689 & -0.180 \\
\hline $4 \mathrm{H}-7$ & 21 & 33.91 & 34.16 & 0.8297 & 4.12 & 0.8559 & 5.00 & 5.82 & $\mathrm{k}_{1.106}$ & 60.30 & 60.30 & 3.7 & 0.914 & -0.440 \\
\hline $4 \mathrm{H}-7$ & 41 & 34.11 & 34.36 & 0.8345 & 4.12 & 0.8600 & 4.55 & 5.20 & ${ }^{k_{1}} 1.093$ & 64.45 & 64.45 & 3.3 & 1.050 & -0.570 \\
\hline $4 \mathrm{H}-7$ & 61 & 34.31 & 34.56 & 0.8394 & 4.08 & 0.8647 & 3.88 & 5.50 & $\mathrm{k}_{1.079}$ & 57.61 & 57.61 & 1.9 & 1.329 & ${ }^{j}-1.020$ \\
\hline $5 \mathrm{H}-1$ & 1 & 34.31 & 34.56 & 0.8394 & 4.08 & 0.8647 & 3.88 & & & 59.98 & & 2.8 & & -0.470 \\
\hline $5 \mathrm{H}-1$ & 21 & 34.51 & 34.76 & 0.8442 & 4.12 & 0.8703 & 3.60 & 3.46 & 0.884 & 59.96 & 59.96 & 6.3 & & -0.600 \\
\hline $5 \mathrm{H}-1$ & 41 & 34.71 & 34.96 & 0.8491 & 4.12 & 0.8758 & 3.60 & 5.00 & 1.027 & 55.59 & 55.59 & 3.4 & & -0.090 \\
\hline $5 \mathrm{H}-1$ & 61 & 34.91 & 35.16 & 0.8539 & 4.12 & 0.8814 & 4.65 & 5.46 & 1.089 & 63.47 & 63.47 & 6.2 & 0.810 & -0.110 \\
\hline $5 \mathrm{H}-1$ & 81 & 35.11 & 35.36 & 0.8588 & 4.08 & 0.8844 & 6.67 & 3.88 & 1.086 & 68.60 & 68.60 & 2.0 & 1.082 & -0.200 \\
\hline $5 \mathrm{H}-1$ & 101 & 35.31 & 35.56 & 0.8637 & 4.12 & 0.8874 & 6.56 & 3.54 & 1.031 & 65.71 & 65.71 & 3.3 & 1.322 & -0.770 \\
\hline $5 \mathrm{H}-1$ & 121 & 35.51 & 35.76 & 0.8685 & 4.12 & 0.8905 & 6.56 & 3.08 & 1.012 & 68.07 & 68.07 & 5.7 & 0.979 & -0.690 \\
\hline $5 \mathrm{H}-1$ & 141 & 35.71 & 35.96 & 0.8734 & 4.12 & 0.8935 & 6.67 & 2.70 & 0.985 & 72.87 & 72.87 & 6.8 & 0.734 & -0.670 \\
\hline $5 \mathrm{H}-2$ & 11 & 35.91 & 36.16 & 0.8782 & 4.12 & 0.8965 & 6.67 & 3.14 & 0.950 & 72.16 & 72.16 & 2.2 & 1.130 & -0.570 \\
\hline $5 \mathrm{H}-2$ & 31 & 36.11 & 36.36 & 0.8831 & 4.08 & 0.8995 & 5.06 & 3.88 & 1.031 & 66.04 & 66.04 & 2.1 & & -0.410 \\
\hline $5 \mathrm{H}-2$ & 51 & 36.31 & 36.56 & 0.8880 & 4.12 & 0.9044 & 4.08 & 2.66 & 0.994 & 70.01 & 70.01 & 2.7 & 1.330 & \\
\hline $5 \mathrm{H}-2$ & 71 & 36.51 & 36.76 & 0.8928 & 4.12 & 0.9093 & 4.08 & 0.86 & 0.943 & 80.56 & 80.56 & 9.5 & & -1.180 \\
\hline $5 \mathrm{H}-2$ & 91 & 36.71 & 36.96 & 0.8977 & 4.12 & 0.9142 & 4.08 & 3.80 & 0.982 & 66.35 & 66.35 & 5.8 & 0.839 & -0.605 \\
\hline $5 \mathrm{H}-2$ & 111 & 36.91 & 37.16 & 0.9025 & 4.12 & 0.9191 & 3.60 & 4.08 & 1.046 & 67.78 & 67.78 & 3.4 & 1.093 & -0.530 \\
\hline $5 \mathrm{H}-2$ & 131 & 37.11 & 37.36 & 0.9074 & 4.12 & 0.9253 & 2.92 & 2.90 & 1.062 & 70.99 & 70.99 & 4.7 & & -0.450 \\
\hline $5 \mathrm{H}-3$ & 1 & 37.31 & 37.56 & 0.9122 & 4.12 & 0.9328 & 2.67 & 4.28 & 0.981 & 62.50 & 62.50 & 7.9 & & -0.690 \\
\hline $5 \mathrm{H}-3$ & 21 & 37.51 & 37.76 & 0.9171 & 4.08 & 0.9403 & 2.67 & 3.58 & 0.994 & 68.09 & 68.09 & 9.8 & 0.722 & -1.220 \\
\hline $5 \mathrm{H}-3$ & 41 & 37.71 & 37.96 & 0.9220 & 4.12 & 0.9478 & 2.86 & 3.38 & 0.961 & 67.18 & 67.18 & 9.9 & 0.968 & $\mathrm{j}-0.820$ \\
\hline $5 \mathrm{H}-3$ & 61 & 37.91 & 38.16 & 0.9268 & 4.12 & 0.9543 & 3.08 & 3.22 & 0.994 & 67.71 & 67.71 & 7.3 & 1.485 & -1.110 \\
\hline $5 \mathrm{H}-3$ & 81 & 38.11 & 38.36 & 0.9317 & 4.12 & 0.9608 & 3.08 & 2.44 & 0.904 & 67.66 & 67.66 & 11.6 & 1.172 & -0.640 \\
\hline SH-3 & 101 & 38.31 & 38.56 & 0.9365 & 4.12 & 0.9673 & 3.25 & 4.58 & 1.048 & 60.92 & 60.92 & 9.6 & 0.936 & -0.690 \\
\hline $5 \mathrm{H}-3$ & 121 & 38.51 & 38.76 & 0.9414 & 4.12 & 0.9731 & 3.67 & 5.52 & 1.122 & 58.27 & 58.27 & 7.4 & 0.791 & -0.860 \\
\hline $5 \mathrm{H}-3$ & 141 & 38.71 & 38.96 & 0.9462 & 4.12 & 0.9782 & 3.92 & 6.82 & 1.109 & 54.72 & 54.72 & 2.6 & 0.681 & -0.630 \\
\hline $5 \mathrm{H}-4$ & 11 & 38.91 & 39.16 & 0.9511 & 4.08 & 0.9833 & 3.92 & 4.14 & 0.943 & 61.53 & 61.53 & 6.4 & 0.911 & \\
\hline $5 \mathrm{H}-4$ & 31 & 39.11 & 39.36 & 0.9560 & 4.12 & 0.9884 & 5.48 & 2.50 & 0.959 & 74.59 & 74.59 & 13.0 & 1.036 & -1.320 \\
\hline $5 \mathrm{H}-4$ & 51 & 39.31 & 39.56 & 0.9608 & 4.12 & 0.9906 & 8.89 & 3.32 & 0.904 & 63.99 & 63.99 & 9.7 & 0.830 & -0.770 \\
\hline $5 \mathrm{H}-4$ & 71 & 39.51 & 39.76 & 0.9657 & 4.12 & 0.9929 & 8.89 & 2.94 & 0.924 & 70.82 & 70.82 & 14.6 & 0.886 & -0.630 \\
\hline $5 \mathrm{H}-4$ & 91 & 39.71 & 39.96 & 0.9705 & 4.12 & 0.9951 & 9.09 & 4.90 & 1.066 & 63.95 & 63.95 & 7.8 & & -0.400 \\
\hline $5 \mathrm{H}-4$ & 111 & 39.91 & 40.16 & 0.9754 & 4.08 & 0.9973 & 9.09 & 4.48 & 1.039 & 66.20 & 66.20 & 8.2 & 0.753 & -0.400 \\
\hline $5 \mathrm{H}-4$ & 131 & 40.11 & 40.36 & 0.9803 & 3.64 & 0.9995 & 8.51 & 2.82 & 0.944 & 73.43 & 73.43 & 17.4 & 1.247 & -0.480 \\
\hline $5 \mathrm{H}-5$ & 1 & 40.31 & 40.56 & 0.9864 & 3.28 & 1.0020 & 8.89 & 4.30 & 1.020 & 62.99 & 62.99 & 19.3 & 1.373 & -0.280 \\
\hline $5 \mathrm{H}-5$ & 21 & 40.51 & 40.76 & 0.9925 & 3.31 & 1.0040 & 10.00 & 6.28 & 1.100 & 54.64 & 54.64 & 10.4 & 1.001 & -0.050 \\
\hline $5 \mathrm{H}-5$ & 41 & 40.71 & 40.96 & 0.9985 & 3.20 & & & 5.72 & 1.039 & 60.86 & 60.86 & 11.5 & 0.953 & -0.200 \\
\hline $5 \mathrm{H}-5$ & 61 & 40.91 & 41.16 & 1.0050 & 3.20 & & & 6.10 & 1.086 & 56.92 & 56.92 & 7.4 & 0.707 & -0.360 \\
\hline $5 \mathrm{H}-5$ & 81 & 41.11 & 41.36 & 1.0110 & 3.33 & & & 4.48 & 1.079 & 66.52 & 66.52 & 6.6 & 0.774 & -0.720 \\
\hline $5 \mathrm{H}-5$ & 101 & 41.31 & 41.56 & 1.0170 & 3.33 & & & 3.34 & 1.039 & 73.46 & 73.46 & 8.5 & 0.735 & -0.660 \\
\hline $5 \mathrm{H}-5$ & 121 & 41.51 & 41.76 & 1.0230 & 3.33 & & & 3.62 & 1.044 & 69.28 & 69.28 & 4.1 & 0.880 & -0.640 \\
\hline $5 \mathrm{H}-5$ & 141 & 41.71 & 41.96 & 1.0290 & 3.33 & & & 2.88 & 1.032 & 69.68 & 69.68 & 6.6 & 0.907 & -1.100 \\
\hline $5 \mathrm{H}-6$ & 11 & 41.91 & 42.16 & 1.0350 & 3.33 & & & 3.10 & 0.982 & 72.96 & 72.96 & 9.5 & 0.889 & -0.690 \\
\hline $5 \mathrm{H}-6$ & 31 & 42.11 & 42.36 & 1.0410 & 3.33 & & & 3.24 & 0.970 & 67.68 & 67.68 & 9.3 & 1.188 & -0.380 \\
\hline $5 \mathrm{H}-6$ & 51 & 42.31 & 42.56 & 1.0470 & 3.33 & & & 2.28 & 0.950 & 73.94 & 73.94 & 15.3 & 0.912 & -0.960 \\
\hline $5 \mathrm{H}-6$ & 71 & 42.51 & 42.76 & 1.0530 & 3.33 & & & 3.54 & 0.986 & 70.36 & 70.36 & 14.4 & 1.178 & -0.300 \\
\hline $5 \mathrm{H}-6$ & 91 & 42.71 & 42.96 & 1.0590 & 3.33 & & & 3.58 & 1.023 & 65.64 & 65.64 & 12.5 & 1.047 & -0.190 \\
\hline $5 \mathrm{H}-6$ & 111 & 42.91 & 43.16 & 1.0650 & 3.33 & & & 3.26 & 1.064 & 68.43 & 68.43 & 8.8 & 0.972 & -0.630 \\
\hline $5 \mathrm{H}-6$ & 131 & 43.11 & 43.36 & 1.0710 & 3.08 & & & 3.68 & 1.032 & 67.70 & 67.70 & 12.1 & 0.960 & -0.510 \\
\hline $5 \mathrm{H}-7$ & 1 & 43.31 & 43.56 & 1.0780 & 3.08 & & & 3.90 & $k_{1} .073$ & 68.98 & 68.98 & 7.8 & 1.183 & -0.370 \\
\hline $5 \mathrm{H}-7$ & 21 & 43.51 & 43.76 & 1.0840 & 3.33 & & & 4.72 & $\mathrm{k}_{1.006}$ & 63.30 & 63.30 & 8.8 & 0.821 & -0.370 \\
\hline \multirow[t]{5}{*}{$5 \mathrm{H}-7$} & 41 & 43.71 & 43.96 & 1.0900 & 3.46 & & & 2.02 & $\mathrm{k}_{1.059}$ & 78.67 & .78 .67 & 6.9 & 1.034 & -0.830 \\
\hline & & & 44.21 & 1.0970 & 3.46 & & & $\mathrm{k}_{1.66}$ & $k_{0.985}$ & & ${ }^{\mathrm{i}} 78.78$ & & & \\
\hline & & & 44.41 & 1.1030 & 3.33 & & & $\mathrm{k}_{2.50}$ & $k_{0.958}$ & & $i_{73.92}$ & & & \\
\hline & & & 44.61 & 1.1090 & 3.33 & & & $k_{3.46}$ & $\mathrm{k}_{1.113}$ & & ${ }^{i} 68.35$ & & & \\
\hline & & & 44.81 & 1.1150 & 3.08 & & & $\mathrm{k}_{5.78}$ & $\mathrm{k}_{1.140}$ & & ${ }^{\mathrm{i}}{ }_{54.91}$ & & & \\
\hline $6 \mathrm{H}-1$ & 1 & 43.91 & 45.01 & 1.1220 & 3.08 & & & $\mathrm{k}_{5.58}$ & $\mathrm{k}_{1.147}$ & 56.67 & 56.67 & 10.0 & 0.920 & -0.170 \\
\hline $6 \mathrm{H}-1$ & 21 & 44.11 & 45.21 & 1.1280 & 3.33 & & & 4.90 & 1.069 & 60.79 & 60.79 & 8.3 & 1.045 & -0.390 \\
\hline
\end{tabular}


Appendix (continued).

\begin{tabular}{|c|c|c|c|c|c|c|c|c|c|c|c|c|c|c|}
\hline $\begin{array}{l}\text { Core, } \\
\text { section }\end{array}$ & $\begin{array}{l}\text { Section } \\
\text { depth } \\
\text { (cm) }\end{array}$ & $\begin{array}{l}\text { ODP } \\
\text { depth } \\
\text { (m) }\end{array}$ & $\begin{array}{l}\text { Composite }^{\mathrm{a}} \\
\text { depth } \\
\text { (m) }\end{array}$ & $\begin{array}{l}\text { Ship }^{\text {b }} \\
\text { age } \\
\text { (m.y.) }\end{array}$ & $\begin{array}{c}\text { Ship } \\
\text { sed. rate } \\
\text { (cm/k.y.) }\end{array}$ & $\begin{array}{l}\text { Isotope }^{c} \\
\text { age } \\
\text { (m.y.) }\end{array}$ & $\begin{array}{l}\text { Isotope } \\
\text { sed. rate } \\
\text { (cm/k.y.) }\end{array}$ & $\begin{array}{l}\text { Composite }{ }^{d} \\
\text { susceptibility } \\
\left(10^{-6} \mathrm{cgs}\right)\end{array}$ & $\begin{array}{c}\text { Composite }^{e} \\
\text { density } \\
\left(\mathrm{g} / \mathrm{cm}^{3}\right)\end{array}$ & $\begin{array}{c}\mathrm{CaCO}_{3} \\
(\%)\end{array}$ & $\begin{array}{c}\text { Composite } \\
\mathrm{CaCO}_{3}^{\mathrm{f}} \\
(\%)\end{array}$ & $\begin{array}{l}>150 \\
\mu \mathrm{m} \\
(\%)\end{array}$ & $\begin{array}{c}\text { C-org } \\
(\%)\end{array}$ & $\begin{array}{l}\delta^{18} \mathrm{O} \\
(\% 0)\end{array}$ \\
\hline $6 \mathrm{H}-1$ & 41 & 44.31 & 45.41 & 1.1340 & 3.33 & & & 5.18 & 1.031 & 62.96 & 62.96 & 7.1 & 0.721 & -0.490 \\
\hline $6 \mathrm{H}-1$ & 61 & 44.51 & 45.61 & 1.1400 & 3.33 & & & 4.76 & 1.070 & 60.96 & 60.96 & 3.5 & 1.276 & -0.340 \\
\hline $6 \mathrm{H}-1$ & 81 & 44.71 & 45.81 & 1.1460 & 3.33 & & & 2.72 & 1.012 & 72.88 & 72.88 & 9.9 & 1.602 & -0.490 \\
\hline $6 \mathrm{H}-1$ & 101 & 44.91 & 46.01 & 1.1520 & 3.33 & & & 3.72 & 0.997 & 63.38 & 63.38 & 11.3 & 1.054 & -0.640 \\
\hline $6 \mathrm{H}-1$ & 121 & 45.11 & 46.21 & 1.1580 & 3.33 & & & 4.92 & 1.012 & 56.44 & 56.44 & 8.3 & 1.288 & -0.360 \\
\hline $6 \mathrm{H}-1$ & 141 & 45.31 & 46.41 & 1.1640 & 3.33 & & & 5.20 & 1.050 & 57.42 & 57.42 & 9.8 & 0.802 & ${ }^{j}-0.020$ \\
\hline $6 \mathrm{H}-2$ & 11 & 45.51 & 46.61 & 1.1700 & 3.33 & & & 4.66 & 1.021 & 59.94 & 59.94 & 9.6 & 0.725 & -0.270 \\
\hline $6 \mathrm{H}-2$ & 31 & 45.71 & 46.81 & 1.1760 & 3.33 & & & 5.78 & 1.048 & 54.90 & 54.90 & 3.7 & 0.636 & -0.450 \\
\hline $6 \mathrm{H}-2$ & 51 & 45.91 & 47.01 & 1.1820 & 3.33 & & & 4.24 & 0.994 & 60.67 & 60.67 & 5.0 & 0.715 & -0.660 \\
\hline $6 \mathrm{H}-2$ & 71 & 46.11 & 47.21 & 1.1880 & 3.33 & & & 1.98 & 0.998 & 74.98 & 74.98 & 11.9 & 0.863 & -0.900 \\
\hline $6 \mathrm{H}-2$ & 91 & 46.31 & 47.41 & 1.1940 & 3.08 & & & 3.04 & 0.984 & 66.40 & 66.40 & 4.8 & 0.704 & -0.730 \\
\hline $6 \mathrm{H}-2$ & 111 & 46.51 & 47.61 & 1.2010 & 3.08 & & & 4.64 & 0.998 & 53.75 & 53.75 & 3.7 & 0.800 & -0.730 \\
\hline $6 \mathrm{H}-2$ & 131 & 46.71 & 47.81 & 1.2070 & 3.33 & & & 5.22 & 1.059 & 56.73 & 56.73 & 8.0 & 0.793 & -0.540 \\
\hline $6 \mathrm{H}-3$ & 1 & 46.91 & 48.01 & 1.2130 & 3.33 & & & 4.78 & 1.097 & 58.44 & 58.44 & 7.6 & 0.879 & -0.690 \\
\hline $6 \mathrm{H}-3$ & 21 & 47.11 & 48.21 & 1.2190 & 3.33 & & & 6.80 & 1.122 & 53.14 & 53.14 & 2.9 & 0.818 & -0.490 \\
\hline $6 \mathrm{H}-3$ & 41 & 47.31 & 48.41 & 1.2250 & 3.33 & & & 2.18 & 0.986 & 77.30 & 77.30 & 6.4 & 0.526 & -1.470 \\
\hline $6 \mathrm{H}-3$ & 61 & 47.51 & 48.61 & 1.2310 & 3.33 & & & 2.62 & 1.001 & 71.22 & 71.22 & 8.6 & 0.758 & -1.020 \\
\hline $6 \mathrm{H}-3$ & 81 & 47.71 & 48.81 & 1.2370 & 3.33 & & & 2.40 & 0.971 & 69.98 & 69.98 & 7.1 & 1.072 & -0.630 \\
\hline $6 \mathrm{H}-3$ & 101 & 47.91 & 49.01 & 1.2430 & 3.33 & & & 1.96 & 0.888 & 63.84 & 63.84 & 8.8 & 1.120 & -0.830 \\
\hline $6 \mathrm{H}-3$ & 121 & 48.11 & 49.21 & 1.2490 & 3.33 & & & 3.52 & 0.908 & 71.65 & 71.65 & 14.1 & 1.090 & -0.490 \\
\hline $6 \mathrm{H}-3$ & 141 & 48.31 & 49.41 & 1.2550 & 3.33 & & & 4.36 & 1.036 & 61.23 & 61.23 & 5.7 & 1.259 & -0.410 \\
\hline $6 \mathrm{H}-4$ & 11 & 48.51 & 49.61 & 1.2610 & 3.33 & & & 2.76 & 0.967 & 68.43 & 68.43 & 7.1 & 1.195 & -0.650 \\
\hline $6 \mathrm{H}-4$ & 31 & 48.71 & 49.81 & 1.2670 & 3.33 & & & 1.86 & 0.915 & 71.04 & 71.04 & 10.7 & 1.232 & -0.940 \\
\hline $6 \mathrm{H}-4$ & 51 & 48.91 & 50.01 & 1.2730 & 3.08 & & & 2.64 & 0.940 & 66.64 & 66.64 & 9.6 & 1.361 & -0.750 \\
\hline $6 \mathrm{H}-4$ & 71 & 49.11 & 50.21 & 1.2800 & 3.08 & & & 6.26 & 1.006 & 52.57 & 52.57 & 3.1 & 0.880 & -0.390 \\
\hline $6 \mathrm{H}-4$ & 91 & 49.31 & 50.41 & 1.2860 & 3.33 & & & 4.32 & 1.033 & 57.69 & 57.69 & 5.2 & 0.910 & -0.540 \\
\hline $6 \mathrm{H}-4$ & 111 & 49.51 & 50.61 & 1.2920 & 3.33 & & & 3.48 & 0.985 & 66.14 & 66.14 & 4.8 & 1.005 & -0.330 \\
\hline $6 \mathrm{H}-4$ & 131 & 49.71 & 50.81 & 1.2980 & 3.33 & & & 4.10 & 0.980 & 54.23 & 54.23 & 4.6 & 1.055 & -0.870 \\
\hline $6 \mathrm{H}-5$ & 1 & 49.91 & 51.01 & 1.3040 & 3.33 & & & 5.44 & 1.056 & 57.48 & 57.48 & 1.5 & 0.513 & -0.770 \\
\hline $6 \mathrm{H}-5$ & 21 & 50.11 & 51.21 & 1.3100 & 3.33 & & & 6.80 & 1.095 & 57.81 & 57.81 & 9.1 & 0.594 & -0.610 \\
\hline $6 \mathrm{H}-5$ & 41 & 50.31 & 51.41 & 1.3160 & 3.33 & & & 6.24 & 1.094 & 56.35 & 56.35 & 4.8 & 1.058 & -0.480 \\
\hline $6 \mathrm{H}-5$ & 61 & 50.51 & 51.61 & 1.3220 & 3.33 & & & 6.96 & 1.124 & 50.22 & 50.22 & 2.8 & 1.082 & -0.520 \\
\hline $6 \mathrm{H}-5$ & 81 & 50.71 & 51.81 & 1.3280 & 3.33 & & & 3.60 & 1.093 & 68.36 & 68.36 & 4.7 & 0.760 & -1.320 \\
\hline $6 \mathrm{H}-5$ & 101 & 50.91 & 52.01 & 1.3340 & 3.33 & & & 3.26 & 1.019 & 67.91 & 67.91 & 7.1 & 0.801 & -0.930 \\
\hline $6 \mathrm{H}-5$ & 121 & 51.11 & 52.21 & 1.3400 & 3.33 & & & 4.68 & 1.005 & 61.26 & 61.26 & 6.0 & 0.925 & -0.660 \\
\hline $6 \mathrm{H}-5$ & 141 & 51.31 & 52.41 & 1.3460 & 3.33 & & & 5.44 & 1.091 & 57.34 & 57.34 & 3.6 & 0.929 & -0.540 \\
\hline $6 \mathrm{H}-6$ & 11 & 51.51 & 52.61 & 1.3520 & 3.33 & & & 3.66 & 1.095 & 66.10 & 66.10 & 3.5 & 1.296 & -0.440 \\
\hline $6 \mathrm{H}-6$ & 31 & 51.71 & 52.81 & 1.3580 & 3.08 & & & 4.58 & 1.079 & 57.21 & 57.21 & 4.9 & 1.381 & -0.800 \\
\hline $6 \mathrm{H}-6$ & 51 & 51.91 & 53.01 & 1.3650 & 3.08 & & & 5.70 & 1.051 & 58.02 & 58.02 & 7.4 & 1.235 & -0.140 \\
\hline $6 \mathrm{H}-6$ & 71 & 52.11 & 53.21 & 1.3710 & 3.33 & & & 6.24 & 1.077 & 53.90 & 53.90 & 2.8 & 1.222 & -0.040 \\
\hline $6 \mathrm{H}-6$ & 91 & 52.31 & 53.41 & 1.3770 & 3.33 & & & 5.02 & 0.986 & 59.33 & 59.33 & 5.4 & 1.058 & -0.510 \\
\hline $6 \mathrm{H}-6$ & 111 & 52.51 & 53.61 & 1.3830 & 3.33 & & & 4.60 & 1.004 & 55.51 & 55.51 & 3.3 & 1.595 & -0.820 \\
\hline $6 \mathrm{H}-6$ & 131 & 52.71 & 53.81 & 1.3890 & 3.33 & & & 5.14 & 1.012 & 49.85 & 49.85 & 1.6 & 2.892 & \\
\hline $6 \mathrm{H}-7$ & 1 & 52.91 & 54.01 & 1.3950 & 3.33 & & & 4.92 & $k_{1.160}$ & 58.79 & 58.79 & 2.4 & 1.323 & -1.160 \\
\hline $6 \mathrm{H}-7$ & 21 & 53.11 & 54.21 & 1.4010 & 3.33 & & & 6.52 & $k_{1.025}$ & 50.42 & 50.42 & 2.1 & 1.429 & -0.560 \\
\hline $6 \mathrm{H}-7$ & 41 & 53.31 & 54.41 & 1.4070 & 3.33 & & & $\mathrm{k}_{3.24}$ & ${ }^{\mathrm{k}} 0.985$ & 68.33 & ${ }^{\mathrm{i}} 65.84$ & 3.7 & 1.263 & -1.140 \\
\hline $6 \mathrm{H}-7$ & 61 & 53.51 & 54.61 & 1.4130 & 3.33 & & & $k_{3.70}$ & $\mathrm{k}_{1.039}$ & 60.07 & i 63.61 & 3.3 & 1.171 & -0.560 \\
\hline & & & 54.81 & 1.4190 & 3.33 & & & $\mathrm{k}_{3.48}$ & $\mathrm{k}_{1.073}$ & & ${ }^{\mathrm{i}} 64.68$ & & & \\
\hline & & & 55.01 & 1.4250 & 3.33 & & & $\mathrm{k}_{3.84}$ & $\mathrm{k}_{1.100}$ & & ${ }^{1} 62.93$ & & & \\
\hline & & & 55.21 & 1.4310 & 3.33 & & & $k_{4.78}$ & $\mathrm{k}_{1.052}$ & & ${ }^{i} 58.37$ & & & \\
\hline & & & 55.41 & 1.4370 & 3.08 & & & $\mathrm{k}_{2.81}$ & $\mathrm{k}_{1.005}$ & & ${ }^{1} 67.93$ & & & \\
\hline & & & 55.61 & 1.4440 & 3.08 & & & $k_{3.80}$ & $\mathrm{k}_{0.951}$ & & $\mathrm{i}_{63.12}$ & & & \\
\hline & & & 55.81 & 1.4500 & 3.33 & & & $k_{4.46}$ & $\mathrm{k}_{1.100}$ & & $\mathrm{i}_{59.92}$ & & & \\
\hline & & & 56.01 & 1.4560 & 3.33 & & & $k_{5.84}$ & ${ }^{k} 0.971$ & & ${ }^{5} 53.22$ & & & \\
\hline $7 \mathrm{H}-1$ & 1 & 53.21 & 56.21 & 1.4620 & 3.33 & & & $k_{5} .40$ & $k_{1.025}$ & 54.34 & $i_{55.36}$ & 2.1 & 1.852 & 0.010 \\
\hline $7 \mathrm{H}-1$ & 21 & 53.41 & 56.41 & 1.4680 & 3.33 & & & $\mathrm{k}_{5.02}$ & 0.951 & 51.91 & $\mathrm{i}_{57.20}$ & 1.5 & 2.172 & -1.070 \\
\hline $7 \mathrm{H}-1$ & 41 & 53.61 & 56.61 & 1.4740 & 3.33 & & & 4.92 & 1.011 & 51.90 & í 57.69 & 2.5 & 1.674 & -0.920 \\
\hline $7 \mathrm{H}-1$ & 61 & 53.81 & 56.81 & 1.4800 & 3.33 & & & 6.96 & 1.023 & 45.76 & 45.76 & 2.9 & 1.127 & -0.295 \\
\hline $7 \mathrm{H}-1$ & 81 & 54.01 & 57.01 & 1.4860 & 3.33 & & & 9.46 & 1.059 & 32.51 & 32.51 & 1.0 & 1.566 & -0.560 \\
\hline $7 \mathrm{H}-1$ & 101 & 54.21 & 57.21 & 1.4920 & 3.33 & & & 7.20 & 1.098 & 49.66 & 49.66 & 1.7 & 1.208 & -0.130 \\
\hline $7 \mathrm{H}-1$ & 121 & 54.41 & 57.41 & 1.4980 & 3.33 & & & 6.74 & 1.157 & 44.30 & 44.30 & 2.0 & 1.441 & -0.450 \\
\hline $7 \mathrm{H}-1$ & 141 & 54.61 & 57.61 & 1.5040 & 3.33 & & & 5.06 & 1.082 & 57.95 & 57.95 & 4.0 & 1.144 & -0.650 \\
\hline $7 \mathrm{H}-2$ & 11 & 54.81 & 57.81 & 1.5100 & 3.33 & & & 6.58 & 1.067 & 52.01 & 52.01 & 4.7 & 0.896 & -0.460 \\
\hline $7 \mathrm{H}-2$ & 31 & 55.01 & 58.01 & 1.5160 & 3.08 & & & 5.86 & 1.124 & 61.26 & 61.26 & 4.2 & 0.887 & -0.500 \\
\hline $7 \mathrm{H}-2$ & 51 & 55.21 & 58.21 & 1.5230 & 3.08 & & & 4.22 & 1.054 & 61.21 & 61.21 & 3.0 & 1.074 & -1.250 \\
\hline $7 \mathrm{H}-2$ & 71 & 55.41 & 58.41 & 1.5290 & 3.33 & & & 3.76 & 1.036 & 61.86 & 61.86 & 4.2 & 0.862 & -1.030 \\
\hline $7 \mathrm{H}-2$ & 91 & 55.61 & 58.61 & 1.5350 & 3.33 & & & 4.10 & 1.056 & 61.77 & 61.77 & 3.8 & 1.193 & -0.670 \\
\hline $7 \mathrm{H}-2$ & 111 & 55.81 & 58.81 & 1.5410 & 3.33 & 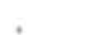 & & 7.04 & 1.133 & 46.89 & 46.89 & 4.2 & 0.820 & -0.310 \\
\hline $7 \mathrm{H}-2$ & 131 & 56.01 & 59.01 & 1.5470 & 3.33 & & & 6.94 & 1.145 & 47.91 & 47.91 & 1.4 & 1.322 & -0.390 \\
\hline $7 \mathrm{H}-3$ & 1 & 56.21 & 59.21 & 1.5530 & 3.33 & & & 4.90 & 1.170 & 51.13 & 51.13 & 1.0 & 1.344 & -0.230 \\
\hline $7 \mathrm{H}-3$ & 21 & 56.41 & 59.41 & 1.5590 & 3.33 & & & 4.62 & 1.016 & 65.03 & 65.03 & 3.7 & 1.088 & -0.990 \\
\hline $7 \mathrm{H}-3$ & 41 & 56.61 & 59.61 & 1.5650 & 3.33 & & & 5.66 & 0.986 & 52.76 & 52.76 & 1.4 & 1.491 & \\
\hline $7 \mathrm{H}-3$ & 61 & 56.81 & 59.81 & 1.5710 & 3.33 & & & 3.90 & 1.004 & 69.43 & 69.43 & 5.0 & 0.720 & -1.285 \\
\hline $7 \mathrm{H}-3$ & 81 & 57.01 & 60.01 & 1.5770 & 3.33 & & & 8.24 & 1.106 & 41.42 & 41.42 & 2.8 & 1.995 & -0.750 \\
\hline $7 \mathrm{H}-3$ & 101 & 57.21 & 60.21 & 1.5830 & 3.33 & & & 6.34 & 1.086 & 49.61 & 49.61 & 1.8 & 1.451 & -0.820 \\
\hline $7 \mathrm{H}-3$ & 121 & 57.41 & 60.41 & 1.5890 & 3.33 & & & 3.90 & 1.047 & 56.93 & 56.93 & 1.9 & 1.799 & -1.200 \\
\hline
\end{tabular}


Appendix (continued).

\begin{tabular}{|c|c|c|c|c|c|c|c|c|c|c|c|c|c|c|}
\hline $\begin{array}{l}\text { Core, } \\
\text { section }\end{array}$ & $\begin{array}{l}\text { Section } \\
\text { depth } \\
(\mathrm{cm})\end{array}$ & $\begin{array}{l}\text { ODP } \\
\text { depth } \\
\text { (m) }\end{array}$ & $\begin{array}{l}\text { Composite }^{\mathrm{a}} \\
\text { depth } \\
\text { (m) }\end{array}$ & $\begin{array}{l}\text { Ship }^{b} \\
\text { age } \\
\text { (m.y.) }\end{array}$ & $\begin{array}{c}\text { Ship } \\
\text { sed. rate } \\
\text { (cm/k.y.) }\end{array}$ & $\begin{array}{l}\text { Isotope }^{c} \\
\text { age } \\
\text { (m.y.) }\end{array}$ & $\begin{array}{l}\text { Isotope } \\
\text { sed. rate } \\
\text { (cm/k.y.) }\end{array}$ & $\begin{array}{c}\text { Composited } \\
\text { susceptibility } \\
\left(10^{-6} \mathrm{cgs}\right)\end{array}$ & $\begin{array}{c}\text { Composite }^{e} \\
\text { density } \\
\left(\mathrm{g} / \mathrm{cm}^{3}\right)\end{array}$ & $\begin{array}{c}\mathrm{CaCO}_{3} \\
(\%)\end{array}$ & $\begin{array}{c}\text { Composite }^{f} \\
\mathrm{CaCO}_{3} \\
(\%)\end{array}$ & $\begin{array}{l}>150 \\
\underset{\mu \mathrm{m}}{(\%)}\end{array}$ & $\begin{array}{c}\text { C-org } \\
(\%)\end{array}$ & $\begin{array}{l}\delta^{18} \mathrm{O} \\
(\%(\%))\end{array}$ \\
\hline $7 \mathrm{H}-3$ & 141 & 57.61 & 60.61 & 1.5950 & 3.08 & & & 2.56 & 1.025 & 65.65 & 65.65 & 2.3 & 1.401 & \\
\hline $7 \mathrm{H}-4$ & 11 & 57.81 & 60.81 & 1.6020 & 3.08 & & & 2.48 & 0.988 & 64.73 & 64.73 & 1.8 & 1.553 & -0.920 \\
\hline $7 \mathrm{H}-4$ & 31 & 58.01 & 61.01 & 1.6080 & 3.33 & & & $k_{3.10}$ & 0.907 & 65.97 & 65.97 & 3.0 & 1.111 & -0.820 \\
\hline $7 \mathrm{H}-4$ & 51 & 58.21 & 61.21 & 1.6140 & 3.33 & & & ${ }^{k} 3.90$ & 1.012 & 62.80 & 62.80 & 4.4 & 1.196 & \\
\hline 7H-4 & 71 & 58.41 & 61.41 & 1.6200 & 3.33 & & & $k_{5.74}$ & 1.075 & 59.75 & 59.75 & 1.8 & 1.777 & -0.430 \\
\hline $7 \mathrm{H}-4$ & 91 & 58.61 & 61.61 & 1.6260 & 3.33 & & & ${ }^{k} 3.86$ & 1.114 & 51.68 & 51.68 & 0.9 & 2.295 & \\
\hline $7 \mathrm{H}-4$ & 11 & 58.81 & 61.81 & 1.6320 & 3.33 & & & $\mathrm{k}_{3.66}$ & 1.048 & 60.26 & 60.26 & 0.8 & 1.829 & \\
\hline $7 \mathrm{H}-4$ & 131 & 59.01 & 62.01 & 1.6380 & 3.33 & & & $k_{3.46}$ & 1.027 & 61.23 & 61.23 & 2.5 & 1.459 & -1.250 \\
\hline 7H-5 & 1 & 59.21 & 62.21 & 1.6440 & 3.33 & & & 4.38 & 1.205 & 61.27 & 61.27 & 4.8 & 0.951 & -0.645 \\
\hline $7 \mathrm{H}-5$ & 21 & 59.41 & 62.41 & 1.6500 & 3.33 & & & 5.88 & 1.157 & 57.03 & 57.03 & 1.6 & 1.200 & -0.370 \\
\hline 7H-5 & 41 & 59.61 & 62.61 & 1.6560 & 3.33 & & & 3.60 & 1.104 & 68.87 & 68.87 & 1.4 & 1.235 & -0.740 \\
\hline $7 \mathrm{H}-5$ & 61 & 59.81 & 62.81 & 1.6620 & 3.33 & & & 2.62 & 1.054 & 71.64 & 71.64 & 2.5 & 1.430 & -1.130 \\
\hline 7H-5 & 81 & 60.01 & 63.01 & 1.6680 & 3.33 & & & 2.62 & 1.015 & 71.54 & 71.54 & 2.8 & 1.290 & \\
\hline $7 \mathrm{H}-5$ & 101 & 60.21 & 63.21 & 1.6740 & 3.33 & & & 5.20 & 1.071 & 55.96 & 55.96 & 0.9 & 1.406 & -1.160 \\
\hline 7H-5 & 121 & 60.41 & 63.41 & 1.6800 & 3.08 & & & 4.90 & 1.149 & 58.08 & 58.08 & 1.2 & 1.727 & -0.410 \\
\hline $7 \mathrm{H}-5$ & 141 & 60.61 & 63.61 & 1.6870 & 3.08 & & & 4.38 & 1.015 & 56.76 & 56.76 & 0.9 & 1.978 & -0.540 \\
\hline $7 \mathrm{H}-6$ & 11 & 60.81 & 63.81 & 1.6930 & 3.33 & & & 2.00 & 1.131 & 75.13 & 75.13 & 1.8 & 1.436 & \\
\hline $7 \mathrm{H}-6$ & 31 & 61.01 & 64.01 & 1.6990 & 3.33 & & & 2.42 & 1.042 & 68.19 & 68.19 & 1.4 & 1.528 & \\
\hline $7 \mathrm{H}-6$ & 51 & 61.21 & 64.21 & 1.7050 & 3.33 & & & 2.34 & 1.012 & 66.64 & 66.64 & 2.0 & 2.059 & -0.420 \\
\hline $7 \mathrm{H}-6$ & 71 & 61.41 & 64.41 & 1.7110 & 3.33 & & & 2.72 & 1.083 & 68.11 & 68.11 & 2.8 & 1.886 & -0.610 \\
\hline $7 \mathrm{H}-6$ & 91 & 61.61 & 64.61 & 1.7170 & 3.33 & & & 2.78 & 1.063 & 65.88 & 65.88 & 2.4 & 1.665 & -0.920 \\
\hline $7 \mathrm{H}-6$ & 111 & 61.81 & 64.81 & 1.7230 & 3.33 & & & 2.56 & 0.981 & 64.60 & 64.60 & 1.7 & 2.288 & -0.950 \\
\hline $7 \mathrm{H}-6$ & 131 & 62.01 & 65.01 & 1.7290 & 3.33 & & & 4.66 & 1.090 & 58.72 & 58.72 & 1.4 & 1.876 & -0.270 \\
\hline $7 \mathrm{H}-7$ & 1 & 62.21 & 65.21 & 1.7350 & 3.33 & & & 5.14 & 1.105 & 54.08 & 54.08 & 1.7 & 1.628 & -0.770 \\
\hline $7 \mathrm{H}-7$ & 21 & 62.41 & 65.41 & 1.7410 & 3.33 & & & 5.58 & $\mathrm{k}_{1.083}$ & 60.43 & 60.43 & 2.7 & 1.560 & -0.310 \\
\hline $7 \mathrm{H}-7$ & 41 & 62.61 & 65.61 & 1.7470 & 3.33 & & & 7.68 & $\mathrm{k}_{1.160}$ & 45.84 & 45.84 & 0.5 & 2.452 & -0.310 \\
\hline \multirow[t]{3}{*}{$7 \mathrm{H}-7$} & 61 & 62.81 & 65.81 & 1.7530 & 3.21 & & & 4.00 & $\mathrm{k}_{1.073}$ & 69.91 & 69.91 & 1.9 & 1.391 & \\
\hline & & & 66.06 & 1.7610 & 3.21 & & & $k_{5.88}$ & $\mathrm{k}_{1.133}$ & & ${ }^{\mathrm{i}} 56.93$ & & & \\
\hline & & & 66.26 & 1.7670 & 3.33 & & & $\mathrm{k}_{4.40}$ & $\mathrm{k}_{1.046}$ & & $\mathrm{i}_{62.86}$ & & & \\
\hline $8 \mathrm{H}-1$ & 1 & 62.91 & 66.46 & 1.7730 & 3.33 & & & $k_{7} .62$ & 1.147 & 57.08 & 57.08 & 1.8 & 2.183 & -0.760 \\
\hline $8 \mathrm{H}-1$ & 21 & 63.11 & 66.66 & 1.7790 & 3,33 & & & 4.18 & 1.008 & 63.49 & 63.49 & & 2.454 & \\
\hline $8 \mathrm{H}-1$ & 41 & 63.31 & 66.86 & 1.7850 & 3.33 & & & 1.30 & 1.094 & 81.46 & 81.46 & 3.4 & 1.772 & -1.140 \\
\hline $8 \mathrm{H}-1$ & 61 & 63.51 & 67.06 & 1.7910 & 3.33 & & & 2.16 & 1.097 & 76.45 & 76.45 & 3.4 & 1.476 & -0.800 \\
\hline $8 \mathrm{H}-1$ & 81 & 63.71 & 67.26 & 1.7970 & 3.08 & & & 3.50 & 1.113 & 66.37 & 66.37 & 2.1 & 1.394 & -0.330 \\
\hline $8 \mathrm{H}-1$ & 101 & 63.91 & 67.46 & 1.8040 & 3.08 & & & 3.36 & 1.110 & 68.60 & 68.60 & 1.1 & 1.824 & -0.520 \\
\hline $8 \mathrm{H}-1$ & 121 & 64.11 & 67.66 & 1.8100 & 3.33 & & & 2.86 & 1.033 & 70.53 & 70.53 & 1.2 & 1.860 & -0.690 \\
\hline $8 \mathrm{H}-1$ & 141 & 64.31 & 67.86 & 1.8160 & 3.33 & & & 2.38 & 1.042 & 72.51 & 72.51 & 2.6 & 1.283 & -0.220 \\
\hline $8 \mathrm{H}-2$ & 11 & 64.51 & 68.06 & 1.8220 & 3.33 & & & 3.58 & 1.145 & 63.29 & 63.29 & 2.0 & 1.425 & -0.350 \\
\hline $8 \mathrm{H}-2$ & 31 & 64.71 & 68.26 & 1.8280 & 3.33 & & & 3.08 & 1.058 & 71.57 & 71.57 & 1.7 & 1.425 & -0.180 \\
\hline $8 \mathrm{H}-2$ & 51 & 64.91 & 68.46 & 1.8340 & 3.33 & & & 3.52 & 1.048 & 69.37 & 69.37 & 1.0 & 1.723 & -0.340 \\
\hline $8 \mathrm{H}-2$ & 71 & 65.11 & 68.66 & 1.8400 & 3.33 & & & 3.98 & 1.033 & 63.95 & 63.95 & 0.9 & 1.950 & \\
\hline $8 \mathrm{H}-2$ & 91 & 65.31 & 68.86 & 1.8460 & 3.33 & & & 3.92 & 1.062 & 60.53 & 60.53 & 1.4 & 1.372 & \\
\hline $8 \mathrm{H}-2$ & 111 & 65.51 & 69.06 & 1.8520 & 3.33 & & & 1.40 & 1.160 & 80.93 & 80.93 & 3.8 & 1.758 & -0.860 \\
\hline $8 \mathrm{H}-2$ & 131 & 65.71 & 69.26 & 1.8580 & 3.33 & & & 5.06 & 1.054 & 70.38 & 70.38 & 1.3 & 0.954 & -0.740 \\
\hline $8 \mathrm{H}-3$ & 1 & 65.91 & 69.46 & 1.8640 & 3.33 & & & 6.14 & 1.152 & 67.89 & 67.89 & 2.3 & 1.594 & \\
\hline $8 \mathrm{H}-3$ & 21 & 66.11 & 69.66 & 1.8700 & 3.33 & & & 3.40 & 1.055 & 52.33 & 52.33 & 0.6 & 1.756 & $\mathrm{j}_{-}-0.480$ \\
\hline $8 \mathrm{H}-3$ & 41 & 66.31 & 69.86 & 1.8760 & 3.08 & & & 4.62 & 1.036 & 62.87 & 62.87 & 3.4 & 1.907 & -0.780 \\
\hline $8 \mathrm{H}-3$ & 61 & 66.51 & 70.06 & 1.8830 & 3.08 & & & 4.90 & 0.990 & 56.04 & 56.04 & 1.6 & 1.737 & -0.510 \\
\hline $8 \mathrm{H}-3$ & 81 & 66.71 & 70.26 & 1.8890 & 3.33 & & & 2.34 & 1.019 & 68.69 & 68.69 & 3.0 & 1.885 & -0.940 \\
\hline $8 \mathrm{H}-3$ & 101 & 66.91 & 70.46 & 1.8950 & 3.33 & & & 3.70 & 1.038 & 69.06 & 69.06 & 6.5 & 1.372 & -0.850 \\
\hline $8 \mathrm{H}-3$ & 121 & 67.11 & 70.66 & 1.9010 & 3.33 & & & 4.70 & 1.064 & 61.21 & 61.21 & 1.2 & 1.933 & -0.300 \\
\hline $8 \mathrm{H}-3$ & 141 & 67.31 & 70.86 & 1.9070 & 3.33 & & & 4.84 & 1.144 & 57.77 & 57.77 & 0.9 & 1.525 & \\
\hline $8 \mathrm{H}-4$ & 11 & 67.51 & 71.06 & 1.9130 & 3.33 & & & 2.48 & 1.002 & 74.25 & 74.25 & 1.9 & 1.930 & \\
\hline $8 \mathrm{H}-4$ & 31 & 67.71 & 71.26 & 1.9190 & 3.33 & & & 2.16 & 0.961 & 73.61 & 73.61 & 2.5 & 1.774 & -0.700 \\
\hline $8 \mathrm{H}-4$ & 51 & 67.91 & 71.46 & 1.9250 & 3.33 & & & 2.74 & 1.021 & 69.11 & 69.11 & 2.9 & 1.872 & -0.730 \\
\hline $8 \mathrm{H}-4$ & 71 & 68.11 & 71.66 & 1.9310 & 3.33 & & & 2.66 & 1.081 & 66.53 & 66.53 & 1.3 & 1.962 & -0.610 \\
\hline $8 \mathrm{H}-4$ & 91 & 68.31 & 71.86 & 1.9370 & 3.33 & & & 3.12 & 1.066 & 66.89 & 66.89 & 2.4 & 1.923 & -0.520 \\
\hline $8 \mathrm{H}-4$ & 111 & 68.51 & 72.06 & 1.9430 & 3.33 & & & 4.08 & 1.083 & 62.83 & 62.83 & 1.8 & 2.311 & -0.800 \\
\hline $8 \mathrm{H}-4$ & 131 & 68.71 & 72.26 & 1.9490 & 3.33 & & & 5.94 & 1.176 & 54.13 & 54.13 & 1.2 & 1.642 & -0.300 \\
\hline $8 \mathrm{H}-5$ & 1 & 68.91 & 72.46 & 1.9550 & 3.33 & & & 3.16 & 1.112 & 68.44 & 68.44 & 3.4 & 1.613 & -0.310 \\
\hline $8 \mathrm{H}-5$ & 21 & 69.11 & 72.66 & 1.9610 & 3.08 & & & 2.62 & 1.137 & 72.89 & 72.89 & 2.3 & 1.681 & -0.820 \\
\hline $8 \mathrm{H}-5$ & 41 & 69.31 & 72.86 & 1.9680 & 3.08 & & & 4.04 & 1.066 & 62.38 & 62.38 & 0.9 & 1.827 & -0.880 \\
\hline $8 \mathrm{H}-5$ & 61 & 69.51 & 73.06 & 1.9740 & 3.33 & & & 3.10 & 1.025 & 65.93 & 65.93 & 2.0 & 2.296 & -1.060 \\
\hline $8 \mathrm{H}-5$ & 81 & 69.71 & 73.26 & 1.9800 & 3.33 & & & 5.52 & 1.093 & 59.35 & 59.35 & 2.8 & & -0.490 \\
\hline $8 \mathrm{H}-5$ & 101 & 69.91 & 73.46 & 1.9860 & 3.33 & & & 6.78 & 1.178 & 52.82 & 52.82 & 0.9 & 1.321 & -0.720 \\
\hline $8 \mathrm{H}-5$ & 121 & 70.11 & 73.66 & 1.9920 & 3.33 & & & 3.24 & 1.060 & 68.84 & 68.84 & 2.5 & 1.284 & -1.010 \\
\hline $8 \mathrm{H}-5$ & 141 & 70.31 & 73.86 & 1.9980 & 3.33 & & & 1.90 & 1.117 & 73.86 & 73.86 & 4.2 & 1.306 & -1.010 \\
\hline $8 \mathrm{H}-6$ & 11 & 70.51 & 74.06 & 2.0040 & 3.33 & & & 2.50 & 1.071 & 70.67 & 70.67 & 2.6 & 1.596 & \\
\hline $8 \mathrm{H}-6$ & 31 & 70.71 & 74.26 & 2.0100 & 3.33 & & & 2.98 & 1.157 & 72.10 & 72.10 & 3.4 & 1.002 & -0.470 \\
\hline $8 \mathrm{H}-6$ & 51 & 70.91 & 74.46 & 2.0160 & 3.33 & & & 2.80 & 1.083 & 74.74 & 74.74 & 3.0 & 1.197 & -0.260 \\
\hline $8 \mathrm{H}-6$ & 71 & 71.11 & 74.66 & 2.0220 & 3.33 & & & 2.10 & 1.116 & 73.28 & 73.28 & 2.5 & 1.225 & -0.430 \\
\hline $8 \mathrm{H}-6$ & 91 & 71.31 & 74.86 & 2.0280 & 3.33 & & & 1.58 & 1.095 & 75.95 & 75.95 & 2.6 & 1.490 & -0.780 \\
\hline $8 \mathrm{H}-6$ & 111 & 71.51 & 75.06 & 2.0340 & 3.33 & & & 1.42 & 1.083 & 77.14 & 77.14 & 7.2 & 1.446 & -0.560 \\
\hline $8 \mathrm{H}-6$ & 131 & 71.71 & 75.26 & 2.0400 & 3.08 & & & 1.50 & 1.140 & 78.06 & 78.06 & 2.4 & 1.396 & -0.520 \\
\hline $8 \mathrm{H}-7$ & 1 & 71.91 & 75.46 & 2.0470 & 3.08 & & & 1.46 & $\mathrm{k}_{1.086}$ & 76.87 & 76.87 & 2.5 & 1.288 & -0.750 \\
\hline $8 \mathrm{H}-7$ & 21 & 72.11 & 75.66 & 2.0530 & 3.33 & & & 1.98 & $\mathrm{k}_{1.012}$ & 72.29 & 72.29 & 1.9 & 1.135 & -0.910 \\
\hline
\end{tabular}


Appendix (continued).

\begin{tabular}{|c|c|c|c|c|c|c|c|c|c|c|c|c|c|c|}
\hline $\begin{array}{l}\text { Core, } \\
\text { section }\end{array}$ & $\begin{array}{l}\text { Section } \\
\text { depth } \\
(\mathrm{cm})\end{array}$ & $\begin{array}{l}\text { ODP } \\
\text { depth } \\
\text { (m) }\end{array}$ & $\begin{array}{l}\text { Composite }{ }^{a} \\
\text { depth } \\
\text { (m) }\end{array}$ & $\begin{array}{l}\text { Ship }{ }^{b} \\
\text { age } \\
\text { (m.y.) }\end{array}$ & $\begin{array}{l}\text { Ship } \\
\text { sed. rate } \\
\text { (cm/k.y.) }\end{array}$ & $\begin{array}{l}\text { Isotope }^{c} \\
\text { age } \\
\text { (m.y.) }\end{array}$ & $\begin{array}{l}\text { Isotope } \\
\text { sed. rate } \\
\text { (cm/k.y.) }\end{array}$ & $\begin{array}{l}\text { Composite } \\
\text { susceptibility } \\
\left(10^{-6} \text { cgs }\right)\end{array}$ & $\begin{array}{c}\text { Composite }^{\mathrm{e}} \\
\text { density } \\
\left(\mathrm{g} / \mathrm{cm}^{3}\right)\end{array}$ & $\begin{array}{c}\mathrm{CaCO}_{3} \\
(\%)\end{array}$ & $\begin{array}{c}\text { Composite }^{f} \\
\mathrm{CaCO}_{3} \\
(\%)\end{array}$ & $\begin{array}{l}>150 \\
\mu \mathrm{m} \\
(\%)\end{array}$ & $\begin{array}{c}\text { C-org } \\
(\%)\end{array}$ & $\begin{array}{l}\delta^{18} \mathrm{O} \\
\left(\%_{00}\right)\end{array}$ \\
\hline $8 \mathrm{H}-7$ & 41 & 72.31 & 75.86 & 2.0590 & 3.33 & & & 1.40 & $\mathrm{k}_{1.025}$ & 76.03 & 76.03 & 3.1 & 1.294 & -0.990 \\
\hline $8 \mathrm{H}-7$ & 61 & 72.51 & 76.06 & 2.0650 & 3.33 & & & 1.02 & $\mathrm{k}_{1.052}$ & 78.84 & .78 .84 & 3.8 & 1.257 & -0.860 \\
\hline $721 \mathrm{~B}$ & & & 76.26 & 2.0710 & 3.33 & & & $\mathrm{k}_{0.70}$ & $\mathrm{k}_{1.025}$ & & $i_{77.41}$ & & & \\
\hline $721 \mathrm{~B}$ & & & 76.46 & 2.0770 & 3.33 & & & $\mathrm{k}_{0.72}$ & $\mathrm{k}_{1.005}$ & & 77.32 & & & \\
\hline $721 \mathrm{~B}$ & & & 76.66 & 2.0830 & 3.33 & & & $\mathrm{k}_{1.46}$ & $\mathrm{k}_{1.086}$ & & 74.29 & & & \\
\hline $9 \mathrm{H}-1$ & 1 & 72.51 & 76.76 & 2.0860 & 3.33 & & & $\mathrm{k}_{3.72}$ & $\mathrm{k}_{1.093}$ & 58.09 & i 65.01 & 0.7 & 1.749 & -0.360 \\
\hline $9 \mathrm{H}-1$ & 21 & 72.71 & 76.96 & 2.0920 & 3.33 & & & 3.50 & $\mathrm{k}_{1.133}$ & 69.84 & ${ }^{i} 65.91$ & 2.8 & 1.594 & \\
\hline $9 \mathrm{H}-1$ & 41 & 72.91 & 77.16 & 2.0980 & 3.33 & & & 3.06 & $\mathrm{k}_{1.046}$ & 66.25 & 66.25 & 2.0 & 1.624 & \\
\hline $9 \mathrm{H}-1$ & 61 & 73.11 & 77.36 & 2.1040 & 3.33 & & & 4.00 & 1.035 & 63.74 & 63.74 & 2.4 & 1.497 & -0.455 \\
\hline $9 \mathrm{H}-1$ & 81 & 73.31 & 77.56 & 2.1100 & 3.33 & & & 3.90 & 1.059 & 63.99 & 63.99 & & 1.703 & \\
\hline $9 \mathrm{H}-1$ & 101 & 73.51 & 77.76 & 2.1160 & 3.33 & & & 2.90 & 1.016 & 65.54 & 65.54 & 1.7 & 1.924 & -0.800 \\
\hline 9H-1 & 121 & 73.71 & 77.96 & 2.1220 & 3.08 & & & 1.80 & 1.085 & 70.87 & 70.87 & 2.6 & 1.744 & -1.090 \\
\hline $9 \mathrm{H}-1$ & 141 & 73.91 & 78.16 & 2.1290 & 3.08 & & & 1.04 & 0.954 & 66.09 & 66.09 & 1.7 & 1.489 & -0.940 \\
\hline $9 \mathrm{H}-2$ & 11 & 74.11 & 78.36 & 2.1350 & 3.33 & & & 1.20 & 0.893 & 70.96 & 70.96 & 3.4 & 1.493 & -0.935 \\
\hline $9 \mathrm{H}-2$ & 31 & 74.31 & 78.56 & 2.1410 & 3.33 & & & 2.26 & 0.993 & 68.19 & 68.19 & 4.7 & 1.506 & -0.710 \\
\hline $9 \mathrm{H}-2$ & 51 & 74.51 & 78.76 & 2.1470 & 3.33 & & & 4.32 & 1.070 & 60.69 & 60.69 & 3.2 & 1.315 & 0.200 \\
\hline $9 \mathrm{H}-2$ & 71 & 74.71 & 78.96 & 2.1530 & 3.33 & & & 3.84 & 1.035 & 62.90 & 62.90 & 1.0 & 1.692 & \\
\hline $9 \mathrm{H}-2$ & 91 & 74.91 & 79.16 & 2.1590 & 3.33 & & & 2.74 & 1.118 & 63.68 & 63.68 & 4.9 & 1.524 & -0.290 \\
\hline $9 \mathrm{H}-2$ & 111 & 75.11 & 79.36 & 2.1650 & 3.33 & & & 1.52 & 1.066 & 71.83 & 71.83 & 3.7 & 1.341 & -0.750 \\
\hline $9 \mathrm{H}-2$ & 131 & 75.31 & 79.56 & 2.1710 & 3.33 & & & 1.52 & 1.069 & 69.35 & 69.35 & 3.7 & 2.465 & -0.640 \\
\hline $9 \mathrm{H}-3$ & 1 & 75.51 & 79.76 & 2.1770 & 3.33 & & & 2.90 & 1.006 & 64.81 & 64.81 & 3.6 & 2.044 & -0.620 \\
\hline $9 \mathrm{H}-3$ & 21 & 75.71 & 79.96 & 2.1830 & 3.33 & & & 4.34 & 1.035 & 57.73 & 57.73 & 4.9 & 1.950 & \\
\hline $9 \mathrm{H}-3$ & 41 & 75.91 & 80.16 & 2.1890 & 3.33 & & & 4.34 & 1.117 & 58.49 & 58.49 & 1.4 & 1.761 & -0.530 \\
\hline $9 \mathrm{H}-3$ & 61 & 76.11 & 80.36 & 2.1950 & 3.33 & & & 3.68 & 1.023 & 63.98 & 63.98 & 4.3 & 1.768 & -0.450 \\
\hline $9 \mathrm{H}-3$ & 81 & 76.31 & 80.56 & 2.2010 & 3.08 & & & 4.44 & 1.012 & 60.26 & 60.26 & 3.1 & 1.235 & -0.200 \\
\hline $9 \mathrm{H}-3$ & 101 & 76.51 & 80.76 & 2.2080 & 3.08 & & & 7.06 & 1.132 & 45.50 & 45.50 & 1.0 & 1.947 & -0.940 \\
\hline $9 \mathrm{H}-3$ & 121 & 76.71 & 80.96 & 2.2140 & 3.33 & & & 2.12 & 1.105 & 71.59 & 71.59 & 0.8 & 2.027 & -1.350 \\
\hline $9 \mathrm{H}-3$ & 141 & 76.91 & 81.16 & 2.2200 & 3.33 & & & 3.42 & 1.075 & 60.88 & 60.88 & 1.5 & 1.713 & \\
\hline $9 \mathrm{H}-4$ & 11 & 77.11 & 81.36 & 2.2260 & 3.33 & & & 5.32 & 0.980 & 50.68 & 50.68 & 1.2 & 2.116 & \\
\hline $9 \mathrm{H}-4$ & 31 & 77.31 & 81.56 & 2.2320 & 3.33 & & & 5.76 & 1.077 & 0.06 & 55.65 & 1.8 & 1.712 & -0.880 \\
\hline $9 \mathrm{H}-4$ & 51 & 77.51 & 81.76 & 2.2380 & 3.33 & & & 5.84 & 1.029 & 47.65 & 47.65 & 1.1 & & -1.200 \\
\hline $9 \mathrm{H}-4$ & 71 & 77.71 & 81.96 & 2.2440 & 3.33 & & & 1.54 & 1.128 & 76.86 & 76.86 & 5.1 & 1.469 & -1.243 \\
\hline $9 \mathrm{H}-4$ & 91 & 77.91 & 82.16 & 2.2500 & 3.33 & & & 4.26 & 1.001 & 56.75 & 56.75 & 1.8 & 1.931 & -0.810 \\
\hline $9 \mathrm{H}-4$ & 111 & 78.11 & 82.36 & 2.2560 & 3.33 & & & 5.24 & 1.021 & 52.20 & 52.20 & 1.3 & 1.680 & -0.080 \\
\hline $9 \mathrm{H}-4$ & 131 & 78.31 & 82.56 & 2.2620 & 3.33 & & & 2.42 & 1.075 & 71.11 & 71.11 & 1.7 & 1.754 & -0.950 \\
\hline $9 \mathrm{H}-5$ & 1 & 78.51 & 82.76 & 2.2680 & 3.33 & & & 2.58 & 1.006 & 60.21 & 60.21 & 2.0 & 1.919 & -0.820 \\
\hline 9H-5 & 21 & 78.71 & 82.96 & 2.2740 & 3.33 & & & 3.66 & 1.056 & 65.00 & 65.00 & 1.8 & 1.654 & -1.240 \\
\hline 9H-5 & 41 & 78.91 & 83.16 & 2.2800 & 3.08 & & & 1.52 & 1.015 & 79.02 & 79.02 & 3.0 & 2.719 & -0.820 \\
\hline 9H-5 & 61 & 79.11 & 83.36 & 2.2870 & 3.08 & & & 3.40 & 1.054 & 65.69 & 65.69 & 2.8 & 1.728 & -1.190 \\
\hline 9H-5 & 81 & 79.31 & 83.56 & 2.2930 & 3.33 & & & 6.88 & 1.052 & 47.57 & 47.57 & 0.9 & 2.118 & \\
\hline 9H-5 & 101 & 79.51 & 83.76 & 2.2990 & 3.33 & & & 2.76 & 1.063 & 68.96 & 68.96 & 1.6 & 2.101 & -1.470 \\
\hline 9H-5 & 121 & 79.71 & 83.96 & 2.3050 & 3.33 & & & 4.46 & 0.950 & 55.36 & 55.36 & 1.2 & 2.739 & -1.140 \\
\hline $9 \mathrm{H}-5$ & 141 & 79.91 & 84.16 & 2.3110 & 3.33 & & & 3.88 & 1.043 & 63.86 & 63.86 & 1.1 & 2.284 & -0.890 \\
\hline $9 \mathrm{H}-6$ & 11 & 80.11 & 84.36 & 2.3170 & 3.33 & & & 4.64 & 1.060 & 58.73 & 58.73 & 2.4 & 1.662 & -0.560 \\
\hline $9 \mathrm{H}-6$ & 31 & 80.31 & 84.56 & 2.3230 & 3.33 & & & 5.42 & 1.164 & 53.23 & 53.23 & 1.1 & 2.636 & \\
\hline $9 \mathrm{H}-6$ & 51 & 80.51 & 84.76 & 2.3290 & 3.33 & & & 1.06 & 1.025 & 81.37 & 81.37 & 2.8 & 2.575 & -0.955 \\
\hline $9 \mathrm{H}-6$ & 71 & 80.71 & 84.96 & 2.3350 & 3.33 & & & 2.82 & 1.019 & 65.92 & 65.92 & 1.8 & 3.194 & \\
\hline $9 \mathrm{H}-6$ & 91 & 80.91 & 85.16 & 2.3410 & 3.33 & & & 5.70 & 1.136 & 50.36 & 50.36 & 0.5 & 2.559 & \\
\hline $9 \mathrm{H}-6$ & 111 & 81.11 & 85.36 & 2.3470 & 3.33 & & & 4.58 & 0.963 & 52.61 & 52.61 & 0.4 & 3.741 & \\
\hline $9 \mathrm{H}-6$ & 131 & 81.31 & 85.56 & 2.3530 & 3.33 & & & 2.14 & 1.052 & 67.00 & 67.00 & 1.2 & 2.697 & \\
\hline 9H-7 & 1 & 81.51 & 85.76 & 2.3590 & 3.08 & & & 2.92 & ${ }^{k} 0.911$ & 64.86 & 64.86 & 0.8 & 2.730 & \\
\hline $9 \mathrm{H}-7$ & 21 & 81.71 & 85.96 & 2.3660 & 3.08 & & & 2.96 & $k_{1.012}$ & 62.52 & 62.52 & 0.7 & 2.506 & \\
\hline $9 \mathrm{H}-7$ & 41 & 81.91 & 86.16 & 2.3720 & 3.33 & & & 3.30 & $\mathrm{k}_{1.086}$ & 62.24 & 62.24 & 0.7 & 2.256 & -0.720 \\
\hline \multirow[t]{6}{*}{$9 \mathrm{H}-7$} & 61 & 82.11 & 86.36 & 2.3780 & 3.46 & & & 2.02 & $k_{1.052}$ & 71.99 & 71.99 & 1.6 & 2.382 & -1.210 \\
\hline & & & 86.61 & 2.3850 & 3.46 & & & $k_{3.76}$ & $k_{0.998}$ & & 60.59 & & & \\
\hline & & & 86.81 & 2.3910 & 3.33 & & & $\mathrm{k}_{3.04}$ & ${ }^{\mathrm{k}} 0.958$ & & ${ }^{\mathrm{i}} 65.03$ & & & \\
\hline & & & 87.01 & 2.3970 & 3.33 & & & $k_{2.52}$ & ${ }^{k} 0.965$ & & 68.24 & & & \\
\hline & & & 87.21 & 2.4030 & 3.08 & & & $k_{2.84}$ & $k_{0.971}$ & & ${ }^{i} 66.27$ & & & \\
\hline & & & 87.41 & 2.4100 & 3.08 & & & $k_{2.62}$ & ${ }^{\mathrm{k}} 0.944$ & & ${ }^{\mathrm{i}} 67.63$ & & & \\
\hline $10 \mathrm{H}-1$ & 1 & 82.71 & 87.61 & 2.4160 & 3.33 & & & $k_{1.50}$ & $\mathrm{k}_{1.019}$ & 59.06 & 74.54 & 1.2 & 2.288 & -1.040 \\
\hline $10 \mathrm{H}-1$ & 21 & 82.91 & 87.81 & 2.4220 & 3.33 & & & 2.76 & 0.985 & 69.29 & 66.76 & 1.0 & 2.908 & \\
\hline $10 \mathrm{H}-1$ & 41 & 83.11 & 88.01 & 2.4280 & 3.33 & & & 2.96 & 1.064 & 68.84 & ${ }^{\mathrm{i}} 65.53$ & 1.2 & 2.986 & \\
\hline $10 \mathrm{H}-1$ & 61 & 83.31 & 88.21 & 2.4340 & 3.33 & & & 2.58 & 0.993 & 68.65 & 68.65 & 0.9 & 2.375 & \\
\hline $10 \mathrm{H}-1$ & 81 & 83.51 & 88.41 & 2.4400 & 3.33 & & & 1.92 & 0.944 & 72.01 & 72.01 & 0.9 & 2.233 & -1.110 \\
\hline $10 \mathrm{H}-1$ & 101 & 83.71 & 88.61 & 2.4460 & 3.33 & & & 2.44 & 0.954 & 69.09 & 69.09 & 0.8 & 2.769 & -1.220 \\
\hline $10 \mathrm{H}-1$ & 121 & 83.91 & 88.81 & 2.4520 & 3.33 & & & 3.46 & 1.024 & 66.94 & 66.94 & 1.6 & 2.720 & -1.210 \\
\hline $10 \mathrm{H}-1$ & 141 & 84.11 & 89.01 & 2.4580 & 3.33 & & & 3.58 & 0.975 & 60.70 & 60.70 & 0.8 & 3.112 & \\
\hline $10 \mathrm{H}-2$ & 11 & 84.31 & 89.21 & 2.4640 & 3.33 & & & 3.12 & 0.891 & 64.61 & 64.61 & 1.0 & 2.528 & \\
\hline $10 \mathrm{H}-2$ & 31 & 84.51 & 89.41 & 2.4700 & 2.67 & & & 3.10 & 0.993 & 66.55 & 66.55 & 1.1 & 2.791 & \\
\hline $10 \mathrm{H}-2$ & 51 & 84.71 & 89.61 & 2.4790 & 2.22 & & & 4.20 & 0.944 & 57.04 & 57.04 & 1.0 & 3.142 & \\
\hline $10 \mathrm{H}-2$ & 71 & 84.91 & 89.81 & 2.4880 & 2.22 & & & 3.62 & 1.009 & 61.29 & 61.29 & 0.8 & 2.649 & \\
\hline $10 \mathrm{H}-2$ & 91 & 85.11 & 90.01 & 2.4970 & 2.35 & & & 3.48 & 0.934 & 59.38 & 59.38 & 0.5 & 3.362 & \\
\hline $10 \mathrm{H}-2$ & 111 & 85.31 & 90.21 & 2.5050 & 2.35 & & & 4.16 & 0.998 & 58.19 & 58.19 & 0.6 & 2.939 & \\
\hline $10 \mathrm{H}-2$ & 131 & 85.51 & 90.41 & 2.5140 & 2.22 & & & 2.04 & 0.951 & 70.57 & 70.57 & 0.7 & 2.631 & \\
\hline $10 \mathrm{H}-3$ & 1 & 85.71 & 90.61 & 2.5230 & 2.35 & & & 4.16 & 1.029 & 59.74 & 59.74 & 0.7 & 3.271 & \\
\hline $10 \mathrm{H}-3$ & 21 & 85.91 & 90.81 & 2.5310 & 2.35 & & & 7.24 & 1.042 & 45.59 & 45.59 & 0.3 & 4.208 & \\
\hline
\end{tabular}


Appendix (continued).

\begin{tabular}{|c|c|c|c|c|c|c|c|c|c|c|c|c|c|c|}
\hline $\begin{array}{l}\text { Core, } \\
\text { section }\end{array}$ & $\begin{array}{l}\text { Section } \\
\text { depth } \\
\text { (cm) }\end{array}$ & $\begin{array}{l}\text { ODP } \\
\text { depth } \\
\text { (m) }\end{array}$ & $\begin{array}{l}\text { Composite }^{a} \\
\text { depth } \\
\text { (m) }\end{array}$ & $\begin{array}{l}\text { Ship b } \\
\text { age } \\
\text { (m.y.) }\end{array}$ & $\begin{array}{c}\text { Ship } \\
\text { sed. rate } \\
\text { (cm/k.y.) }\end{array}$ & $\begin{array}{l}\text { Isotope } \\
\text { age } \\
\text { (m.y.) }\end{array}$ & $\begin{array}{l}\text { Isotope } \\
\text { sed. rate } \\
\text { (cm/k.y.) }\end{array}$ & $\begin{array}{l}\text { Composite }^{\mathrm{d}} \\
\text { susceptibility } \\
\left(10^{-6} \mathrm{cgs}\right)\end{array}$ & $\begin{array}{c}\text { Composite }^{\mathrm{e}} \\
\text { density } \\
\left(\mathrm{g} / \mathrm{cm}^{3}\right)\end{array}$ & $\begin{array}{c}\mathrm{CaCO}_{3} \\
(\%)\end{array}$ & $\begin{array}{c}\text { Composite }^{f} \\
\mathrm{CaCO}_{3} \\
(\%)\end{array}$ & $\begin{array}{c}>150 \\
\mu \mathrm{m} \\
(\%)\end{array}$ & $\begin{array}{c}\text { C-org } \\
(\%)\end{array}$ & $\begin{array}{l}\delta^{18} \mathrm{O} \\
(\% 0)\end{array}$ \\
\hline $10 \mathrm{H}-3$ & 41 & 86.11 & 91.01 & 2.5400 & 2.22 & & & 4.78 & 0.923 & 56.40 & 56.40 & 0.4 & 2.478 & \\
\hline $10 \mathrm{H}-3$ & 61 & 86.31 & 91.21 & 2.5490 & 2.35 & & & 3.06 & 0.997 & 69.54 & 69.54 & 1.1 & 1.816 & \\
\hline $10 \mathrm{H}-3$ & 81 & 86.51 & 91.41 & 2.5570 & 2.35 & & & 4.34 & 0.918 & 56.74 & 56.74 & 0.4 & 2.228 & \\
\hline $10 \mathrm{H}-3$ & 101 & 86.71 & 91.61 & 2.5660 & 2.22 & & & 5.12 & 0.984 & 53.88 & 53.88 & 0.2 & 3.005 & \\
\hline $10 \mathrm{H}-3$ & 121 & 86.91 & 91.81 & 2.5750 & 2.35 & & & 2.84 & 0.978 & 73.40 & 73.40 & 1.1 & 1.341 & \\
\hline $10 \mathrm{H}-3$ & 141 & 87.11 & 92.01 & 2.5830 & 2.35 & & & 4.28 & 0.955 & 57.83 & 57.83 & 0.4 & 2.799 & \\
\hline $10 \mathrm{H}-4$ & 11 & 87.31 & 92.21 & 2.5920 & 2.22 & & & 4.64 & 0.966 & 56.03 & 56.03 & 0.5 & & \\
\hline $10 \mathrm{H}-4$ & 31 & 87.51 & 92.41 & 2.6010 & 2.35 & & & 2.40 & 0.998 & 73.87 & 73.87 & 1.1 & & \\
\hline $10 \mathrm{H}-4$ & 51 & 87.71 & 92.61 & 2.6090 & 2.35 & & & 3.56 & 0.989 & 65.40 & 65.40 & 0.5 & & \\
\hline $10 \mathrm{H}-4$ & 71 & 87.91 & 92.81 & 2.6180 & 2.22 & & & 4.68 & 1.006 & 0.06 & 58.50 & 0.4 & & \\
\hline $10 \mathrm{H}-4$ & 91 & 88.11 & 93.01 & 2.6270 & 2.22 & & & 4.42 & 0.997 & 60.32 & 60.32 & 0.4 & & \\
\hline $10 \mathrm{H}-4$ & 111 & 88.31 & 93.21 & 2.6360 & 2.35 & & & 4.00 & 1.040 & 61.66 & 61.66 & 0.5 & 2.758 & \\
\hline $10 \mathrm{H}-4$ & 131 & 88.51 & 93.41 & 2.6440 & 2.35 & & & 6.60 & 1.028 & 48.46 & 48.46 & 0.3 & 3.393 & \\
\hline $10 \mathrm{H}-5$ & 1 & 88.71 & 93.61 & 2.6530 & 2.22 & & & 6.36 & 0.878 & 49.66 & 49.66 & 0.3 & 2.660 & \\
\hline $10 \mathrm{H}-5$ & 21 & 88.91 & 93.81 & 2.6620 & 2.35 & & & 2.72 & 1.086 & 70.84 & 70.84 & 1.3 & 1.904 & \\
\hline $10 \mathrm{H}-5$ & 41 & 89.11 & 94.01 & 2.6700 & 2.35 & & & 4.72 & 1.086 & 64.94 & 64.94 & 0.8 & 2.444 & \\
\hline $10 \mathrm{H}-5$ & 61 & 89.31 . & 94.21 & 2.6790 & 2.22 & & & 7.88 & 1.058 & 40.31 & 40.31 & 0.2 & 3.771 & \\
\hline $10 \mathrm{H}-5$ & 81 & 89.51 & 94.41 & 2.6880 & 2.35 & & & 6.22 & 1.113 & 53.87 & 53.87 & 0.5 & 1.946 & \\
\hline $10 \mathrm{H}-5$ & 101 & 89.71 & 94.61 & 2.6960 & 2.35 & & & 3.62 & 1.056 & 65.73 & 65.73 & 0.7 & 2.485 & \\
\hline $10 \mathrm{H}-5$ & 121 & 89.91 & 94.81 & 2.7050 & 2.22 & & & 4.34 & 1.005 & 55.75 & 55.75 & 0.4 & 3.760 & \\
\hline $10 \mathrm{H}-5$ & 141 & 90.11 & 95.01 & 2.7140 & 2.35 & & & 4.00 & 1.005 & 62.66 & 62.66 & 0.5 & 1.532 & \\
\hline $10 \mathrm{H}-6$ & 11 & 90.31 & 95.21 & 2.7220 & 2.35 & & & 1.86 & 1.000 & 76.63 & 76.63 & 2.0 & 1.350 & \\
\hline $10 \mathrm{H}-6$ & 31 & 90.51 & 95.41 & 2.7310 & 2.22 & & & 2.88 & 1.089 & 70.38 & 70.38 & 0.6 & 2.071 & \\
\hline $10 \mathrm{H}-6$ & 51 & 90.71 & 95.61 & 2.7400 & 2.22 & & & 4.38 & 1.093 & 61.05 & 61.05 & 0.5 & 2.773 & \\
\hline $10 \mathrm{H}-6$ & 71 & 90.91 & 95.81 & 2.7490 & 2.35 & & & 4.50 & 1.082 & 60.83 & 60.83 & 0.2 & 2.842 & \\
\hline $10 \mathrm{H}-6$ & 91 & 91.11 & 96.01 & 2.7570 & 2.35 & & & 3.44 & 0.984 & 65.55 & 65.55 & 0.5 & 2.238 & \\
\hline $10 \mathrm{H}-6$ & 111 & 91.31 & 96.21 & 2.7660 & 2.22 & & & 2.94 & 1.039 & 74.35 & 74.35 & 2.1 & 1.359 & \\
\hline $10 \mathrm{H}-6$ & 131 & 91.51 & 96.41 & 2.7750 & 2.35 & & & 3.98 & 1.081 & 64.93 & 64.93 & 0.5 & 2.430 & \\
\hline $10 \mathrm{H}-7$ & 1 & 91.71 & 96.61 & 2.7830 & 2.35 & & & 4.56 & $\mathrm{k}_{1.005}$ & 58.54 & 58.54 & 0.6 & 2.994 & \\
\hline $10 \mathrm{H}-7$ & 21 & 91.91 & 96.81 & 2.7920 & 2.22 & & & 3.84 & $k_{0.904}$ & 65.30 & 65.30 & 0.7 & 2.402 & \\
\hline $10 \mathrm{H}-7$ & 41 & 92.11 & 97.01 & 2.8010 & 2.35 & & & 4.36 & ${ }^{k} 0.911$ & 64.58 & 64.58 & 0.8 & 2.177 & \\
\hline $10 \mathrm{H}-7$ & 61 & 92.31 & 97.21 & 2.8090 & 2.37 & & & 6.16 & ${ }^{k} 0.944$ & 46.58 & 46.58 & 0.2 & 4.727 & \\
\hline $11 X-1$ & 1 & 91.91 & 97.46 & 2.8200 & 2.25 & & & $k_{3} .06$ & $\mathrm{k}_{1.093}$ & 62.34 & 62.34 & 1.1 & 1.724 & \\
\hline $11 X-1$ & 21 & 92.11 & 97.66 & 2.8290 & 2.22 & & & $k_{3.66}$ & $k_{1.039}$ & 75.83 & 75.83 & 2.1 & 1.605 & \\
\hline $11 X-1$ & 41 & 92.31 & 97.86 & 2.8380 & 2.35 & & & $\mathrm{~h}_{2.40}$ & 1.048 & 74.62 & 74.62 & 1.7 & 1.130 & \\
\hline $11 X-1$ & 61 & 92.51 & 98.06 & 2.8460 & 2.35 & & & $\mathrm{~h}_{2.60}$ & 0.912 & 69.74 & 69.74 & 0.6 & 2.221 & \\
\hline $11 X-1$ & 81 & 92.71 & 98.26 & 2.8550 & 2.22 & & & $\mathrm{~h}_{2.64}$ & 0.965 & 69.64 & 69.64 & 0.8 & 1.932 & \\
\hline $11 X-1$ & 101 & 92.91 & 98.46 & 2.8640 & 2.35 & & & $\mathrm{~h}_{3.12}$ & 0.977 & 69.39 & 69.39 & 0.8 & 1.729 & \\
\hline $11 X-1$ & 121 & 93.11 & 98.66 & 2.8720 & 2.35 & & & $\mathrm{~h}_{4.08}$ & 0.905 & 69.22 & 69.22 & 0.5 & 2.434 & \\
\hline $11 X-1$ & 141 & 93.31 & 98.86 & 2.8810 & 2.22 & & & $\mathrm{~h}_{3.64}$ & 0.915 & 57.24 & 57.24 & 0.4 & 2.859 & \\
\hline $11 X-2$ & 11 & 93.51 & 99.06 & 2.8900 & 2.35 & & & $h_{4.12}$ & 0.907 & 62.80 & 62.80 & 0.7 & 2.135 & \\
\hline $11 X-2$ & 31 & 93.71 & 99.26 & 2.8980 & 2.35 & & & 3.86 & 0.943 & 71.50 & 71.50 & 1.4 & 1.016 & \\
\hline $11 X-2$ & 51 & 93.91 & 99.46 & 2.9070 & 2.22 & & & 4.44 & 0.971 & 65.65 & 65.65 & 0.5 & 2.352 & \\
\hline $11 X-2$ & 71 & 94.11 & 99.66 & 2.9160 & 2.22 & & & 3.96 & 0.935 & 61.57 & 61.57 & 1.0 & 1.598 & -0.830 \\
\hline $11 X-2$ & 91 & 94.31 & 99.86 & 2.9250 & 2.59 & & & 4.38 & 1.036 & 62.88 & 62.88 & 0.5 & 1.982 & \\
\hline $11 \times-2$ & 111 & 94.51 & 100.06 & 2.9330 & 2.59 & & & 3.98 & 0.951 & 60.67 & 60.67 & 0.5 & 2.871 & \\
\hline $11 X-2$ & 131 & 94.71 & 100.26 & 2.9420 & 2.22 & & & 3.34 & 0.911 & 66.82 & 66.82 & 0.4 & 3.389 & \\
\hline $11 X-3$ & 1 & 94.91 & 100.46 & 2.9510 & 2.35 & & & 4.74 & 0.820 & 56.14 & 56.14 & 0.3 & 4.376 & \\
\hline $11 X-3$ & 21 & 95.11 & 100.66 & 2.9590 & 2.35 & & & 3.50 & 0.853 & 67.52 & 67.52 & 0.3 & 3.052 & \\
\hline $11 X-3$ & 41 & 95.31 & 100.86 & 2.9680 & 2.22 & & & 3.68 & 0.881 & 71.67 & 71.67 & 0.7 & 1.447 & \\
\hline $11 X-3$ & 61 & 95.51 & 101.06 & 2.9770 & 2.35 & & & 3.88 & 0.969 & 64.12 & 64.12 & 0.5 & 2.491 & \\
\hline $11 X-3$ & 81 & 95.71 & 101.26 & 2.9850 & 2.35 & & & 3.26 & 0.911 & 67.19 & 67.19 & 0.6 & 1.947 & \\
\hline $11 X-3$ & 101 & 95.91 & 101.46 & 2.9940 & 2.22 & & & 4.72 & 1.035 & 57.66 & 57.66 & 0.5 & 1.926 & \\
\hline $11 X-3$ & 121 & 96.11 & 101.66 & 3.0030 & 2.35 & & & 2.98 & 0.857 & 64.43 & 64.43 & 2.3 & 1.085 & -1.370 \\
\hline $11 X-3$ & 141 & 96.31 & 101.86 & 3.0110 & 2.35 & & & 3.82 & 1.063 & 63.72 & 63.72 & 1.8 & 1.322 & -1.540 \\
\hline $11 X-4$ & 11 & 96.51 & 102.06 & 3.0200 & 2.22 & & & 4.82 & 0.971 & 59.36 & 59.36 & 1.1 & 1.041 & ${ }^{j}-0.900$ \\
\hline $11 X-4$ & 31 & 96.71 & 102.26 & 3.0290 & 2.22 & & & 2.36 & 1.104 & 75.61 & 75.61 & 1.5 & 0.984 & -1.450 \\
\hline $11 X-4$ & 51 & 96.91 & 102.46 & 3.0380 & 2.35 & & & 2.36 & 1.016 & 74.79 & 74.79 & 1.1 & 1.966 & -2.080 \\
\hline $11 X-4$ & 71 & 97.11 & 102.66 & 3.0460 & 2.35 & & & 3.26 & 1.023 & 66.95 & 66.95 & 0.8 & 1.792 & -1.440 \\
\hline $11 X-4$ & 91 & 97.31 & 102.86 & 3.0550 & 2.22 & & & 2.80 & 1.028 & 69.88 & 69.88 & 1.2 & 1.218 & -1.390 \\
\hline \multirow[t]{16}{*}{$11 X-4$} & 111 & 97.51 & 103.06 & 3.0640 & 2.11 & & & 2.54 & 1.052 & 67.68 & 72.80 & 1.5 & 1.025 & -1.760 \\
\hline & & & 103.31 & 3.0740 & 2.11 & & & $k_{3.22}$ & $k_{0.938}$ & & 68.55 & & & \\
\hline & & & 103.51 & 3.0830 & 2.22 & & & $\mathrm{k}_{3.88}$ & $k_{0.958}$ & & i 64.42 & & & \\
\hline & & & 103.71 & 3.0920 & 2.22 & & & $k_{2.66}$ & $\mathrm{k}_{1.005}$ & & 72.05 & & & \\
\hline & & & 103.91 & 3.1010 & 2.35 & & & $\mathrm{k}_{3.05}$ & $\mathrm{k}_{1.019}$ & & ${ }^{\mathrm{i}} 69.61$ & & & \\
\hline & & & 104.11 & 3.1090 & 2.35 & & & $k_{4.04}$ & $\mathrm{k}_{0.958}$ & & ${ }^{\mathrm{i}} 63.42$ & & & \\
\hline & & & 104.31 & 3.1180 & 2.22 & & & $\mathrm{k}_{3.20}$ & $\mathrm{k}_{0.951}$ & & i 68.67 & & & \\
\hline & & & 104.51 & 3.1270 & 2.35 & & & $k_{1.40}$ & ${ }^{k} 0.998$ & & i 79.93 & & & \\
\hline & & & 104.71 & 3.1350 & 2.35 & & & $\mathrm{k}_{1.52}$ & $k_{0.951}$ & & $i_{79.18}$ & & & \\
\hline & & & 104.91 & 3.1440 & 2.22 & & & $\mathrm{k}_{2.04}$ & $\mathrm{k}_{0.918}$ & & '75.93 & & & \\
\hline & & & 105.11 & 3.1530 & 2.35 & & & $\mathrm{k}_{3.10}$ & $\mathrm{k}_{0.998}$ & & $\mathrm{i}_{69.30}$ & & & \\
\hline & & & 105.31 & 3.1610 & 2.35 & & & $\mathrm{k}_{3.12}$ & $k_{0.971}$ & & $\mathrm{i}_{69.17}$ & & & \\
\hline & & & 105.51 & 3.1700 & 2.22 & & & $\mathrm{k}_{2.74}$ & $\mathrm{k}_{0.998}$ & & 71.55 & & & \\
\hline & & & 105.71 & 3.1790 & 2.35 & & & $h_{3.10}$ & $h_{0.971}$ & & $\mathrm{i}_{69.30}$ & & & \\
\hline & & & 105.91 & 3.1870 & 2.35 & & & $h_{4.76}$ & $\mathrm{~h}_{1.012}$ & & ${ }^{i} 58.91$ & & & \\
\hline & & & 106.11 & 3.1960 & 2.22 & & & $h_{3.12}$ & $h_{0.985}$ & & ${ }^{\mathrm{i}} 69.17$ & & & \\
\hline
\end{tabular}


VARIATIONS IN CALCIUM CARBONATE, ORGANIC CARBON, AND OPAL

Appendix (continued).

\begin{tabular}{|c|c|c|c|c|c|c|c|c|c|c|c|c|c|c|}
\hline $\begin{array}{l}\text { Core, } \\
\text { section }\end{array}$ & $\begin{array}{l}\text { Section } \\
\text { depth } \\
\text { (cm) }\end{array}$ & $\begin{array}{l}\text { ODP } \\
\text { depth } \\
\text { (m) }\end{array}$ & $\begin{array}{l}\text { Composite }^{\mathrm{a}} \\
\text { depth } \\
\text { (m) }\end{array}$ & $\begin{array}{l}\text { Ship }^{b} \\
\text { age } \\
\text { (m.y.) }\end{array}$ & $\begin{array}{c}\text { Ship } \\
\text { sed. rate } \\
\text { (cm/k.y.) }\end{array}$ & $\begin{array}{l}\text { Isotope }{ }^{c} \\
\text { age } \\
\text { (m.y.) }\end{array}$ & $\begin{array}{l}\text { Isotope } \\
\text { sed. rate } \\
\text { (cm/k.y.) }\end{array}$ & $\begin{array}{l}\text { Composite }^{d} \\
\text { susceptibility } \\
\left(10^{-6} \mathrm{cgs}\right)\end{array}$ & $\begin{array}{c}\text { Composite }^{e} \\
\text { density } \\
\left(\mathrm{g} / \mathrm{cm}^{3}\right)\end{array}$ & $\begin{array}{c}\mathrm{CaCO}_{3} \\
(\%)\end{array}$ & $\begin{array}{c}\text { Composite }^{f} \\
\mathrm{CaCO}_{3} \\
(\%)\end{array}$ & $\begin{array}{c}>150 \\
\mu \mathrm{m} \\
(\%)\end{array}$ & $\begin{array}{c}\text { C-org } \\
(\%)\end{array}$ & $\begin{array}{l}\delta^{18} \mathrm{O} \\
\left(\%_{0}\right)\end{array}$ \\
\hline & & & 106.31 & 3.2050 & 2.22 & & & $\mathrm{~b}_{2.24}$ & $\mathrm{~h}_{0} 0.958$ & & $i_{74.68}$ & & & \\
\hline & & & 106.51 & 3.2140 & 2.35 & & & $\mathrm{~h}_{4.34}$ & $\mathrm{~h}_{0} 0.897$ & & 61.54 & & & \\
\hline & & & 106.71 & 3.2220 & 2.35 & & & $\mathrm{~b}_{3.50}$ & $h_{1.073}$ & & ${ }^{\mathrm{i}} 66.79$ & & & \\
\hline & & & 106.91 & 3.2310 & 2.22 & & & $\mathrm{~b}_{2.96}$ & $\mathrm{~h}_{0.965}$ & & 70.17 & & & \\
\hline & & & 107.11 & 3.2400 & 2.35 & & & $\mathrm{~h}_{3.02}$ & $h_{0} 0.985$ & & i 69.80 & & & \\
\hline $12 X-1$ & 1 & 101.51 & 107.31 & 3.2480 & 2.35 & & & $\mathrm{~h}_{1.18}$ & $\mathrm{~h}_{1.012}$ & 67.51 & $\mathrm{i} 81.31$ & 2.2 & 1.192 & -0.930 \\
\hline $12 X-1$ & 21 & 101.71 & 107.51 & 3.2570 & 2.22 & & & $\mathrm{~b}_{2.42}$ & 1.028 & 72.85 & $\mathrm{i}_{73.55}$ & 0.9 & 0.992 & -0.940 \\
\hline $12 X-1$ & 41 & 101.91 & 107.71 & 3.2660 & 2.35 & & & $\mathrm{~b}_{2.88}$ & 1.054 & 76.03 & ${ }^{\mathrm{i}} 70.67$ & 1.8 & 1.031 & -1.010 \\
\hline $12 X-1$ & 61 & 102.11 & 107.91 & 3.2740 & 2.35 & & & $\mathrm{~h}_{1.94}$ & 1.069 & 73.16 & $i_{76.55}$ & 1.7 & 1.007 & -0.970 \\
\hline $12 X-1$ & 81 & 102.31 & 108.11 & 3.2830 & 2.22 & & & $h_{1.86}$ & 1.073 & 72.03 & $i_{77.05}$ & 1.3 & 1.064 & -0.970 \\
\hline $12 \mathrm{X}-1$ & 101 & 102.51 & 108.31 & 3.2920 & 2.35 & & & 2.60 & 1.025 & 76.67 & ${ }^{i} 72.42$ & 2.5 & 0.868 & -1.170 \\
\hline $12 X-1$ & 121 & 102.71 & 108.51 & 3.3000 & 2.35 & & & 1.80 & 0.997 & 78.48 & 78.48 & 2.6 & 1.133 & -1.505 \\
\hline $12 X-1$ & 141 & 102.91 & 108.71 & 3.3090 & 2.22 & & & 2.20 & 1.060 & 75.43 & 75.43 & 2.5 & 0.957 & -1.540 \\
\hline $12 X-2$ & 11 & 103.11 & 108.91 & 3.3180 & 2.22 & & & 3.00 & 1.006 & 72.58 & 72.58 & 1.1 & 1.586 & ${ }^{j}-0.690$ \\
\hline $12 X-2$ & 31 & 103.31 & 109.11 & 3.3270 & 2.35 & & & 3.08 & 1.044 & 72.98 & 72.98 & 0.8 & 1.556 & -1.100 \\
\hline $12 X-2$ & 51 & 103.51 & 109.31 & 3.3350 & 2.35 & & & 2.32 & 1.093 & 74.02 & 74.02 & 2.6 & 1.754 & -1.130 \\
\hline $12 X-2$ & 71 & 103.71 & 109.51 & 3.3440 & 2.22 & & & 3.52 & 1.083 & 68.78 & 68.78 & 0.9 & 1.038 & \\
\hline $12 X-2$ & 91 & 103.91 & 109.71 & 3.3530 & 2.35 & & & 4.60 & 1.081 & 61.21 & 61.21 & 0.7 & 1.380 & \\
\hline $12 \times-2$ & 111 & 104.11 & 109.91 & 3.3610 & 2.35 & & & 2.34 & 1.029 & 75.50 & 75.50 & 1.6 & 0.997 & -1.300 \\
\hline $12 X-2$ & 131 & 104.31 & 110.11 & 3.3700 & 2.22 & & & 1.32 & 1.087 & 79.84 & 79.84 & 2.3 & 1.008 & -1.395 \\
\hline $12 X-3$ & 1 & 104.51 & 110.31 & 3.3790 & 2.35 & & & 2.28 & 1.008 & 71.41 & 71.41 & 0.7 & 1.821 & \\
\hline $12 X-3$ & 21 & 104.71 & 110.51 & 3.3870 & 2.35 & & & 2.96 & 1.058 & 72.38 & 72.38 & 2.2 & 1.523 & \\
\hline $12 X-3$ & 41 & 104.91 & 110.71 & 3.3960 & 2.22 & & & 4.30 & 1.066 & 59.82 & 59.82 & 0.8 & 1.608 & \\
\hline $12 X-3$ & 61 & 105.11 & 110.91 & 3.4050 & 2.35 & & & 1.40 & 1.017 & 73.86 & 73.86 & 3.2 & 0.833 & -1.630 \\
\hline $12 X-3$ & 81 & 105.31 & 111.11 & 3.4130 & 2.35 & & & 1.74 & 1.013 & 77.82 & 77.82 & 3.7 & 0.721 & -1.265 \\
\hline $12 X-3$ & 101 & 105.51 & 111.31 & 3.4220 & 2.22 & & & 3.68 & 1.059 & 62.41 & 62.41 & 1.2 & 0.627 & \\
\hline
\end{tabular}

a Composite depth below seafloor based on Hole 722B data with patches from Holes 722A and 721B.

b Ages based on magnetic datums recognized in Hole 722B.

c Ages based on oxygen isotope chronostratigraphy of Imbrie et al. (1984) and Ruddiman et al. (1989).

d Composite magnetic susceptibility section with missing and suspect intervals obtained from Holes 722A and 721B with preference given to Hole 721B data. Original 5$\mathrm{cm}$-spaced data were sampled at a $20-\mathrm{cm}$ spacing using linear interpolation.

e Composite dry bulk density data with missing data obtained from Holes 722A and 721B. See text for conversion of GRAPE data to dry bulk density. Original 1.8-cmspaced GRAPE data were sampled at a $20-\mathrm{cm}$ interval using linear interpolation.

${ }^{f}$ Composite $\mathrm{CaCO}_{3}$ data for Hole 722B.

8 Value divided by two when plotted.

h Spliced data from Hole $722 \mathrm{~A}$.

${ }^{\mathrm{i}}$ Values derived from regression of magnetic susceptibility and $100-\mathrm{CaCO}_{3}$ for 10 samples above and 10 below data gap. The value at $5.54 \mathrm{~m}$ is based on a regression of 6 samples above and 6 below $5.54 \mathrm{~m}$.

${ }^{j}$ Sample generated low gas volumes during analysis. Data are suspect.

K Spliced data from Hole 721B.

${ }^{1}$ Concentrations at 24.91 and $25.31 \mathrm{~m}$ (ODP depth) switched to provide a match between $100-\mathrm{CaCO}_{3}$ and magnetic susceptibility. 